$\frac{\text { PNL-10717 }}{\text { Part } 1 \text { of } 2}$

\title{
A Review of Information for Managing Aging in Nuclear Power Plants
}

Compiled by W. C. Morgan and J. V. Livingston

September 1995

Prepared for

Division of Engineering Technology

Office of Nuclear Regulatory Research

U.S. Nuclear Regulatory Commission

under a Related Services Agreement with the

U.S. Department of Energy

under Contract DE-AC06-76RLO 1830

NRC JOBCODE B-2865

Pacific Northwest Laboratory

Operated for the U.S. Department of Energy

by Battelle Memorial Institute 
$\therefore$

i)

ato

\section{DISCLAIMER}

This report was prepared as an account of work sponsored by an agency of the United States Covernment. Neither the United States Covernment nor any agency thereof, nor Battelle Memorial Institute, nor any of their employees, makes any warranty, expressed or implied, or assumes any legal liability or responsibility for the accuracy, completeness, or usefulnessofany information, apparatus, product, or process disclosed, or represents that its use woald not infringe privately owned rights. Referenceherein to any specific commercial product, process, or serviceby trade name, trademark, manufacturer, or otherwisedoes not necessarily constitute or imply its endorsement, recommendation, or favoring by the United States Government or any agency thereof, or Battelle Memorial Institute. The views and opinions of authors expressed herein do not necessarily state or reflect those of the United States Government or any agency thereof.

\author{
PACIFIC NORTHWEST LABORATORY \\ operatedby \\ BATTELLE MEMORIAL INSTITUTE \\ for the \\ UNITED STATES DEPARTMENT OF ENERGY \\ under Contract DE-AC06-76RLO 1830
}

\section{LIMITED DISTRIBUTION NOTICE}

This document copy, since it is transmittedin advance of patent clearance, is made available in confidence solely for use in periormance of work under contracts with the U.S. Departmentof Energy. This document is not to be published nor its contents otherwise disseminated or used forpurposes otherthan specifiedabovebeforepatent approval for such release or use has been secured, upon request, from Intellectual Property Services, Pacific Northwest Labol atory, Richland, Washington 99352. 


\section{A Review of Information for Managing Aging in Nuclear Power Plants}

Compiled by W. C. Morgan and J. V. Livingston

September 1995

Prepared for

Division of Engineering Technology

Office of Nuclear Regulatory Research

U.S. Nuclear Regulatory Commission under a Related Services Agreement with the U.S. Department of Energy under Contract DE-AC06-76RLO 1830 NRC JOB CODE B-2865

Pacific Northwest Laboratory

Richland, Washington 99352 


\begin{abstract}
Age related degradation effects in safety related systems of nuclear power plants should be managed to prevent safety margins from eroding below the acceptable limits provided in plant design bases. The Nuclear Plant Aging Research (NPAR) Program, conducted under the auspices of the U.S. Nuclear Regulatory Commission (NRC), Office of Nuclear Regulatory Research, and other related aging management programs are developing technical information on managing aging. The aging management process central to these efforts consists of three key elements: 1) selecting structures, systems, and components (SSCs) in which aging should be controlled; 2) understanding the mechanisms and rates of degradation in these SSCs; and 3) managing degradation through effective inspection, surveillance, condition monitoring, trending, record keeping, maintenance, refurbishment, replacement, and adjustments in the operating environment and service conditions. This document concisely reviews and integrates information developed under the NPAR Program and other aging management studies and other available information related to understanding and managing age-related degradation effects and provides specific references to more comprehensive information on the same subjects.
\end{abstract}




\section{Contents}

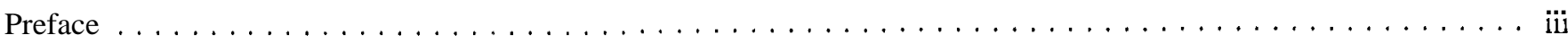

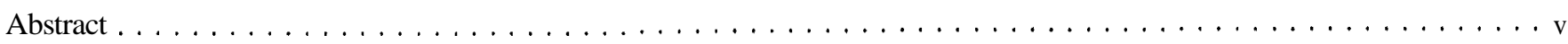

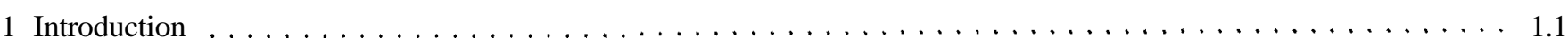

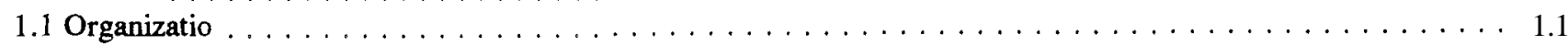

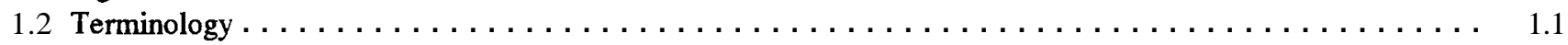

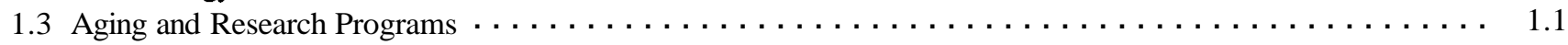



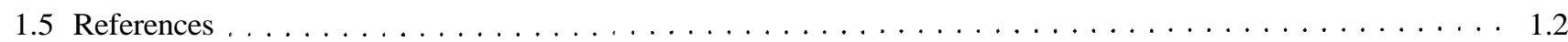

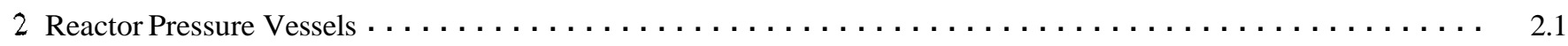

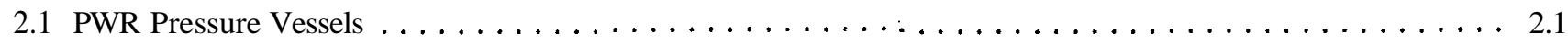

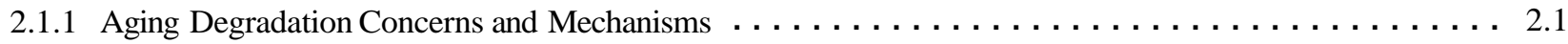

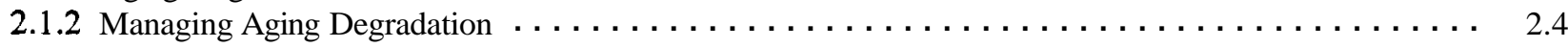

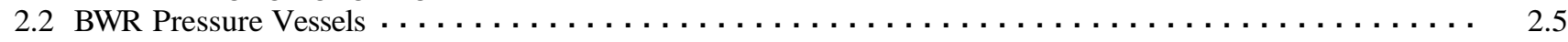

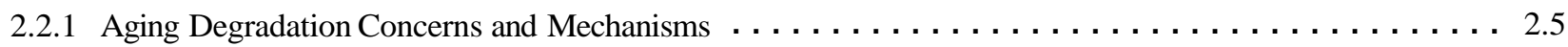

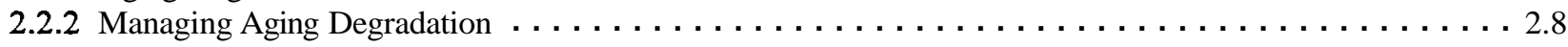

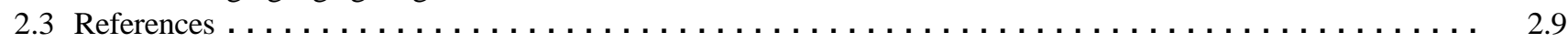

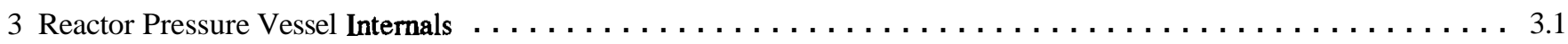

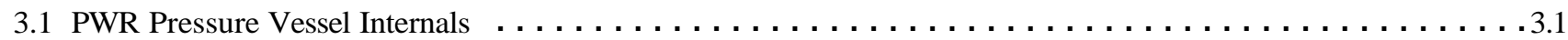



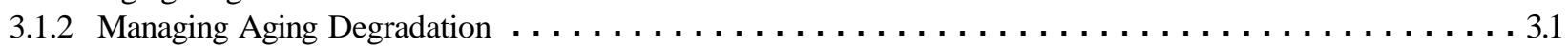

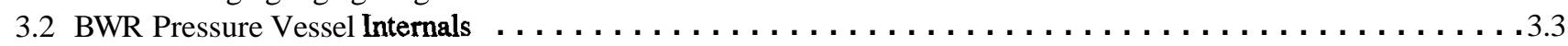

3.2.1 Aging Degradation Concerns and Mechanisms $\ldots \ldots \ldots \ldots \ldots \ldots \ldots \ldots \ldots \ldots \ldots \ldots \ldots \ldots$

3.2 .2 Managing Aging Degradation $\ldots \ldots \ldots \ldots \ldots \ldots \ldots \ldots \ldots \ldots \ldots \ldots \ldots \ldots \ldots \ldots$

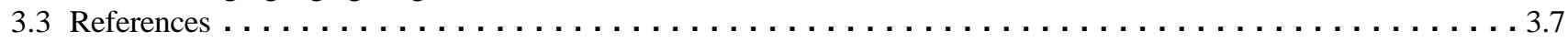

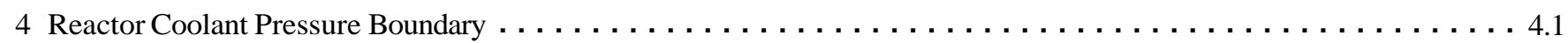

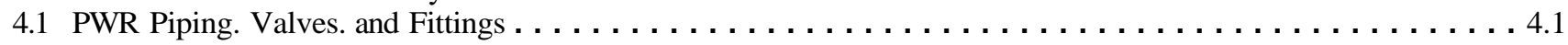

4.1 .1 Aging Degradation Concerns and Mechanisms $\ldots \ldots \ldots \ldots \ldots \ldots \ldots \ldots \ldots \ldots \ldots \ldots \ldots \ldots$

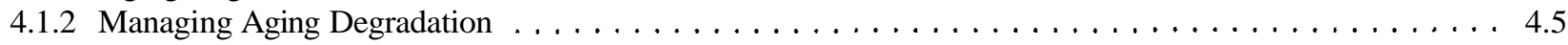

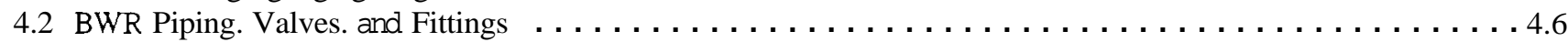

4.2 .1 Aging Degradation Concerns and Mechanisms $\ldots \ldots \ldots \ldots \ldots \ldots \ldots \ldots \ldots \ldots \ldots \ldots \ldots$

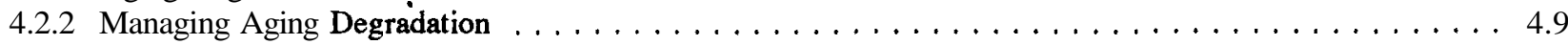

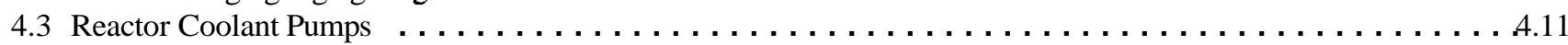



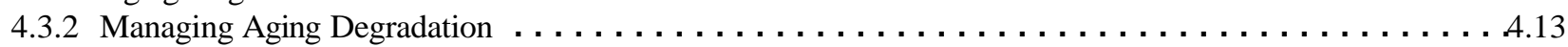

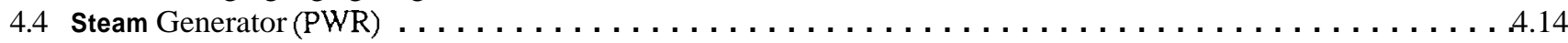

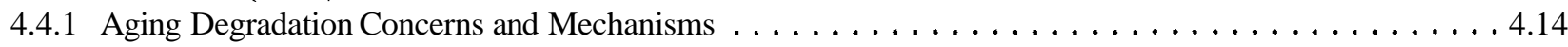

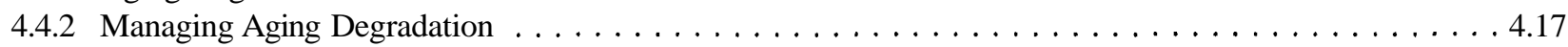




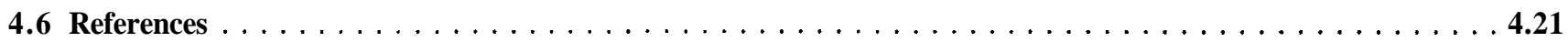

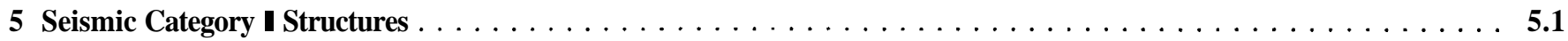

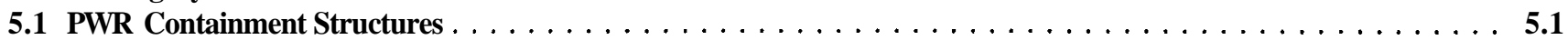

5.1 Aging Degradation Concerns and Mechanisms $\ldots \ldots \ldots \ldots \ldots \ldots$

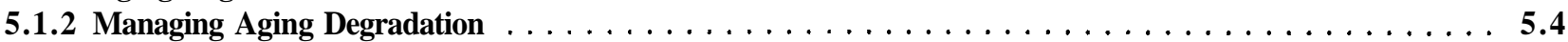

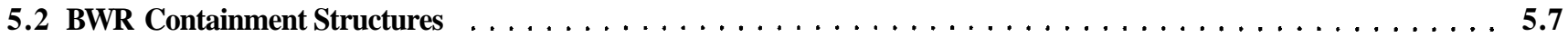

5.2.1 Aging Degradation Concerns and Mechanisms $\ldots \ldots \ldots \ldots \ldots \ldots$

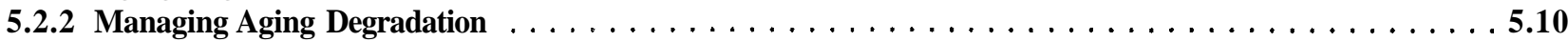

5.3 Other Seismic Category I Structures $\ldots \ldots \ldots \ldots \ldots \ldots$



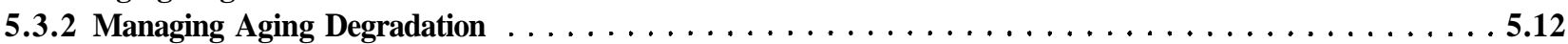

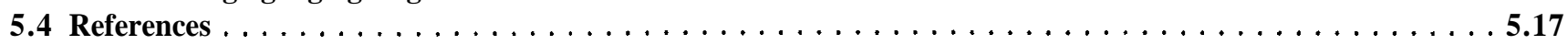

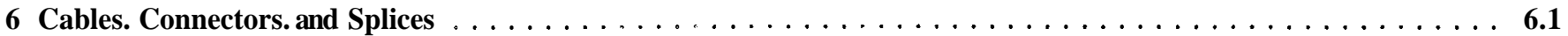

6.1 Aging Degradation Concerns and Mechanisms $\ldots \ldots \ldots \ldots \ldots$

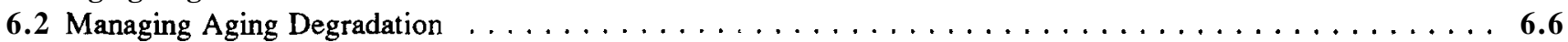

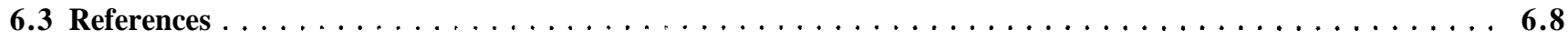




\section{Figures}

2.1 Typical PWR pressure vessel $($ Server et al. 1987) . . . . . . . . . . . . . . . . . . . . . . . . . 2.2

2.2 Typical BWR pressure vessel (Mikesell and Server 1987) . . . . . . . . . . . . . . . . . . . . . . . . 2.6

3.1 Arrangement of Westinghouse PWR internals (Ware 1989) $\ldots \ldots \ldots \ldots \ldots$

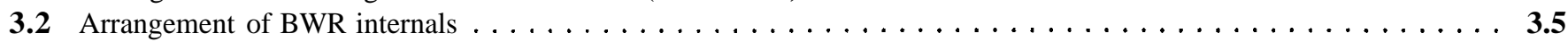

4.1 Typical two-loop combustion engineering reactor coolant system (Cloud and Server 1987) . . . . . . . . . . 4.2

4.2 Diagram of a PWR high pressure injection system (Blahnik et al. 1992) $\ldots \ldots \ldots \ldots$. . . . . . . . . . . . . . 4.4

4.3 Simplified schematic of BWR main steam system (Ware et al. 1989) $\ldots \ldots \ldots \ldots$. . . . . . . . . . . . . 4.7

4.4 Flow path during operation of RHR system in shutdown cooling mode (Lofaro et al. 1989) . . . . . . . . . . . . 4.7

4.5 Flow path during operation of RHR system in coolant injection mode (Lofaro et al. 1989) . . . . . . . . . . 4.8

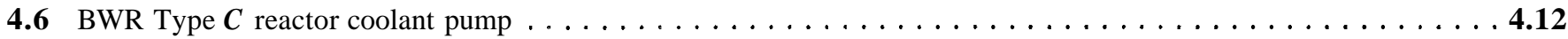

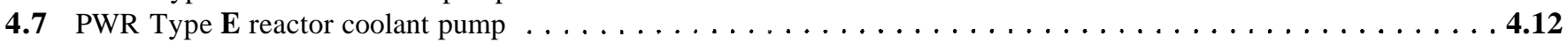

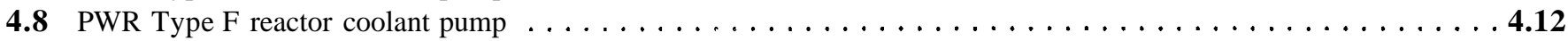

4.9 Schematic of recirculating steam generator with problem areas indicated $\ldots \ldots \ldots \ldots$

4.10 Schematic of oncethrough steam generator with problem areas indicated $\ldots \ldots \ldots \ldots$

4.11 Simplified schematic of a pressurizer system $\ldots \ldots \ldots \ldots \ldots \ldots \ldots$



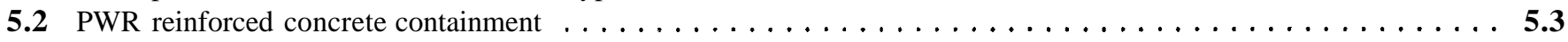

5.3 PWR cylindrical steel containment enclosed in a reinforced concrete reactor building $\ldots \ldots \ldots$

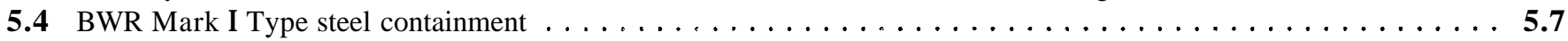

5.5 BWR Mark II Type reinforced concrete containment $\ldots \ldots \ldots \ldots \ldots \ldots$

5.6 BWR Mark III Type metal containment enclosed in a concrete shield building $\ldots \ldots \ldots \ldots$

6.1 Examples of cable construction for cables used in nuclear power plants (Gardner and Meyer 1989) . . . . . . 6.2

6.2 Raychem NPK and NPKV splice assemblies (Gardner and Meyer 1989) . . . . . . . . . . . . . . . . 6.3

6.3 Amphenol 418 Series multiconductor connector (Gardner and Meyer 1989) . . . . . . . . . . . . . . . . . . 6.3 


\section{Tables}

2.1 Aging degradation concerns and mechanisms for PWR pressure vessels $\ldots \ldots \ldots \ldots \ldots \ldots \ldots \ldots \ldots \ldots \ldots$

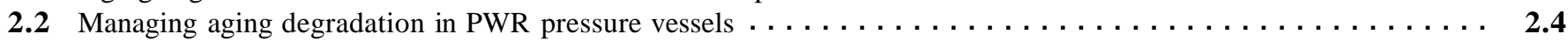

$\mathbf{2 . 3}$ Aging degradation concerns for BWR pressure vessels $\ldots \ldots \ldots \ldots \ldots \ldots \ldots \ldots \ldots \ldots \ldots \ldots \ldots \ldots \quad 2.7$

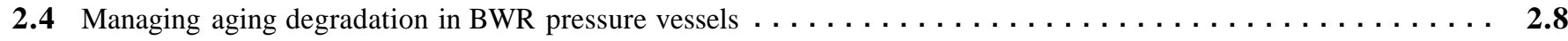

3.1 Aging degradation concerns and mechanisms for PWR vessel internals $\ldots \ldots \ldots \ldots \ldots \ldots \ldots \ldots \ldots \ldots \ldots . \ldots \ldots$

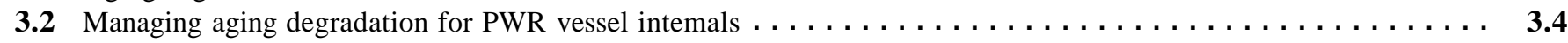

3.3 Aging degradation concerns and mechanisms for BWR vessel internals $\ldots \ldots \ldots \ldots \ldots \ldots \ldots \ldots \ldots \ldots \ldots \ldots \ldots$

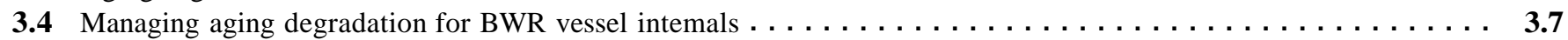

4.1 Aging degradation concerns and mechanisms for PWR CPB piping, valves. and fittings $\ldots \ldots \ldots \ldots \ldots \ldots \ldots$

4.2 Managing aging degradation of PWR CPB piping, valves, and fittings $\ldots \ldots \ldots \ldots \ldots \ldots \ldots \ldots \ldots \ldots \ldots .5$

4.3 Aging degradation concerns and mechanisms for BWR CPB piping, valves. and fittings $\ldots \ldots \ldots \ldots \ldots \ldots \ldots$

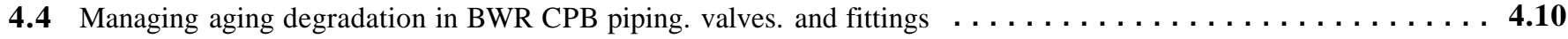

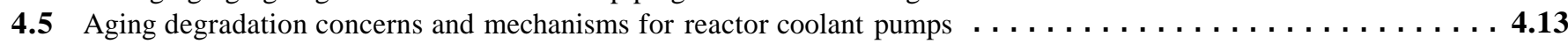

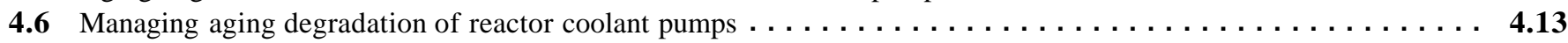

4.7 Aging degradation concerns and mechanisms for the steam generator tubes $\ldots \ldots \ldots \ldots \ldots \ldots \ldots \ldots \ldots .4 .17$

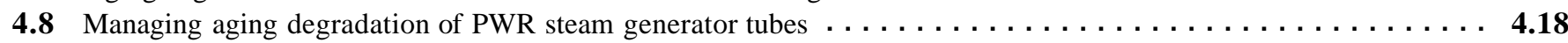

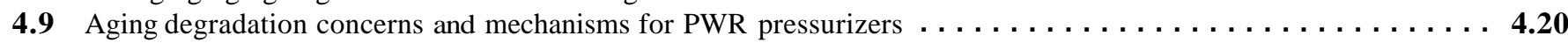

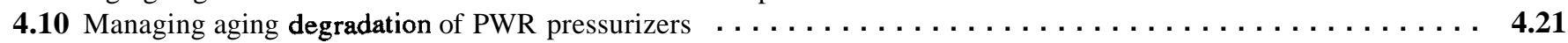

5.1 Aging degradation concerns and mechanisms for PWR containment structures $\ldots \ldots \ldots \ldots \ldots \ldots \ldots \ldots \ldots .5$

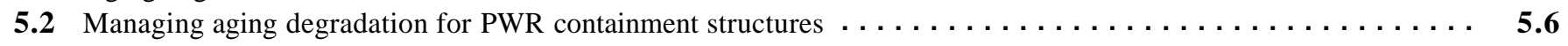

5.3 Aging degradation concerns and mechanisms for BWR containment structures $\ldots \ldots \ldots \ldots \ldots \ldots \ldots \ldots \ldots .11$

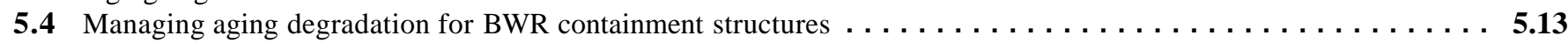

5.5 Aging degradation concerns and mechanisms for other Seismic Category I structures $\ldots \ldots \ldots \ldots \ldots \ldots \ldots .15$

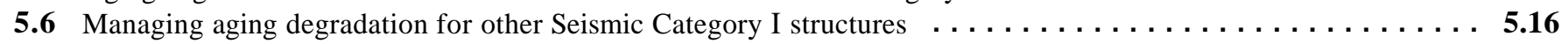

6.1 Aging degradation concerns and mechanisms for LWR cable materials $\ldots \ldots \ldots \ldots \ldots \ldots \ldots \ldots \ldots \ldots . \ldots .6 \ldots$

6.2 Aging degradation concerns and mechanisms for LWR cable splices $\ldots \ldots \ldots \ldots \ldots \ldots \ldots \ldots \ldots \ldots \ldots .6 \ldots$

6.3 Aging degradation concerns and mechanisms of LWR cable connectors $\ldots \ldots \ldots \ldots \ldots \ldots \ldots \ldots \ldots \ldots .6 \ldots$

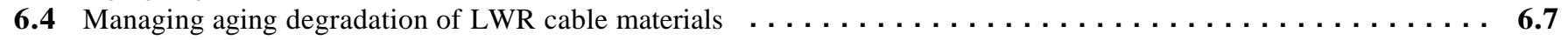



6.6 Managing aging degradation of LWR cable connectors $\ldots \ldots \ldots \ldots \ldots \ldots \ldots \ldots \ldots \ldots \ldots \ldots \ldots \ldots$ 


\section{Abbreviations/Acronyms}

\begin{tabular}{|c|c|}
\hline ASME & American Society of Mechanical Engineers \\
\hline $\begin{array}{l}\text { B\&W } \\
\text { BWR }\end{array}$ & $\begin{array}{l}\text { Babcock and Wilcox } \\
\text { boiling-water reactor }\end{array}$ \\
\hline CASS & cast austenitic stainless steel \\
\hline $\mathrm{CE}$ & Combustion Engineering \\
\hline $\mathrm{CPB}$ & coolant pressure boundary \\
\hline CRD & control rod drive \\
\hline CVCS & Chemical Volume Control System \\
\hline DBTT & ductile-to-brittle transition temperature \\
\hline ECCS & emergency core cooling system \\
\hline EPRI & Electric Power Research Institute \\
\hline HAZs & heat-affected zones \\
\hline $\mathrm{HPCl}$ & high-pressure coolant injection \\
\hline HPCS & high-pressure core spray \\
\hline HPSI & high-pressure safety injection \\
\hline IASCC & irradiation-assisted stress corrosion cracking \\
\hline ICEA & Insulated Cable Engineers Association \\
\hline IEEE & Institute of Electrical and Electronics Engineers \\
\hline IGA & intergranular attack \\
\hline IGSCC & intergranular stress corrosion cracking \\
\hline ISI & inservice inspection \\
\hline LER & licensee event report \\
\hline LOCA & loss-of-coolant accident \\
\hline LPCS & low-pressure core spray \\
\hline LWR & light-water reactor \\
\hline MOVs & motor-operated valves \\
\hline MS & main steam \\
\hline MSIV & main steam isolation valves \\
\hline NASA & National Aeronautics and Space Administration \\
\hline NEMA & National Electrical Manufacturers Association \\
\hline NPAR & Nuclear Plant Aging Research \\
\hline NPPs & nuclear power plants \\
\hline $\mathrm{NRC}$ & U.S. Nuclear Regulatory Commission \\
\hline NSSS & nuclear steam supply system \\
\hline OTSG & once-through steam generators \\
\hline PNL & Pacific Northwest Laboratory \\
\hline PT & pressure-temperature \\
\hline PTS & pressurized thermal shock \\
\hline
\end{tabular}




$\begin{array}{ll}\text { PWR } & \begin{array}{l}\text { pressurized-water reactor } \\ \text { PWSCC }\end{array} \\ \text { primary water stress corrosion cracking } \\ \text { RCIC } & \begin{array}{l}\text { reactor core isolation cooling } \\ \text { RCPB }\end{array} \\ \text { RCPs } & \begin{array}{l}\text { reactor coolant pressure boundary } \\ \text { RHR/LPCI }\end{array} \\ \text { residual heat removal/low-pressure coolant injection } \\ \text { RPV } & \begin{array}{l}\text { residual heat removal/low-pressure safety injection } \\ \text { reactor pressure vessel }\end{array} \\ \text { RSG } & \begin{array}{l}\text { recirculating steam generators } \\ \text { RT }\end{array} \\ \text { nDT } & \text { nilductility-reference temperature } \\ \text { SS } & \text { stainless steel } \\ \text { SSCs } & \text { structures, systems, and components } \\ \text { TGSCC } & \text { transgranular stress corrosion cracking } \\ \text { USE } & \text { upper-shelf energy }\end{array}$




\section{Introduction}

For several years the Nuclear Plant Aging Research (NPAR) Program ${ }^{i}$ has been developing technical understanding of the processes that, through time-dependent age-related degradation of systems, structures, and components (SSCs), could reduce operational safety margins in operating nuclear power plants (NPPs) below acceptable limits. Complementary aging management programs are conducted by the U.S. Nuclear Regulatory Commission (NRC), Office of Regulatory Research (RES); these programs focus on the development of improved nondestructive examination techniques and on understanding and managing age-related degradation of NPP pressure vessels, piping steam generators, and civil structures. Parallel programs, focused on developing the understanding needed to improve the reliability and prolong the useful life of NPP SSCs, have been instituted under the guidance of the Electric Power Research Institute (EPRI). Similar programs are being conducted in other countries, and complementary programs are being conducted to improve aging management practices in other industries, such as United States commercial and Air Force aviation programs, the U.S. Navy Extended Operating Cycle Program for nuclear submarines, and the National Aeronautics and Space Administration (NASA) programs to develop improved non-destructive examination techniques.

Pacific Northwest Laboratory (PNL) ${ }^{2}$ conducted this review to consolidate the information being developed by these programs in a form that is "user friendly" for both the NRC staff and NPP licensees. Because of its summary nature, the information contained in this report is not intended to be sufficiently detailed to satisfy all applications. Extensive references have been provided to guide the reader to more comprehensive specific sources when needed.

\subsection{Organization}

Part 1 of this report reviews information on understanding and managing aging of long-lived, passive, nonredundant systems and components. Understanding and managing aging for other SSCs that have been subjects of NPAR investigations are reviewed in Part 2.

Each section of the report addresses a particular SSC and describes the aging concerns and mechanisms as well as approaches to managing the degradation. Further subdivisions are made where significant differences exist between boiling water reactors (BWRs) and pressurized water reactors (PWRs) SSC aging issues. References are provided at the end of each section.

\subsection{Terminology}

Terminology used in this report follows consensus definitions developed by a technical committee composed of members from the utility industry and regulatory research (Grant and Miller 1992).

\subsection{Aging and Research Programs}

The status and accomplishments (through calendar year [CY] 1990) of the NPAR Program are reviewed by Vora (1991); Bosnak (1992) gives an updated overview of the program.

All reports generated in the NPAR Program (through September 1993) are summarized and indexed by Vora (1993); this report has been updated annually for 4 years.

'Conducted under the auspices of the Division of Engineering, Office of Nuclear Regulatory Research (RES) , U.S. Nuclear Regulatory Commission (NRC).

${ }^{2}$ PNL is operated by Battelle Memorial Institute for the U.S. Department of Energy. 
Scott et al. (1992) summarize pertinent insights regarding aging management practices of the United States commercial airline industry, the U.S. Air Force B-52 bomber program, the U.S. Navy ballistic submarine fleet, and the Japanese nuclear power industry.

\subsection{General Guidance}

Christensen (1992), Dukelow (1992), and Vora and Burns (1989) are good sources for general information regarding the need for, and the processes necessary to establish, effective aging management programs.

Blahnik et al. (1992), Fresco et al. (1993), Gunther and Taylor (1990) and Shah and MacDonald (1993) are good sources for summary reviews of insights gained from specific NPAR activities.

\subsection{References}

Blahnik, D.E., D.A. Casada, J.L. Edson, D.L. Fineman, and W.E. Gunther. 1992. Insight Gained From Aging Research. NUREGICR-5643, U.S. Nuclear Regulatory Commission, Washington, D.C.

Bosnak, R. 1992. "NRC Plant Aging Research Program-Overview." In Proceedings of the Aging Information Conference. NUREGICP-0122, Vol. 1, pp. 15-28, U.S. Nuclear Regulatory Commission, Washington, D.C.

Christensen, J.A. 1992. "Managing Aging in Nuclear Power Plants," Nucl. Eng. Design, 134:245.

Dukelow, J.S. 1992. Recordkeeping Needs to Mitigate the Impact of Aging Degradation. NUREG/CR-5848, U.S. Nuclear Regulatory Commission, Washington, D.C.

Fresco, A., M. Subudhi, W. Gunther, E. Grove, and J. Taylor. 1993. Managing Aging in Nuclear Power Plants: Insights From NRC Maintenance Team Inspection Reports. NUREG/CR-5812, U.S. Nuclear Regulatory Commission, Washington, D.C.

Grant, W.S., and E.J. Miller. 1992. Nuclear Power Plant Common Aging Terminology. EPRI TR-100844, Electric Power Research Institute, Palo Alto, California.

Gunther, W., and J. Taylor. 1990. Results from the Nuclear Plant Aging Research Program: Their Use in Inspection Activities. NUREGICR-5507, U.S. Nuclear Regulatory Commission, Washington, D.C.

Scott, W.B., W.I. Enderlin, A.D. Chockie, and K.A. Bjorklo. 1992. "Good Practices for Effective Maintenance to Manage Aging of Nuclear Power Plants," Nucl. Eng. Design, 134:257.

Shah, V. N. and P. E. MacDonald, eds. 1993. Aging and Life Extension of Major Light Water Reactor Components. Elsevier Science Publishers, Amsterdam, The Netherlands.

Vora, J.P. 1991. Nuclear Plant Aging Research (NPAR) Program Plan. NUREG-1144, Rev. 2, U.S. Nuclear Regulatory Commission, Washington, D.C.

Vora, J.P. 1993. NRC Research Program on Plant Aging: Listing and Summaries of Reports Issued Through September 1993. NUREG-1377, Rev. 4, U.S. Nuclear Regulatory Commission, Washington, D.C.

Vora, J.P. and J.J. Burns. 1989. "Understanding and Managing Aging and Maintenance." In Proceedings of the International Nuclear Power Plan Aging Symposium, ed. F.A. Beranck, NUREGICP-01000, pp. 28-38, U.S. Nuclear Regulatory Commission, Washington, D.C. 


\section{Reactor Pressure Vessels}

The reactor pressure vessel (RPV) is part of the reactor pressure coolant boundary, as defined in 10 CFR 50.2. As such, the RPV cames the NRC Quality Group A designation and, except where specifically exempted by the provisions of 10 CFR 50.55a, must meet the requirements for the American Society of Mechanical Engineers (ASME) Class 1 components as set forth in Section III of the ASME Boiler and Pressure Vessel Code.

The primary functions of the RPV are to contain the reactor coolant and to provide a bamer to fission product release. In addition, the RPV supports the vessel internals, control rods. and core and directs the reactor coolant flow that facilitates the transfer of heat generated in the core to the steam turbine (boiling-water reactor [BWR]) or steam generator [pressurized-water reactor [PWR]).

This chapter reviews aging degradation of RPV components in PWRs and BWRs. Aging of other systems and components that comprise the reactor coolant pressure boundary is reviewed in Chapter 4, and aging of the RPV internals is reviewed in Chapter 3.

\subsection{PWR Pressure Vessels}

This section addresses the aging degradation of the low alloy femtic steel and stainless steel components that comprise the PWR pressure vessel. This includes the closure head dome (which cames the control rod drive mechanism housings, vent tubes, lifting lugs, refueling seal ledge, and shroud support ring), the closure head flange, closure stud assemblies (composed of studs, nuts, washers, and O-rings), the vessel flange, the upper shell course (including primary coolant nozzles, safety injection nozzles, and leakage monitoring tubes), intermediate and lower shell courses (including the core support lugs), and the bottom head dome (including the instrument tube penetrations). The function of each of these components is largely self-explanatory. These components are shown in Figure 2.1.

Pressure vessels of PWRs constructed after 1963 comply with the ASME Boiler and Pressure Vessel Code, Section III, which permitted about $25 \%$ lower wall thickness than the previous Sections I and VII, but required a more extensive nondestructive examination of the welds. Although earlier RPVs were fabricated from welded plate sections, later vessels, used ring forgings for the shell courses, thus eliminating the longitudinal welds. The upper shell course is about $30 \%$ thicker than the others to account for the nozzle penetrations. Nozzles are also forgings. Although welddeposited stainless steel is used for the vessel internal cladding (to mitigate corrosion), Alloy 600 is used in local regions where Alloy 600 components are attached. The cladding is generally not included in estimates of vessel-wall strengths. Postweld heat treatments are used to reduce residual stresses.

\subsubsection{Aging Degradation Concerns and Mechanisms}

Aging degradation concerns and mechanisms for PWR pressure vessels are summarized in Table 2.1. In order of priority, the most important concerns are radiation embrittlement and fatigue cracking. The most important sites for concern on the RPV are the weldments in the beltline region, weldments at the housings for the control rod drive (CRD) mechanisms and in-core instrument penetrations, and the flange closure studs.

Embrittlement is more of a concern for PWRs than BWRs because of the thinner water annulus surrounding the core in the PWR, which results in neutron fluences 20 to 100 times higher. Radiation embrittlement of the beltline region (composed of the intermediate and lower shell courses) is most important for the beltline weldments, because low-copper, damage resistant pressure-vessel steel (SA533B-1) has become standard for the shell courses (the base metal). The welds are more easily 


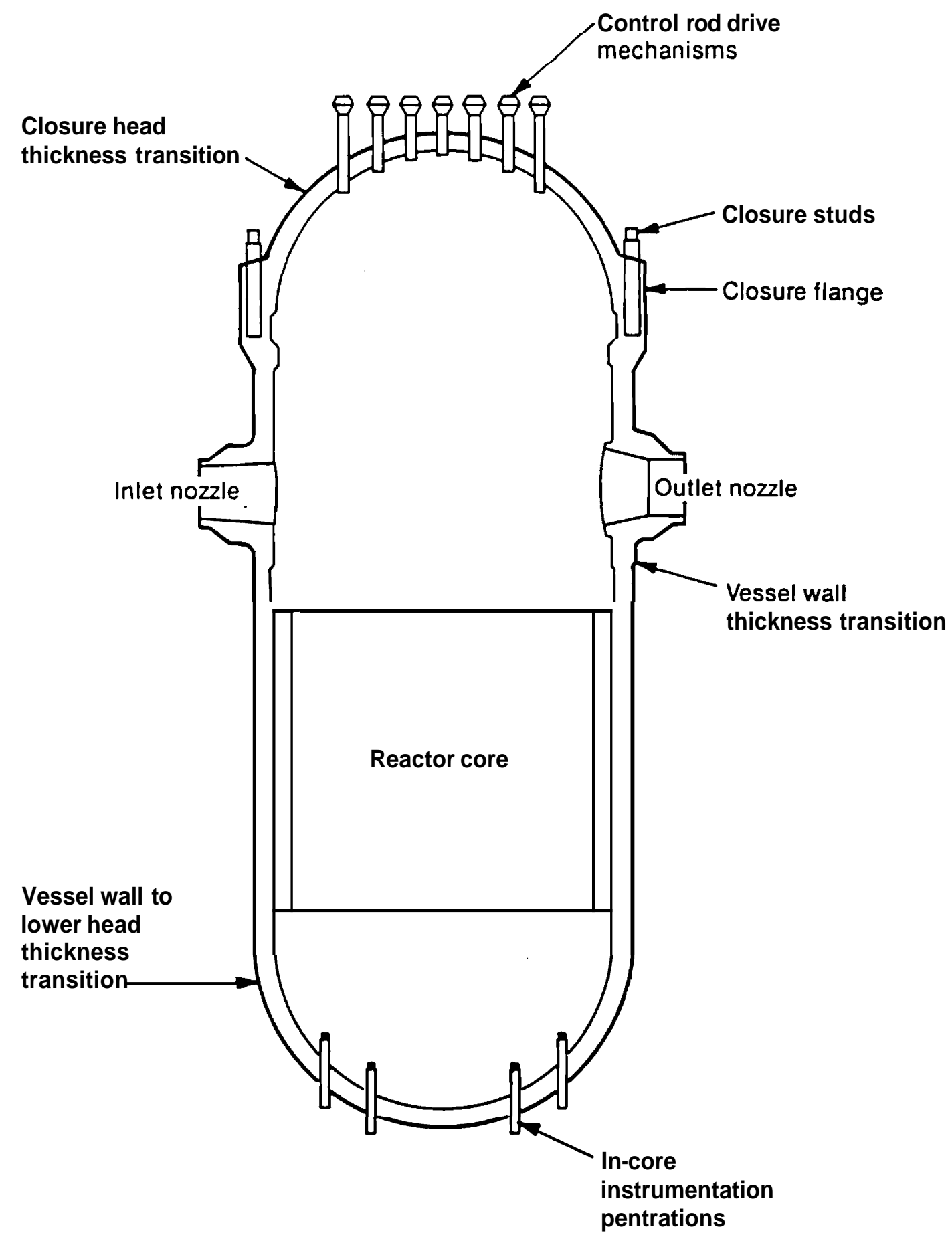

Figure 2.1 Typical PWR pressure vessel (Sewer et al. 1987) 
Table 2.1 Aging degradation concerns and mechanisms for PWR pressure vessels

\begin{tabular}{||l|l|l|l|l||}
\hline \hline PWR RPV Component & \multicolumn{1}{|c|}{ Materials } & Aging Concerns & Aging Mechanisms & \multicolumn{1}{c||}{ References* } \\
\hline $\begin{array}{l}\text { Beltine region, shell, } \\
\text { nozzles, cladding }\end{array}$ & $\begin{array}{l}\text { SA508; SA533B-1; } \\
\text { SA336; SA508; Stainless } \\
\text { steel; Alloy 600 }\end{array}$ & $\begin{array}{l}\text { Loss of fracture } \\
\text { toughness; Crack } \\
\text { initiation and growth }\end{array}$ & $\begin{array}{l}\text { Radiation } \\
\text { embrittlement; } \\
\text { Environmental fatigue }\end{array}$ & $\begin{array}{l}\text { pp. 29-31 } \\
\text { p. 32 } \\
\text { Reg. Guide 1.99 Rev. 2 } \\
10 \text { CFR 50.61 (PTS) } \\
\text { p. 57 }\end{array}$ \\
\hline $\begin{array}{l}\text { Coolant outlet and inlet } \\
\text { nozzles }\end{array}$ & SA508 & $\begin{array}{l}\text { Crack initiation and } \\
\text { growth }\end{array}$ & Fatigue & p. 53 \\
\hline $\begin{array}{l}\text { Instrument penetrations } \\
\text { and CRD housings }\end{array}$ & SB166: SB167 & $\begin{array}{l}\text { Crack initiation and } \\
\text { growth }\end{array}$ & $\begin{array}{l}\text { Fatigue; IGSCC; Boric } \\
\text { acid corrosion }\end{array}$ & $\begin{array}{l}\text { p. 53 } \\
\text { p. 32 }\end{array}$ \\
\hline $\begin{array}{l}\text { Flange closure studs } \\
\text { Crack initiation and } \\
\text { growth; Loss of material }\end{array}$ & $\begin{array}{l}\text { Fatigue; Boric acid } \\
\text { corrosion }\end{array}$ & $\begin{array}{l}\text { Generic Letter 88-05 (NRC } \\
1988 \mathrm{a}) ; \text { pp. 32 \& 53 }\end{array}$ \\
\hline \multicolumn{1}{|l|}{ SA540-B23 and B24 } \\
\hline \hline
\end{tabular}

embrittled than the base metal because of copper, nickel. and phosphorous impurities, because of the dissimilar metals joined together, and because of the presence of the heat-affected zones (HAZs) of the weld.

Embrittlement raises the reference temperature for nil ductility transition $\left(\mathrm{RT}_{\mathrm{NDT}}\right.$ ) and lowers the upper-shelf energy (USE) for Charpy impact tests. The result is that the allowable pressure-temperature (PT) operating range of the plant may be restricted. The USE of about twenty U.S. PWRs may fall to below $50 \mathrm{ft}-\mathrm{lb}$ by the end of their initial license periods. Such reductions often result in a lowering of the low temperature overpressure protection setpoint. The most serious unanticipated transient that can exceed the PT limits is pressurized thermal shock (PTS), the low-temperature overpressurization, and rapid cooldown of the downcomer coolant while at relatively high primary system pressure.

Degradation by fatigue cracking can occur for the beltline weldments (due to normal operating pressure/thermal cycling and abnormal events), closure head studs (load cycling due to normal operation and maintenance), primary coolant inlet and outlet nozzles (due to thermal cycling), and instrument penetrations and CRD housings (due to thermal cycling). The thermal cycling can be caused by normal operating thermal transients, such as heatup or cooldown associated with servicing and by a number of unanticipated or design transients (see Shah and MacDonald 1993, p. 31).

Although crack initiation generally occurs at or near strain concentrations, such as nozzle welds, PWRs generally do not accumulate enough cycles to initiate cracks. Initiation is predicted by the classical S-N approach (stress vs. the number of cycles for failure). Crack growth rates are predicted using the linear elastic fracture mechanism approach, which depends on initial crack length. The initial crack length is one of the most uncertain parameters in the equations, unless it has been carefully measured (e.g., by ultrasonic methods). Predicting the growth of small cracks is also difficult because it often requires an extensive material database and an elastic-plastic analysis. Difficulty increases when the effects of the environment are incorporated into the analysis. Sulfur (from the manganese sulfide inclusions in the base metal or weld) can si cantly accelerate crack growth rates in oxygenated water environments. Fatigue damage can be more limiting than embrittlement for RPVs fabricated from low-copper steels.

Other issues of aging, such as corrosion-assisted fatigue cracking in the vessel cladding, are of lesser importance, although CRD housings made from Alloy 600 are susceptible to intergranular stress corrosion cracking (IGSCC). General corrosion and stress corrosion cracking are usually not a problem in PWR vessel cladding because benign conditions for stainless steel are maintained by adherence to proven water chemistry guidelines (Wood 1990). On external surfaces, boric acid corrosion can degrade the flange and closure studs if not managed properly.

gnifi 


\subsubsection{Managing Aging Degradation}

There are three broad categories of management options available for managing radiation embrittlement of the beltline region: mitigation, inspection and surveillance, and repair. There are three approaches to mitigate embrittlement: the reduction of thermal stresses, flux reductions, and thermal annealing.

The options for managing aging degradation of PWR pressure vessels are shown in Table 2.2. Reductions in thermal stresses during operation can be approached by training operators to avoid or eliminate certain off-normal sequences. A more expensive option is to change the plant design to minimize stress concentrations, such as increasing the temperature of the emergency core cooling system (ECCS) water. The neutron flux can be reduced by improved fuel management, such as the "low-leakage loading pattern," or by shielding the beltline welds. The latter must be implemented early in the RPV life to be effective, and consists of replacing some fuel pellets with stainless steel balls in the weld region. The thermal annealing option for mitigation of embrittlement can be accomplished either wet or dry, the latter offering the most complete recovery of vessel ductility. Guidance for this procedure is found in ASTM E 509. Because there are no established methods for predicting reembrittlement after annealing, post-anneal measurements are essential. Samples from the vessel wall will also be required to check the through-thickness annealing response.

There are two methods of vessel inservice inspection: ultrasonic examination and acoustic emission. Ultrasonic examinations are usually performed to characterize flaws in weldments and HAZs, per Section XI of the ASME code. The significant uncertainties in this method, especially for underclad flaws, have resulted in conservative regulatory requirements for use of these flaw estimates to set PT limits and evaluate PTS events. Section XI of the ASME code requires four inspections at 10-year intervals, during which $100 \%$ volumetric inspections are required for all shell, head, shell-to-flange, nozzle-to-vessel, and repair welds in the beltline region. This provides a close monitoring of possible fatigue crack initiation and growth. Smooth, sharpedged flaws normal to the vessel surface and in the embrittled beltline region are the most important for PTS, but are also difficult to detect and characterize. Some advanced ultrasonic methods have been developed for this purpose (Shah and MacDonald 1993, p. 65). Acoustic emission monitoring can be used for on-line monitoring of crack growth if the outside surface of the vessel is accessible.

Table 2.2 Managing aging degradation in PWR pressure vessels

\begin{tabular}{|c|c|c|c|c|}
\hline $\begin{array}{l}\text { PWR RPV } \\
\text { Component }\end{array}$ & Materials & $\begin{array}{c}\text { Aging } \\
\text { Mechanisms } \\
\end{array}$ & Management Options & References' \\
\hline $\begin{array}{l}\text { Beltline region, } \\
\text { shell, nozzles, } \\
\text { cladding }\end{array}$ & $\begin{array}{l}\text { SA508; SA533B-1; } \\
\text { SA336; SA508; } \\
\text { Stainless steel; Alloy } \\
600\end{array}$ & $\begin{array}{l}\text { Radiation } \\
\text { embrittlement; } \\
\text { Environmental } \\
\text { fatigue }\end{array}$ & $\begin{array}{l}\text { Stress cycle reductions; Thermal } \\
\text { annealing; Flux .reductions; vessel } \\
\text { anneal; Ultrasonic inspection of } \\
\text { welds; Acoustic emission; } \\
\text { Surveillance programs; Weld repair }\end{array}$ & $\begin{array}{l}\text { pp. } 59-60 \\
\text { p. } 61 \\
\text { p. } 60 \\
\text { p. } 62 \text {; ASTM E } 509 \\
\text { p. } 64 \text {; Regulatory Guide } 1.150 \text { Rev. } \\
1 \text { (NRC } 1983 \text { ) } \\
\text { p. } 68 \\
\text { p. } 70 \text {; ASTM E } 185 \\
\text { p. } 76\end{array}$ \\
\hline $\begin{array}{l}\text { Coolant outlet } \\
\text { and inlet } \\
\text { nozzles }\end{array}$ & SA508 & Fatigue & $\begin{array}{l}\text { Stress cycle reductions; Plant PT } \\
\text { history records }\end{array}$ & p.59 \\
\hline $\begin{array}{l}\text { Instrument } \\
\text { penetrations and } \\
\text { CRD housings } \\
\end{array}$ & SB166; SB167 & $\begin{array}{l}\text { Fatigue; } \\
\text { IGSCC; Boric } \\
\text { acid corrosion } \\
\end{array}$ & $\begin{array}{l}\text { Stress cycle reductions; Coolant } \\
\text { chemistry control; Materials } \\
\text { changes; Inspections }\end{array}$ & $\begin{array}{l}\text { p. } 59 \\
\text { pp. } 645-652\end{array}$ \\
\hline $\begin{array}{l}\text { Flange closure } \\
\text { studs }\end{array}$ & SA540-B23 and B24 & $\begin{array}{l}\text { Fatigue; Boric } \\
\text { acid corrosion }\end{array}$ & $\begin{array}{l}\text { Volumetric and surface inspections; } \\
\text { Replacement }\end{array}$ & $\begin{array}{l}\text { Generic Letter 88-05 (NRC1988a); } \\
\text { pp. } 32 \text { and } 53\end{array}$ \\
\hline
\end{tabular}


Managing embrittlement by surveillance programs is a regulatory requirement. The typical surveillance program consists of placing at least three samples of the base metal, the weld metal, and the HAZ metal in small irradiation capsules. The capsules are then placed between the RPV inner wall and the core thermal shield at the beitline level. Because the flux is higher than at the vessel wall itself, the fluence of the surveillance samples leads that of the vessel by factors of 1 to 5 . The sample material is usually archive material. When this is not available, reconstituted samples or surrogate materials (ASTM E 1253) can be used if properly justified. The specimen withdrawal schedule is dictated by ASTM E 185. Results from Charpy impact testing to find the $\mathrm{RT}_{\mathrm{NDT}}$ and USE of these specimens provide estimates of radiation embrittlement that are then compared with predictive methodologies such as Regulatory Guide 1.99 Rev. 2 (NRC 1988b) and ASTM E 900. Correlation monitor materials also placed in the surveillance capsules serve to verify fluences and temperatures. ASTM E 636 provides additional information on supplemental testing of the surveillance samples. However, note that ASTM E 900 and Regulatory Guide 1.99 (NRC 1988b) do not provide guidance for temperatures outside the nominal range of 274 to $310^{\circ} \mathrm{C}\left(525^{\prime \prime}\right.$ to $\left.590^{\circ} \mathrm{F}\right)$.

The last option for the aging management of beltline welds is by repair. The shielded metal arc weld using the temper bead technique is acceptable in the ASME code and does not require a postweld heat treatment. However, this is a labor-intensive procedure and may be subject to strain aging. The gas tungsten-arc weld method is suited to remote operations inside the vessel, requires no heat treatment, and is less susceptible to strain aging.

Options for managing the fatigue degradation of coolant nozzles, instrument penetration, and CRD housings by minimizing thermal cycle occurrences and severity (by training and redesign, respectively) were discussed in the first paragraph of this section. Modeling of the fatigue damage to corroborate measurements requires that the plant PT history be carefully recorded for the analysis of crack growth by the damage tolerant fracture mechanics approach. Management of the fatigue and corrosion of the flange closure studs is by volumetric and surface inspections, along with replacement of defective studs.

\subsection{BWR Pressure Vessels}

This section addresses the aging degradation of the low alloy ferritic steel and stainless steel components that comprise the BWR pressure vessel. This includes the vessel beltline and other courses, beltline weldments, vessel flange, vessel top and bottom heads, closure studs, support skirt, attachment welds for the vessel internals, nozzles, penetrations, and safe ends. These components are shown in Figure 2.2. Components belonging to the reactor vessel internal systems are not included. Control rod drive mechanisms are also not included.

All BWR pressure vessels in the United States were constructed from formed and welded plates. Vessels constructed after about 1970 used a low-alloy femtic steel with low copper content to reduce susceptibility to radiation embrittlement. The vessel inner surface is clad with welddeposited stainless steel to inhibit general corrosion. In older vessels, the cladding was either not applied or was removed in specific local areas so that vessel internals could be welded to the low-alloy steel. In newer vessels, the cladding has been classified as a structural material, and the internals are welded to the cladding. The entire vessel is subjected to a stress relief heat treatment after all welds are completed.

The vessel top head, flange, and closure studs permit sealing of the RPV after refueling operations, etc. The many nozzles on the BWR pressure vessel handle coolant flow to and from the core, along with control rod drives on some designs. The safe ends are essentially short sections of piping welded to the nozzle, and provide a stable location for welding the coolant piping to the nozzle. Penetrations occur in the lower head and permit insertion of control rod drives and core flux monitors.

\subsubsection{Aging Degradation Concerns and Mechanisms}

Aging degradation concerns and mechanisms for BWR pressure vessel are summarized in Table 2.3. In order of priority, the primary mechanisms of concern are IGSCC, thermal and mechanical fatigue, and radiation embrittlement.

Intergranular stress corrosion cracking can occur at vessel nozzle and attachment welds due to the combination of high residual and applied stresses, a high coolant electrochemical potential, and the use of Alloy 182 weld materials. Specific BWR nozzle-to-safe end welds that have been susceptible to IGSCC are the recirculation system inlet, core spray, and feedwater. Attachment welds for the control rod drive stub tubes have also been susceptible. A vessel with a very low femte content in 


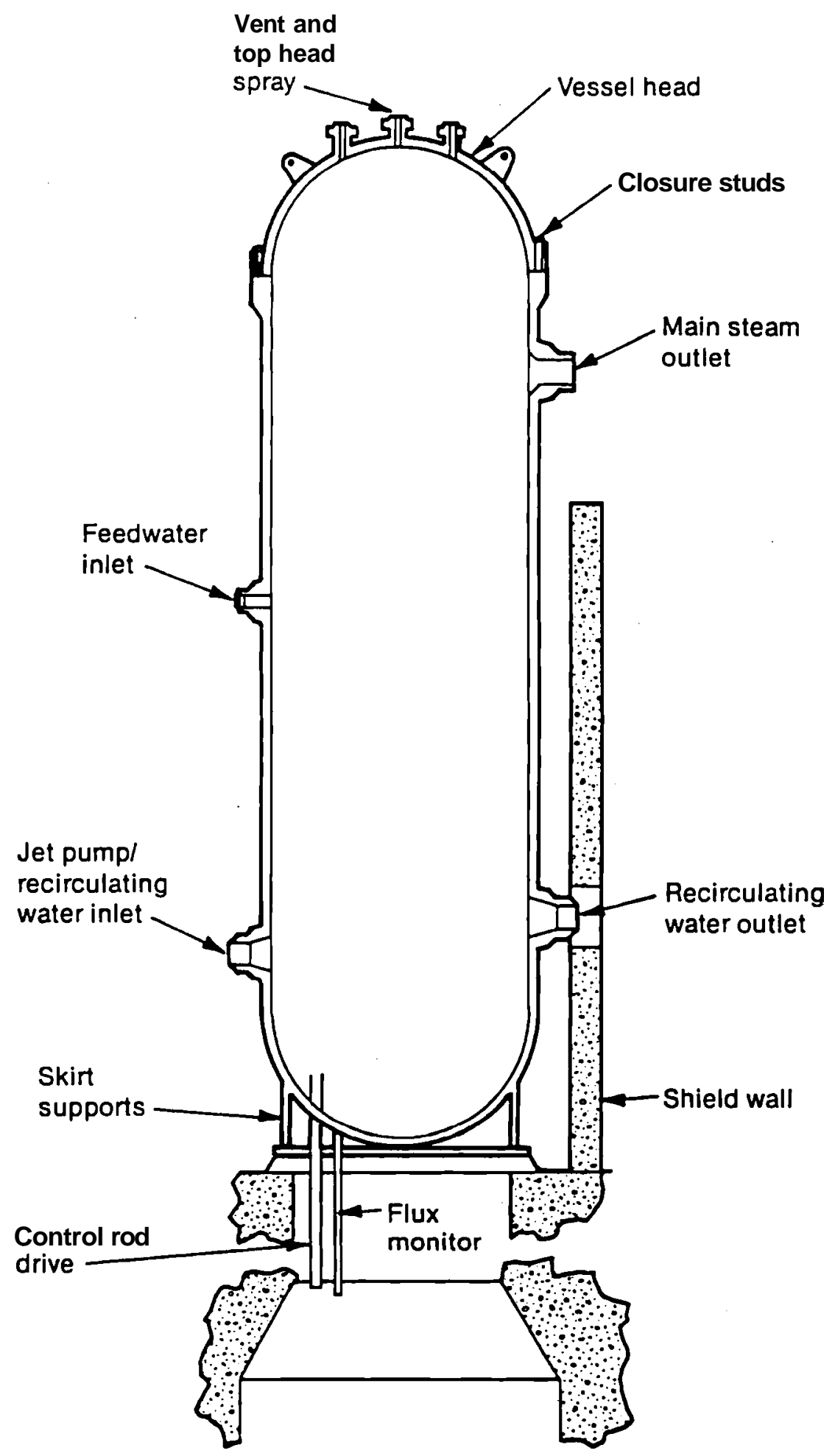

Figure 2.2 Typical BWR pressure vessel (Mikesell and Sewer 1987) 
Table 2.3 Aging degradation concerns for BWR pressure vessels

\begin{tabular}{|c|c|c|c|c|}
\hline BWR RPV Components & Materials & Aging Concerns & Aging Mechanisms & References' \\
\hline $\begin{array}{l}\text { Nozzle welds (incl. instr. and } \\
\text { CRD); Attachment welds }\end{array}$ & $\begin{array}{l}\text { SA508 Class 2; Alloy } \\
182 \text { (welds) }\end{array}$ & $\begin{array}{l}\text { Crack initiation and } \\
\text { growth }\end{array}$ & $\begin{array}{l}\text { Intergranular stress } \\
\text { corrosion cracking }\end{array}$ & p. 645 \\
\hline $\begin{array}{l}\text { Nozzles (feedwater and CRD } \\
\text { return) }\end{array}$ & $\begin{array}{l}\text { SA508 Class } 2 \\
\text { Stainless steel cladding }\end{array}$ & $\begin{array}{l}\text { Crack initiation; Low- } \\
\text { cycle crack growth }\end{array}$ & $\begin{array}{l}\text { High-cycle thermal } \\
\text { fatigue }\end{array}$ & p. 642 \\
\hline $\begin{array}{l}\text { Closure stud assemblies; } \\
\text { Flanges }\end{array}$ & $\begin{array}{l}\text { SA193, SA540: SA508 } \\
\text { Class } 2\end{array}$ & $\begin{array}{l}\text { Leakage; Crack } \\
\text { initiation and growth }\end{array}$ & $\begin{array}{l}\text { Wear; Fatigue; Stress } \\
\text { corrosion cracking }\end{array}$ & p. 645 \\
\hline Beltline shell and weld & $\begin{array}{l}\text { SA533B-1; Proprietary } \\
\text { welds }\end{array}$ & $\begin{array}{l}\text { Loss of fracture } \\
\text { toughness }\end{array}$ & $\begin{array}{l}\text { Radiation } \\
\text { embrittlement }\end{array}$ & p. 647 ; Reg. Guide 1.99 \\
\hline External attachments & SA533B-1 & $\begin{array}{l}\text { Crack initiation and } \\
\text { growth; Ductile } \\
\text { overload }\end{array}$ & $\begin{array}{l}\text { Thermal and } \\
\text { mechanical fatigue }\end{array}$ & p. 645 \\
\hline Vessel cladding & $\begin{array}{l}\text { Low femte stainless } \\
\text { steel }\end{array}$ & $\begin{array}{l}\text { Crack initiation and } \\
\text { growth }\end{array}$ & Interdendritic SCC & p. 641 \\
\hline
\end{tabular}

the cladding can be sensitive to interdendritic IGSCC. Repairs for these components have included some nozzle redesign, replacement of the weld material with corrosion resistant Alloy 82, and control of the hydrogen water chemistry.

However, increasing the coolant hydrogen can also have adverse effects, such as increased steamline radiation fields, increased radioactivity deposition on some surfaces, increased erosion-corrosion of carbon steel components, and increased hydrogen absorption by fuel cladding. Closure studs occasionally exhibit SCC due to unexpected material deficiencies, wear of protective coatings, and moist environments.

Boiling-water reactor vessels were designed for fatigue using the classic S-N curve (stress vs. number of cycles for failure) approach and test data from polished samples in air atmospheres at room temperature. Safety factors of 2 for stress and 20 for cycles were applied. Although the fatigue strength of low-alloy steels does not fall below the ASME design curves, the safety margins are substantially reduced by exposure to high temperature oxygenated water (such as BWR coolant) during low-cycle fatigue tests. The above safety factors only partially account for the environmental effects. However, environment has little effect on high-cycle fatigue because the high strain rates do not allow sufficient time for chemical reactions to occur at typical kinetic rates. Corrosion fatigue is accelerated by the oxygen and sulfur in the BWR environment, although there appears to be a stress threshold below which such acceleration is not observed.

Nozzles on feedwater and CRD hydraulic return lines have experienced cracking from thermal fatigue. Turbulent mixing of the cooler feedwater and hotter coolant near the feedwater nozzle can cause thermal fluctuations, of up to $42^{\circ} \mathrm{C}\left(108^{\circ} \mathrm{F}\right)$ and up to $1 \mathrm{~Hz}$, and have resulted in initiation of high-cycle fatigue cracks up to $6 \mathrm{~mm}(0.24 \mathrm{in}$.) deep.

Low-cycle corrosion fatigue during heatup, cooldown, etc., have propagated the cracks through the cladding and into the base metal, to a total depth of $38 \mathrm{~mm}(1.5 \mathrm{in}$.). The cracks have been repaired by grinding or remachining the nozzles. Stratified flows and turbulent mixing have also caused circumferential cracking in the vessel walls up to $200 \mathrm{~mm}$ (7.9 in.) away from the CRD return line nozzles, which were repaired similarly. The main closure stud assemblies and flanges are also subjected to low-cycle fatigue.

Radiation embrittlement causes loss of fracture toughness in the RPV beltline region, where the fluence is highest. Older vessels were fabricated from materials that contained small amounts of copper, nickel, and phosphorus, which increase radiation embrittlement. Newer vessels (after 1970) were fabricated from materials with reduced $\mathrm{Cu}, \mathrm{Ni}$, and $\mathrm{P}$ impurities (Reg. Guide 1.99, Rev. 2). Radiation embrittlement causes changes in two key regulatory parameters: increases in the reference 
ductile-to-brittle transition temperature $\left(\mathrm{RT}_{\mathrm{NDT}}\right)$ and decreases in the USE for fracture by the Charpy V-notch test. Weldments are usually more susceptible to these changes than the base metal. Radiation embrittlement by fast neutrons ( $>1 \mathrm{MeV})$ is less important for BWRs than for PWRs because of the greater amount of moderating coolant water between the reactor core and the vessel shell. However, embrittlement may impose constraints on BWR cold hydrotest procedures, and may limit the range of acceptable operating transients in older plants. Irradiation-assisted stress corrosion cracking (IASCC), corrosion, erosion/corrosion, fretting and wear, and stress relaxation appear to be negligible problems for BWR pressure vessels.

\subsubsection{Managing Aging Degradation}

The options for managing aging degradation in BWR pressure vessels are outlined in Table 2.4. The aging effects of IGSCC on nozzle and attachment welds can be managed by five approaches: materials-related remedies, temporary repairs, control of hydrogen water chemistry, ultrasonic examinations, and visual inspections. Materials-related remedies include replacement of the Alloy 182 welds with the corrosion-resistant Alloy 82, or a more temporary repair by weld overlaying Alloy 82 on top of the original Alloy 182 weld. Other related nozzle repairs have included replacement of the safe end with a new material and a nozzle design change to eliminate a crevice which promoted corrosive chemistries. IGSCC of nozzle and attachment welds can also be effectively suppressed by control of hydrogen water chemistry in the primary coolant. However, the high hydrogen injection rates have several disadvantages (Shah and MacDonald 1993, p. 647). Ultrasonic examination and visual inspections of nozzle and attachment welds in the beltline region of BWR pressure vessels are severely hampered by lack of accessibility, even for designs completed after the ASME Section XI Code was implemented (1971). Many of the beltline nozzle welds have not been inspected since construction, and the blanket exemption previously granted by the NRC may not be available in the future. Remotely operated inspection systems are being developed.

The aging effects of thermal and mechanical fatigue on feedwater and CRD return line nozzles may be managed by periodic ultrasonic inspection. This has been done from the external surface using a phased array ultrasonic method. However, these nozzles may also be inspected for fatigue cracks on internal surfaces with the traditional liquid penetrant method, which is more difficult because of accessibility problems. On-line monitoring of temperatures and coolant flow and pressure, coupled with leakage monitoring, has also been used in place of liquid penetrant testing. An SCC monitor may also be employed to estimate IGSCC crack growth (Shah and MacDonald 1993, Chapters 19 and 22).

Table 2.4 Managing aging degradation in BWR pressure vessels

\begin{tabular}{|c|c|c|c|c|}
\hline $\begin{array}{c}\text { BWR RPV } \\
\text { Components } \\
\end{array}$ & Materials & Aging mechanisms & Management options & References' \\
\hline $\begin{array}{l}\text { Nozzle welds (incl. } \\
\text { Instr. and CRD); } \\
\text { Attachment welds }\end{array}$ & $\begin{array}{l}\text { SA508 Class 2; Alloy } \\
182 \text { (welds) }\end{array}$ & $\begin{array}{l}\text { Intergranular stress } \\
\text { corrosion cracking }\end{array}$ & $\begin{array}{l}\text { Materials-related remedies; } \\
\text { Temporary repair; Hydrogen } \\
\text { water chemistry; Ultrasonic } \\
\text { examination; Visual inspection }\end{array}$ & $\begin{array}{l}\text { p. } 645 \\
\text { p. } 655 \\
\text { p. } 647 \\
\text { p. } 651 \\
\text { p. } 652 \\
\end{array}$ \\
\hline $\begin{array}{l}\text { Nozzles (feedwater and } \\
\text { CRD return line) }\end{array}$ & $\begin{array}{l}\text { SA508 Class } 2 \text {; } \\
\text { Stainless steel cladding }\end{array}$ & $\begin{array}{l}\text { High-cycle thermal } \\
\text { fatigue }\end{array}$ & $\begin{array}{l}\text { Ultrasonic inspection or liquid } \\
\text { penetrant on-line monitoring }\end{array}$ & $\begin{array}{l}\text { p. } 642 \\
\text { p. } 652 \\
\text { p. } 654 \\
\end{array}$ \\
\hline $\begin{array}{l}\text { Closure stud } \\
\text { assemblies; Flanges }\end{array}$ & $\begin{array}{l}\text { SA193, SA540; SA508 } \\
\text { Class } 2\end{array}$ & $\begin{array}{l}\text { Wear; Fatigue; Stress } \\
\text { corrosion cracking }\end{array}$ & $\begin{array}{l}\text { Surface and volumetric } \\
\text { inspections; Replacement }\end{array}$ & $\begin{array}{l}\text { p. } 653 \\
\text { p. } 649\end{array}$ \\
\hline Beltline shell and weld & $\begin{array}{l}\text { SA533B-1; Proprietary } \\
\text { welds }\end{array}$ & Radiation embrittlement & $\begin{array}{l}\text { Volumetric inspection; } \\
\text { Surveillance samples }\end{array}$ & $\begin{array}{l}\text { p. } 651 \\
\text { Mattu et al. } 1989 \\
\text { p. } 653\end{array}$ \\
\hline External attachments & SA533 B-1 & $\begin{array}{l}\text { Thermal and mechanical } \\
\text { fatigue }\end{array}$ & $\begin{array}{l}\text { Volumetric and surface } \\
\text { inspections }\end{array}$ & p. 652 \\
\hline Vessel cladding & $\begin{array}{l}\text { Low ferrite stainless } \\
\text { steel }\end{array}$ & Interdendritic SCC & Visual examination & p. 652 \\
\hline
\end{tabular}


The aging effects of fatigue, wear, and SCC on closure stud assemblies and flanges can be managed by in situ ultrasonic test- * ing during outages (an angle beam technique seems preferable), and by replacement if cracked studs are identified. Wear and fretting of studs and flanges can be identified by visual inspection of the surface condition.

Radiation embrittlement of the beltline shell and welds can be managed by remotely controlled ultrasonic inspection. When accessibility permits, both inside and outside remote inspection equipment have been developed. Still, not all welds can be reached in older vessels. Thus, at least three surveillance capsules containing specimens most susceptible to radiation embrittlement (e.g., HAZ of weldments) are placed adjacent to the vessel inner wall. These specimens are withdrawn according to a schedule and tested for fracture toughness (see Shah and MacDonald 1993, Chapter 3).

Aging degradation due to fatigue of vessel external attachments, such as the support skirt, can be managed by periodic ultrasonic and visual inspection, which can be performed remotely in most cases with advanced equipment. Similar equipment can be used to check the vessel interior cladding for stress corrosion cracks. This can be performed while the internal attachment welds are being inspected.

\subsection{References}

10 CFR 50.2. U.S.Code of Federal Regulations. 1992. "Definitions." U.S. Nuclear Regulatory Commission, Washington, D.C.

10 CFR 50.55a. U.S. Code of Federal Regulations. 1992. "Codes and Standards." U.S. Nuclear Regulatory Commission, Washington, D.C.

10 CFR 50.61. U.S. Code of Federal Regulations. 1992. "Fracture toughness requirements for protection against pressurized thermal shock events." U.S. Nuclear Regulatory Commission, Washington, D.C.

American Society of Mechanical Engineers (ASME) Boiler and Pressure Vessel Code, Section XI. 1992. Rules for InService Inspection (ISI) of Nuclear Power Plant Components. American Society of Mechanical Engineers, New York.

American Society for Testing and Materials (ASTM) E 185. 1994. Standard Practice for Conducting Surveillance Tests for Light Water Cooled Nuclear Power Reactor Vessels, Annual Book of ASTM Standards, Volume 12.02. American Society for Testing and Materials, Philadelphia.

American Society for Testing and Materials (ASTM) E 509. 1991. Standard Guide for In-Service Annealing of Light Water Cooled Nuclear Power Reactor Vessels, Annual Book of ASTM Standards, Volume 12.02. American Society for Testing and Materials, Philadelphia.

American Society for Testing and Materials (ASTM) E 636. 1983. Standard Guide for Supplemental Surveillance Tests for Nuclear Power Reactor Vessels, Annual Book of ASTM Standards, Volume 12.02. American Society for Testing and Materials, Philadelphia.

American Society for Testing and Materials (ASTM) E 900. 1994. Standard Guide for Predicting Neutron Radiation Damage or Reactor Vessel Materials, Annual Book of ASTM Standards, Volume 12.02. American Society for Testing and Materials, Philadelphia.

American Society for Testing and Materials (ASTM) E 1253. 1993. Standard Guide for Reconstitution of Irradiated Charpy Specimens, Annual Book of ASTM Standards. American Society for Testing and Materials, Philadelphia.

Mattu, R.K., W.F. Anderson, L. Connor, and V.M. Kapila. 1989. BWR Reactor Vessel In-Service Inspection Data Base, EPRI NP-6601. Electric Power Research Institute, Palo Alto, California.

Mikesell, W.R., and W.L. Server. 1987. "Boiling Water Reactor Pressure Vessels." In Residual Life Assessment of Major Light Water Reactor Components--Overview Volume I, eds. V.N. Shah and P.E. MacDonald. NUREG/CR-4731 
(EGG-2469), Volume 1, pp. 101-107, prepared by Robert L. Cloud Associates under contract to EG\&G Idaho, Inc., for the U.S. Nuclear Regulatory Commission, Washington, D.C.

Server, W.L., G.R. Odette, and R.O. Ritchie. 1987. "Pressurized Water Reactor Pressure Vessels. " In Residual Life Assessment of Major Lighr Water Reactor Components - Overview Volume 1, eds. V.N. Shah and P.E. MacDonald.

NUREG/CR-4731 (EGG-2469) Volume 1, pp. 12-31. prepared by Robert L. Cloud Associates and University of California under contract to EG\&G Idaho. Inc., for the U.S. Nuclear Regulatory Commission, Washington, D.C.

Shah, V.N., and P.E. MacDonald, eds. 1993. Aging and Life Extension of Major Lighr Water Reactor Components. Elsevier Publishing, New York.

U.S. Nuclear Regulatory Commission (NRC). 1983. Ultrasonic Testing of Reactor Vessel Welds During Preservice and Inservice Examinations. Regulatory Guide 1.150, Rev. 1, U.S. Nuclear Regulatory Commission, Washington, D.C.

U.S. Nuclear Regulatory Commission (NRC). 1988a. Boric Acid Corrosion of Carbon Steel Reactor Pressure Boundary Components in PWR Plants. NRC Generic Letter 88-05, Supplement 1, U.S. Nuclear Regulatory Commission, Washington, D.C.

U.S. Nuclear Regulatory Commission (NRC). 1988b. Radiation Embrittlement of Reactor Vessel Materials. Regulatory Guide 1.99, Rev. 2, U.S. Nuclear Reguiatory Commission, Washington, D.C.

Wood, C.J. 1990. PWR Primary Water Chemistry Guidelines: Revision 2. EPRI NP-7077, Electric Power Research Institute, Palo Alto, California. 


\section{Reactor Pressure Vessel Internals}

This chapter reviews aging degradation of RPV internals in PWRs and BWRs; aging degradation of the RPVs is addressed in Chapter 2. The internal components of light-water reactor (LWR) pressure vessels provide orientation and support for the reactor core and guide and protect the control rod drive assemblies. They also provide a passageway, support, and protection for in-vessel instrumentation and direct water flows as necessary.

\subsection{PWR Pressure Vessel Internals}

This section addresses the aging degradation of ferritic steels, wrought austenitic stainless steel (SS), cast austenitic stainless steel (CASS), and nickel base alloy components that comprise the PWR reactor vessel internals. The review covers the Upper Internals Assembly components (such as the upper support plate, upper core plate, upper support columns, and in-core instrumentation guide tubes), the Core Support Assembly components (such as the core support shield, core barrel, shroud assembly, thermal shield, and upper core plate alignment pins), and the Lower Internals Assembly components (such as the lower core plate, lower support plate, lower support columns, radial keys, clevis inserts, secondary support structure, and in-core instrumentation guide tubes). The PWR internals support the reactor core, the control rod assembly, the core support structure, and the irradiation surveillance specimens; direct the flow of reactor coolant; and provide shielding for the reactor pressure vessel. Specific components vary among the three domestic PWR reactors designed by Babcock and Wilcox (B\&W), Combustion Engineering (CE), and Westinghouse; Figure 3.1 shows the layout for a typical PWR plant.

\subsubsection{Aging Degradation Concerns and Mechanisms}

Internals of PWRs are manufactured from wrought and cast stainless steels, ferritic steels, and high-temperature nickel alloys. These materials have been susceptible to cracking, leakage, and failure from fatigue, IGSCC, and irradiation and thermal embrittlement under the complex stresses from thermal plant transients, flow-induced vibration, high-temperature corrosive environment, radiation, and bolting preloads. Aging degradation concerns considered to be significant for PWR internals are 1) crack initiation and growth due to crevice cracking and IASCC from stresses concentrated at weld regions and at geometrical discontinuities, thermal and mechanical cycling of these weldments, the coolant water, and neutron irradiation; 2) attrition of pins, ribs, and flanges caused by mechanical wear; 3) loss of fracture toughness of core support and lower internal assembly components due to neutron irradiation and thermal embrittlement; 4) loss of preload of bolts due to stress relaxation; and 5) cumulative fatigue damage to components due to high- and low-cycle fatigue. These significant aging degradation concerns and their mechanisms are summarized in Table 3.1.

\subsubsection{Managing Aging Degradation}

A summary of options for managing significant aging degradation in PWR internals through inservice inspections, surveillance, monitoring, repair, and replacement is provided in Table 3.2. A primary requirement for aging management is to ensure against loss of core restraint and guidance and protection of control rod drive assemblies due to irradiation-assisted stress corrosion cracking and embrittlement.

Reactor internals are difficult to inspect. Visual inspection of accessible areas of reactor internals can provide information on physical damage, leakage, and mechanical and structural condition. Inservice inspection of all flange-closure stud-bolting each time the head is removed enables removal of degraded components. Components removed to a pool or remaining in the vessel can be inspected by remote camera. Ultrasonic inspection is difficult to apply and to interpret. Eddy-current inspection is effective in measurement of tube or pipe thinning. Loose-parts monitoring systems are complex (Weiss and Mayo 1991). More effective remote inspection tools are needed.

As for the pressure vessel, higher operating temperatures should retard the rate of radiation embrittlement in the reactor internals and water chemistry management should prevent the initiation of stress corrosion cracks in attachment welds. 


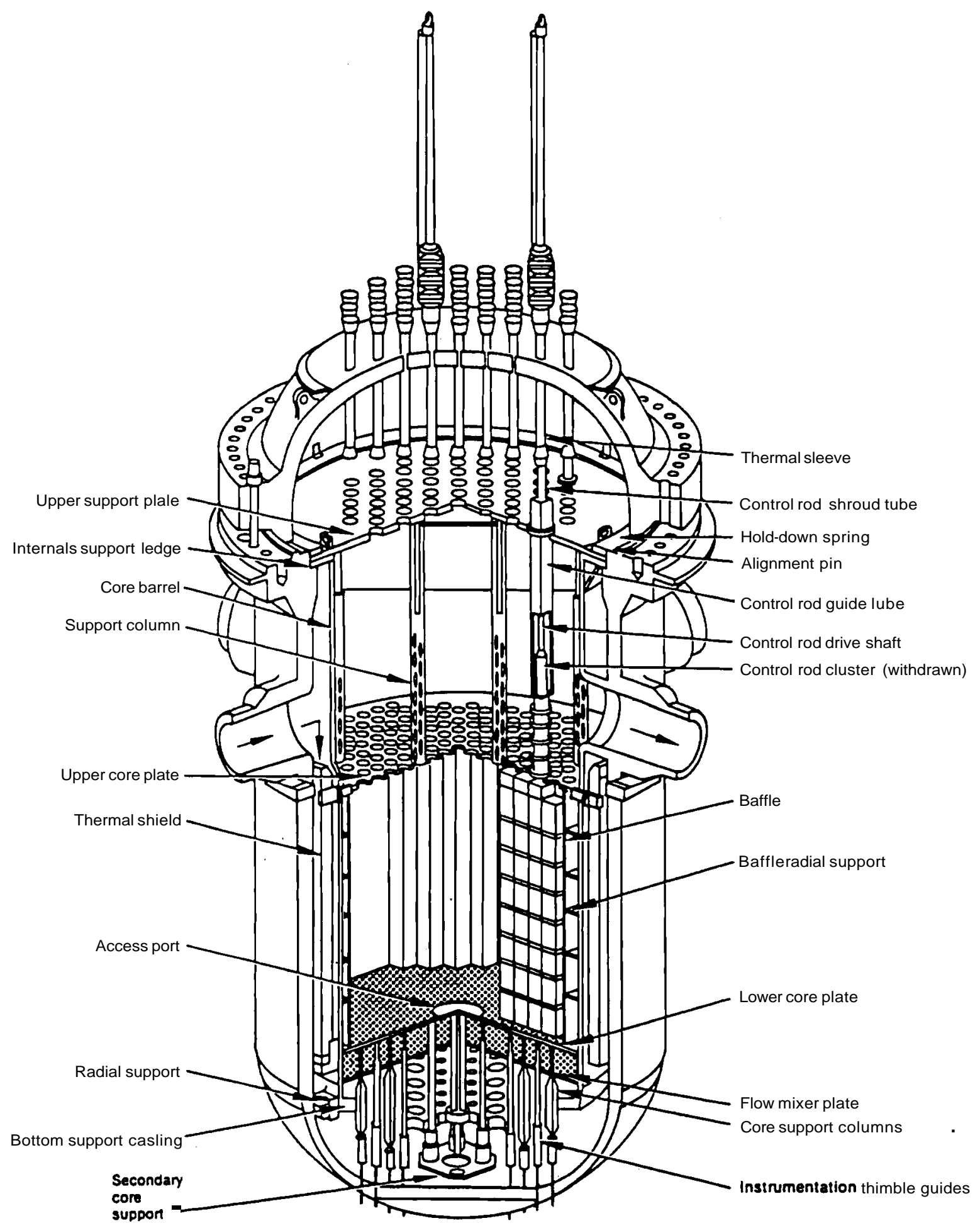

Figure 3.1 Arrangement of Westinghouse PWR internals (Ware 1989) 
Table 3.1 Aging degradation concerns and mechanisms for PWR vessel internals

\begin{tabular}{|c|c|c|c|c|}
\hline Components & Materials & Aging Concerns & Aging Mechanisms & References' \\
\hline \multirow[t]{2}{*}{ All components } & \multirow[t]{2}{*}{$\begin{array}{l}\text { SS; Nicrobraze; Ni } \\
\text { alloys; CASS; Stellite }\end{array}$} & $\begin{array}{l}\text { Crack initiation } \\
\text { and growth }\end{array}$ & $\begin{array}{l}\text { Irradiation-assisted } \\
\text { stress corrosion } \\
\text { cracking }\end{array}$ & $\begin{array}{l}\text { Andresen et al. } \\
\text { 1990; Luk 1993a }\end{array}$ \\
\hline & & $\begin{array}{l}\text { Loss of fracture } \\
\text { toughness }\end{array}$ & Radiation embrittlement & pp. $466-467$ \\
\hline $\begin{array}{l}\text { Guide tubes; fuel alignment plate; } \\
\text { upper core barrel flange, upper core } \\
\text { plate alignment pins; fuel alignment } \\
\text { pins; radial keys and clevis inserts }\end{array}$ & $\begin{array}{l}\mathrm{SS}, \text { Nicrobraze: Ni } \\
\text { alloys }\end{array}$ & Loss of function & Wear & pp.463-464 \\
\hline \multirow{2}{*}{$\begin{array}{l}\text { Guide tube bolts: upper support col- } \\
\text { umn bolts; baffle and former assembly } \\
\text { bolts; fuel alignment pins; lower sup- } \\
\text { port column bolts }\end{array}$} & \multirow[t]{2}{*}{$\mathrm{SS} ; \mathrm{Ni}$ alloys } & $\begin{array}{l}\text { Crack initiation } \\
\text { and growth }\end{array}$ & $\begin{array}{l}\text { Stress corrosion } \\
\text { cracking }\end{array}$ & $\begin{array}{l}\text { pp. } 458-462 \\
\text { pp. } 465-466\end{array}$ \\
\hline & & Loss of preload & Stress relaxation & Causey et al. 1980 \\
\hline $\begin{array}{l}\text { Upper support columns; lower } \\
\text { support plate; lower support columns }\end{array}$ & CASS & $\begin{array}{l}\text { Loss of fracture } \\
\text { toughness }\end{array}$ & Thermal embrittlement & Chopra 1992 \\
\hline $\begin{array}{l}\text { Upper support plate; guide tube; } \\
\text { guide tube bolts; upper support } \\
\text { column bolts; core barrel nozzles; } \\
\text { upper core plate alignment pins; lower } \\
\text { core plate; lower support columns }\end{array}$ & $\begin{array}{l}\mathrm{SS} ; \text { Nicrobraze; } \mathrm{Ni} \\
\text { alloys }\end{array}$ & $\begin{array}{l}\text { Cumulative } \\
\text { fatigue damage }\end{array}$ & Fatigue & $\begin{array}{l}\text { Berge and de } \\
\text { Keroulas } 1989 \\
\text { Olivera and } \\
\text { Pierrey } 1989\end{array}$ \\
\hline
\end{tabular}

Accurate records of operating cycles and transients for reactor vessel and internals provide key information required to evaluate fatigue usage factors and can be used to enhance the effectiveness of inspections. Vibration monitoring and trending can assist preventive maintenance planning.

\subsection{BWR Pressure Vessel Internals}

This section addresses the aging degradation of wrought austenitic SS, CASS, and nickel base alloy components that comprise the BWR vessel internals. The review covers the major BWR internals, which are (from bottom to top of the vessel) the core plate assembly, fuel supports, jet pump assemblies, core shroud, top guide, core spray lines and spargers, feedwater spargers, shroud head, and steam separator and dryer assemblies. The BWR internals provide orientation and support the reactor core; guide and protect the control rod assemblies; provide passageway, support, and protection for in-vessel instrumentation; direct the flow of reactor coolant within the pressure vessel; separate steam from water; and provide emergency core cooling water to the fuel assemblies. The layout for a typical BWR plant is illustrated in Figure 3.2.

\subsubsection{Aging Degradation Concerns and Mechanisms}

BWR internals are manufactured from wrought and cast SS, femtic steels, and high-temperature nickel alloys. These materials have been susceptible to IGSCC, cracking from fatigue, irradiation and thermal embrittlement, leakage, and failures from the high-temperature corrosive coolant, prolonged exposure to high neutron fluxes, thermal transients during plant heatups and cooldowns, high preload stresses in bolts and studs, and flow-induced vibrations (Shah and MacDonald 1993, pp. 765-776). Aging degradation concerns considered to be significant for BWR internals are crack initiation and growth due to 
Table 3.2 Managing aging degradation for PWR vessel internals

\begin{tabular}{|c|c|c|c|c|}
\hline Components & Materials & Aging Mechanisms & $\begin{array}{c}\text { Management } \\
\text { Options }\end{array}$ & References \\
\hline \multirow[t]{2}{*}{ All components } & \multirow[t]{2}{*}{$\begin{array}{l}\text { SS, } \\
\text { Nicrobraze; Ni } \\
\text { alloys; CASS; } \\
\text { Stellite }\end{array}$} & $\begin{array}{l}\text { Irradiation-assisted stress } \\
\text { corrosion cracking }\end{array}$ & \multirow[t]{6}{*}{$\begin{array}{l}\text { Visual VT-3 } \\
\text { examination; } \\
\text { replacement }\end{array}$} & \multirow[t]{6}{*}{$\begin{array}{l}\text { ASME Section XI, Subsection } \\
\text { IWB, examination category } \\
\text { B-N-3. }\end{array}$} \\
\hline & & Radiation embrittlement & & \\
\hline $\begin{array}{l}\text { Guide tubes; fuel alignment plate; } \\
\text { upper core barrel flange; upper core } \\
\text { plate alignment pins; fuel alignment } \\
\text { pins; radial keys and clevis inserts }\end{array}$ & $\begin{array}{l}\mathrm{SS} ; \\
\text { Nicrobraze; Ni } \\
\text { alloys }\end{array}$ & Wear & & \\
\hline \multirow{2}{*}{$\begin{array}{l}\text { Guide tube bolts; upper support } \\
\text { column bolts; baffle and fonner } \\
\text { plates; assembly bolts; fuel alignment } \\
\text { pins; lower support column bolts }\end{array}$} & SS; Ni alloys & Stress corrosion cracking & & \\
\hline & & Stress relaxation & & \\
\hline $\begin{array}{l}\text { Upper support columns; lower } \\
\text { support plate; lower support columns }\end{array}$ & CASS & Thermal embrittlement & & \\
\hline $\begin{array}{l}\text { Upper support plate; guide tube; } \\
\text { guide tube bolts; upper support } \\
\text { column bolts; core barrel nozzles; } \\
\text { upper core plate alignment pins; } \\
\text { lower core plate; lower support } \\
\text { columns }\end{array}$ & $\begin{array}{l}\mathrm{SS} ; \\
\text { Nicrobraze; } \mathrm{Ni} \\
\text { alloys }\end{array}$ & Fatigue & $\begin{array}{l}\text { Visual VT-3 } \\
\text { examination; } \\
\text { reanalysis of } \\
\text { usage factor; } \\
\text { transient } \\
\text { monitoring; } \\
\text { replacement }\end{array}$ & $\begin{array}{l}\text { ASME Section XI, Subsection } \\
\text { IWB, examination category } \\
\text { B-N-3; ASME Section III. } \\
\text { Subsection NG-5200 }\end{array}$ \\
\hline
\end{tabular}

IGSCC and IASCC from stresses concentrated at weld regions and at geometrical discontinuities, thermal and mechanical cycling of these weldments, the coolant water, and neutron radiation. An aging concern specific to the BWR internals is the deposition of minerals on the internal surfaces of the jet pumps. These significant aging degradation concerns and their mechanisms are summarized in Table 3.3.

\subsubsection{Managing Aging Degradaition}

A summary of options for managing sign cant aging degradation in BWR internals through inservice inspections, surveillance, monitoring, repair, and replacement is provided in Table 3.4. A primary requirement for aging management is to ensure against loss of core restraint, guidance, and protection of control rod drive assemblies, and emergency core cooling due to IGSCC and IASCC.

Reactor internals are difficult to inspect. Visual inspection of accessible areas of reactor internals can provide information on physical damage, leakage, and mechanical and structural condition. Inservice inspection of all flangeclosure stud-bolting each time the head is removed enables removal of degraded components.

Components removed to a pool or remaining in the vessel can be inspected by remote camera. Ultrasonic inspection is difficult to apply and to interpret. Eddy-current inspection is effective in measurement of tube or pipe thinning. Loose parts monitoring systems are complex (Weiss and Mayo 1991). More effective remote inspection tools are needed. 


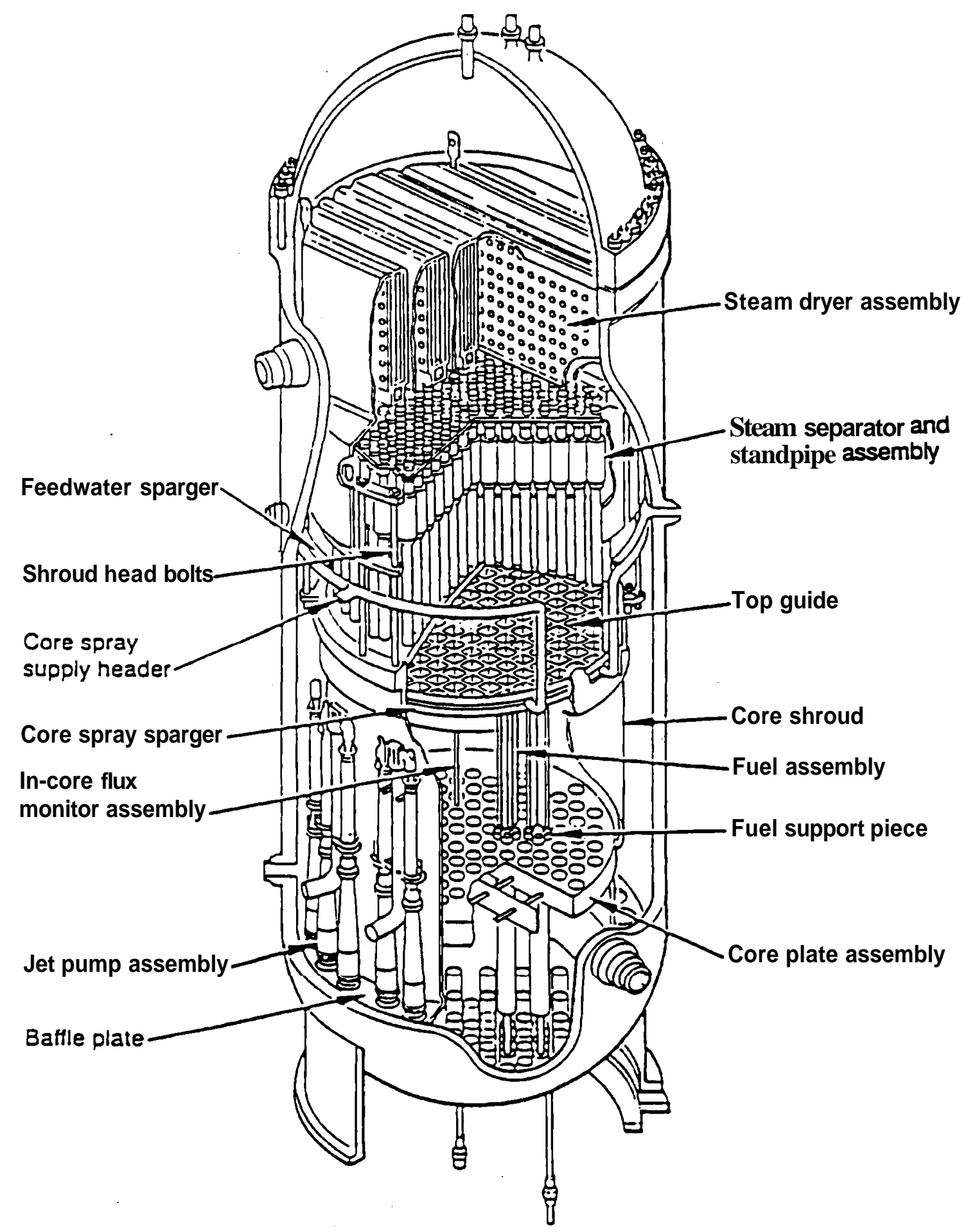

Figure 3.2 Arrangement of BWR internals 
Table 3.3 Aging degradation concerns and mechanisms for BWR vessel internals

\begin{tabular}{||l|l|l|l|l||}
\hline \hline \multicolumn{1}{|c|}{ Components } & Materials & Aging Concerns & Aging Mechanisms & References' \\
\hline Jet pump & 300 -series SS & $\begin{array}{l}\text { Loss of core } \\
\text { flow }\end{array}$ & $\begin{array}{l}\text { Deposition of mineral on } \\
\text { jet pump internals }\end{array}$ & GE SIL 465, Supplement 1 \\
\hline $\begin{array}{l}\text { Access hole cover; control blades: } \\
\text { control rod drive housing; tubes }\end{array}$ & Alloy 600; SS & $\begin{array}{l}\text { Crack initiation } \\
\text { and growth }\end{array}$ & $\begin{array}{l}\text { Intergranular stress } \\
\text { corrosion cracking }\end{array}$ & $\begin{array}{l}\text { van Rooyen 1975; Luk 1993b; } \\
\text { Andresen et al. 1988 }\end{array}$ \\
\hline $\begin{array}{l}\text { Control blades; core shroud head bolts; } \\
\text { core spray sparger; monitor tubes }\end{array}$ & SS; Alloy 600 & $\begin{array}{l}\text { Crack initiation } \\
\text { and growth }\end{array}$ & $\begin{array}{l}\text { Irradiation-assisted stress } \\
\text { corrosion cracking }\end{array}$ & Nelson and Andresen 1991 \\
\hline $\begin{array}{l}\text { Core shroud } \\
\text { Crack initiation } \\
\text { and growth }\end{array}$ & $\begin{array}{l}\text { Stress corrosion cracking } \\
\text { (SSC) }\end{array}$ & SS & $\begin{array}{l}\text { Fatigue } \\
\text { fatigue damage }\end{array}$ & Luk 1993b; p. 775 \\
\hline $\begin{array}{l}\text { Control blades; control rod drive } \\
\text { housing; core shroud head bolts; core } \\
\text { spray internal piping; core spray } \\
\text { sparger; monitor tubes; jet pump; } \\
\text { orificed fuel support; steam dryer } \\
\text { support bracket }\end{array}$ & $\begin{array}{l}\text { Alloy 600; } \\
\text { Alloy X-750 }\end{array}$ & $\begin{array}{l}\text { SS; CASS; } \\
\text { 'Unless otherwise noted, the references are to pages of Shah and MacDonald (1993). }\end{array}$ & \\
\hline \hline
\end{tabular}


Table 3.4 Managing aging degradation for BWR vessel internals

\begin{tabular}{|c|c|c|c|c|}
\hline Components & Materials & Aging Mechanisms & Management Options & References \\
\hline Jet pump & '300-series SS & $\begin{array}{l}\text { Deposition of } \\
\text { minerals on jet pump } \\
\text { internals }\end{array}$ & $\begin{array}{l}\text { Review records of core flow; Visual } \\
\text { inspections; Clean jet pump mixers }\end{array}$ & $\begin{array}{l}\text { GE SIL } 465, \text { Supplement } \\
1\end{array}$ \\
\hline Access hole cover & Alloy 600 & $\begin{array}{l}\text { Intergranular stress } \\
\text { corrosion cracking }\end{array}$ & $\begin{array}{l}\text { Plant-specific volumetric inspection; } \\
\text { repair via attachment of reinforcement } \\
\text { hardware }\end{array}$ & GE SIL 462S1 \\
\hline \multirow[t]{2}{*}{ Control blades } & \multirow[t]{2}{*}{ SS } & $\begin{array}{l}\text { Intergranular stress } \\
\text { corrosion cracking }\end{array}$ & $\begin{array}{l}\text { Plant-specific operational parameter } \\
\text { monitoring, inspection, evaluation, and } \\
\text { replacement }\end{array}$ & Accepted current practice \\
\hline & & $\begin{array}{l}\text { Irradiation-assisted } \\
\text { stress corrosion } \\
\text { cracking }\end{array}$ & $\begin{array}{l}\text { Plant-specific operational parameter } \\
\text { monitoring, inspection, evaluation, and } \\
\text { replacement }\end{array}$ & $\begin{array}{l}\text { GE RDE-21-0986; GE } \\
\text { SIL } 157\end{array}$ \\
\hline Control rod drive housing & ss & $\begin{array}{l}\text { Intergranular stress } \\
\text { corrosion cracking }\end{array}$ & $\begin{array}{l}\text { Volumetric examination of welds; VT- } 2 \\
\text { examination of pressure retaining } \\
\text { boundary; system leakage and hydrostatic } \\
\text { tests }\end{array}$ & $\begin{array}{l}\text { ASME Section XI, Sub- } \\
\text { section IWB, examination } \\
\text { categories B-O and B-Pc }\end{array}$ \\
\hline Core shroud head bolts & SS, Alloy 600 & $\begin{array}{l}\text { Intergranular stress } \\
\text { corrosion cracking }\end{array}$ & $\begin{array}{l}\text { Plant-specific ultrasonic examination } \\
\text { during outages; replacement with } \\
\text { crevice-free design }\end{array}$ & GE SIL 433 \\
\hline Core spray sparger & SS & $\begin{array}{l}\text { Intergranular stress } \\
\text { corrosion cracking }\end{array}$ & $\begin{array}{l}\text { Visual inspection during refueling } \\
\text { outages; analytical evaluation; repair }\end{array}$ & IE Bulletin 80-13 \\
\hline \multirow[t]{2}{*}{ Monitor tubes } & \multirow[t]{2}{*}{ ss } & $\begin{array}{l}\text { Intergranular stress } \\
\text { corrosion cracking }\end{array}$ & \multirow{2}{*}{$\begin{array}{l}\text { Visual inspection; leakage monitoring; } \\
\text { Replace with crevice-free design and } \\
\text { resistant material }\end{array}$} & \multirow[t]{2}{*}{ GE SIL 409} \\
\hline & & $\begin{array}{l}\text { Irradiation-assisted } \\
\text { stress corrosion } \\
\text { cracking }\end{array}$ & & \\
\hline Core shroud & ss & $\mathrm{SCC}$ & Replace; add bolts & \\
\hline $\begin{array}{l}\text { Control blades; control } \\
\text { rod drive housing; core } \\
\text { shroud; core shroud head } \\
\text { bolts; core spray internal } \\
\text { piping; core spray } \\
\text { sparger; monitor tubes; jet } \\
\text { pump; orificed fuel } \\
\text { support; steam dryer } \\
\text { support bracket }\end{array}$ & $\begin{array}{l}\text { SS, CASS; } \\
\text { Alloy } 600 ; \\
\text { Alloy X-750 }\end{array}$ & Fatigue & $\begin{array}{l}\text { Volumetric examination of welds and } \\
\text { VT- } 2 \text { of pressure-retaining boundary, and } \\
\text { system leakage and hydrostatic test }\end{array}$ & $\begin{array}{l}\text { ASME Section XI, Sub- } \\
\text { section IWB, examination } \\
\text { categories B-O and B-P; } \\
\text { ASME Section III, } \\
\text { NB-3200 }\end{array}$ \\
\hline
\end{tabular}

As for the pressure vessel, higher operating temperatures should retard the rate of radiation embrittlement in the reactor internals and water chemistry management should prevent the initiation of stress corrosion cracks in attachment welds. Accurate records of operating cycles and transients for reactor vessel and internals provide key information required to evaluate fatigue usage factors and can be used to enhance the effectiveness of inspections. Vibration monitoring and trending can assist preventive maintenance planning.

\subsection{References}

American Society of Mechanical Engineers (ASME) Boiler and Pressure Vessel Code, Section III. 1992. Rules for Construction of Nuclear Power Plant Components. American Society of Mechanical Engineers, New York. 
American Society of Mechanical Engineers (ASME) Boiler and Pressure Vessel Code, Section XI. 1992. Rules for In-Service Inspection of Nuclear Power Plant Components. American Society of Mechanical Engineers, New York.

Andresen, P.L., F.P. Ford, S.M. Murphy, and J.M. Perks. 1988. Stress Corrosion Monitoring and Component Life Prediction. EPRI NP-6028-58, Volumes 1 and 2, Electric Power Research Institute, Palo Alto, California.

Andresen, P.L., F.P. Ford, S.M. Murphy, and J.M. Perks. 1990. "State of Knowledge of Radiation Effects on Environmental Cracking in Light Water Reactor Core Materials." In Proceedings of the Fourth International Conference on Environmental Degradation of Materials in Nuclear Power Systems - Water Reactors. National Association of Corrosion Engineers, Houston.

Berge. P.H., and F. de Keroulas. 1989. "The Present Situation Regarding Environmental Degradation of Components in Pressurized Water Reactors." In Proceedings of the 4th International Symposium on Environmental Degradation of Materials in Nuclear Power Systems - Water Reactors. National Association of Corrosion Engineers, Houston.

Causey, A.R., G.J.C. Carpenter, and S.R. McEwen. 1980. "In-Reactor Stress Relaxation of Selected Materials and Alloys at Low Temperatures,"J. Nuclear Materials, 90:216.

Chopra, O.K. 1992. "Thermal Aging of Cast Stainless Steels in LWR Systems: Estimation of Mechanical Properties." In ASME PVP Nuclear Plant Systems/Components Aging Management and Life Extension, 228:79. American Society of Mechanical Engineers, New York.

GE RDE-21-0986. September 1986. REPORT (Rev. 01) on Acceptance Criteria for Control Rod Cracks. GE Nuclear Energy, San Jose, California.

GE Service Information Letter (GE SIL) 465, Supplement 1. April 30, 1993. Jet Pump Mixer Unusual Surface Observations. GE Service Information Letter, GE Nuclear Energy, San Jose, California.

GE Service Information Letter (GE SIL) 157, Rev. 2. September 1981. Control Blade Lifetime. GE Service Information Letter, GE Nuclear Energy, San Jose, California.

GE Service Information Letter (GE SIL) 409, Rev. 1. July 31, 1986. Inspection of SRM/RM Dry Tubes. GE Service Information Letter, GE Nuclear Energy, San Jose, California.

GE Service Information Letter (GE SIL) 433. February 7, 1986. Shroud Head Bolt Cracks. GE Service Information Letter, GE Nuclear Energy, San Jose, California.

GE Service Information Letter (GE SIL) 462S1. February 22, 1984. Shroud Support Access Hole Cover Cracks. GE Service Information Letter, GE Nuclear Energy, San Jose, California.

IE Bulletin 80-13. 1980. Cracking in Core Spray Spargers. U.S. Nuclear Regulatory Commission, Washington, D.C.

Luk, K.H. 1993a. Pressurized-Water Reactor Internals Aging Degradation Study - Phase I. NUREG/CR-6048, U.S. Nuclear Regulatory Commission, Washington, D.C.

Luk, K.H. 1993b. Boiling-Water Reactor Internals Aging Degradation Study-Phase I. NUREG/CR-5754, U.S. Nuclear Regulatory Commission, Washington, D.C.

Mager, T.R. 1990. "Thermal Annealing of an Embrittled Reactor Vessel: Feasibility and Methodology," Nucl. Eng. Design, 124:43.

Nelson, J.L., and P.L. Andresen. 1991. "Review of Current Research and Understanding of Irradiation-Assisted Stress Corrosion Cracking." In Proceedings of the Fifth International Symposium on Environmental Degradation of Materials in Nuclear Power Systems - Water Reactors. National Association of Corrosion Engineers International, Houston. 
Olivera, J.J., and J.L. Pierrey. 1989. "Failure of Inconel X-750 Bolts of Internals of the Chooz-A Nuclear Power Plant." In Proceedings Fourth International Symposium on Environmental Degradation of Materials in Nuclear Power Systems - Water Reactors, pp. 11-12 to 11-31, National Association of Corrosion Engineers International, Houston.

Shah, V.N., and P.E. MacDonald, eds. 1993. Aging and Life Extension of Major Light Water Reactor Components. Elsevier Science Publishers, Amsterdam, The Netherlands.

van Rooyen, D. 1975. "Review of Stress Corrosion Cracking of Inconel 600," Corrosion, 31:327.

Ware, A.G. 1989. "Pressurized Water Reactor Control Rod Drive Mechanisms and Reactor Internals." In Residual Life Assessment of Major Lighr Water Reactor Components - Overview Volume 2, eds. V. N. Shah and P.E. MacDonald. NUREG/CR-4731 (EGG-2469), Volume 2, pp. 105-142, prepared by EG\&G Idaho, Inc., for the U.S. Nuclear Regulatory Commission, Washington, D.C.

Weiss, J.M., and C.W. Mayo. 1991. "Recommendations for Effective Loose Parts Monitoring," Nucl. Eng. Design, 129:121. 


\section{Reactor Coolant Pressure Boundary}

The reactor coolant pressure boundary (RCPB) is defined in 10 CFR 50.2 as those pressure-containing components, such as pressure vessels, piping, pumps, and valves, which are:

(1) Part of the reactor coolant system, or

(2) Connected to the reactor coolant system, up to and including any and all of the following:

(a) The outermost containment isolation valve in system piping which penetrates primary reactor containment,

(b) The second of two valves normally closed during normal reactor operation in system piping which does not penetrate primary reactor containment,

(c) The reactor coolant system safety and relief valves.

For $B W R$, the reactor coolant system extends to and includes the outermost containment isolation valve in the main steam and feedwater piping.

The entire RCPB is composed of leaktight components to ensure that all radioactivity is confined inside the boundary.

The designation of NRC Quality Group A is exclusively reserved for components that are part of the RCPB; these must meet the requirements for ASME Class 1 components as set forth in Section III of the ASME Boiler and Pressure Vessel Code, except where specifically exempted by the provisions of 10 CFR 50.55a.

This chapter is devoted to a review of aging degradation of RCPB components. Individual sections address aging of PWR piping, valves, and fittings; BWR piping, valves, and fittings; coolant pumps; steam generator tubes (PWR); and pressurizers (PWR). Aging degradation of BWR and PWR pressure vessels (including inlet and outlet nozzles) is reviewed in Chapter 2.

\subsection{PWR Piping, Valves, and Fittings}

This section addresses the aging degradation of carbon steel and SS components that comprise the PWR reactor coolant pressure boundary. The review covers piping, pipe fittings, and pressure-containing components of in-line and pressure relief valves, in the reactor coolant, chemical and volume control (CVC), residual heat removal/low-pressure safety injection (RHR/LPSI), and high-pressure safety injection (HPSI) systems, and the safety injection tank/core flood sub-system. The reactor coolant piping contains the high-pressure water that circulates through the reactor core to remove the heat generated by the fission process. The heated water exits from the reactor vessel and passes through the coolant loop piping to the steam generators. Here it gives up heat to the feedwater to generate steam for the turbine generator. The cycle is completed when the water is pumped by the reactor coolant pumps (RCPs) back to the reactor vessel. The nuclear steam supply system (NSSS) of a PWR plant consists of a reactor and 2, 3, or 4 closed coolant loops connected parallel to the reactor vessel, each loop containing 1 or 2 RCPs and a steam generator. The number of loops and the number of RCPs per loop is dependent on the specific plant and the NSSS vendor design. The layout for a typical two-loop CE plant is shown in Figure 4.1. The system is contained entirely within the containment building. The main reactor coolant piping in Westinghouse plants is primarily made of cast SS, while B\&W uses carbon steel with welddeposited SS cladding, and CE uses carbon steel with roll-bonded SS cladding (Shah and MacDonald 1993, p. 150).

The Chemical Volume Control System (CVCS) controls the volume, purity, and boric acid content of the reactor coolant. The CVCS also provides seal injection water for the reactor coolant pumps. A bypass stream of reactor coolant is continuously purified to control the purity of the reactor coolant and the boric acid concentration. The CVCS also supplies emergency boration. 


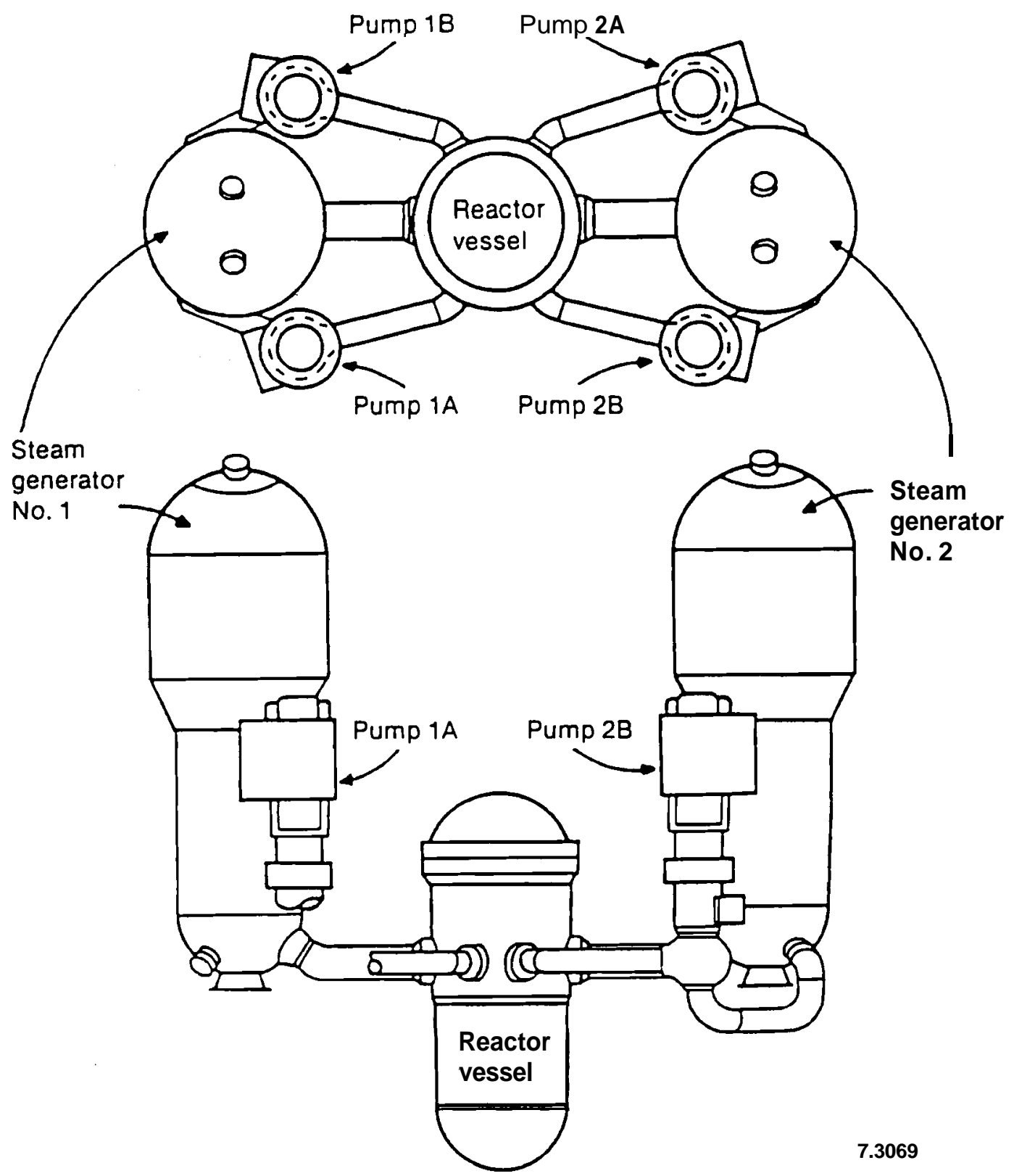

Figure 4.1 Typical two-loop combustion engineering reactor coolant system (Cloud and Server 1987)

The RHR/LPSI system performs several functions during the various states of reactor operation. Its primary functions are to remove heat from the reactor core during normal shutdown and to provide injection cooling of the core during a loss-of-coolant accident (LOCA) and post-LOCA conditions. The RHR/LPSI system generally consists of two trains; however, one Westinghouse plant uses three trains. Each train of the two-train design has a $100 \%$ capacity and is redundant to the other train. The three-traindesigned plant requires two of the three trains to operate in order to accomplish its function. Each train consists of a pump and a heat exchanger with their associated valves. The pumps can be aligned to draw suction from the borated refueling water storage tank, the containment sump, or a hot leg (or legs) of the reactor coolant system. 
A diagram of the HPSI system is presented in Figure 4.2; the system is designed to operate during small LOCAs when reactor coolant pressure has not been significantly reduced from normal operating pressures. In this circumstance, the HPSI system injects borated water into the reactor coolant system to provide cooling to limit core damage and fission product release and to ensure an adequate shutdown margin. The HPSI system has two or three redundant trains, depending on the NSSS vendor. A typical train consists of a high-head pump that draws suction from the refueling water storage tank and discharges to the cold legs of the reactor coolant system.

The safety injection tank/core flood subsystem is a passive system that requires no external signal or power source to operate. It is designed to rapidly inject cooling water into the reactor vessel when vessel pressure is reduced by a LOCA; check valves prevent activation until pressure falls below a predetermined level, then nitrogen gas pressure provides the driving force for coolant injection. (The piping is connected to the cold legs or directly into the RPV depending on the NSSS vendor. Both Westinghouse and CE units have cold leg connections; in B\&W units the connections are to the low pressure/core flood penetrations into the RPV.)

\subsubsection{Aging Degradation Concerns and Mechanisms}

Aging degradation concerns and mechanisms for PWR coolant piping are summarized in Table 4.1. The primary mechanisms of concern are thermal embrittlement and fatigue. The reactor coolant piping, valves, and fittings of a number of plants use cast SSs. Although no problems have been reported, there have been two areas of concern for the long-term fracture integrity of cast SS components. These are 1) the substantial loss of fracture toughness caused by thermal aging of cast materials, and 2) the difficulty of using ultrasonic methods to detect cracks in these materials because of their coarse grained microstructures. These factors lead to possible catastrophic fractures due to large flaws dating from either fabrication or from yet unknown forms of service degradation. Should these flaws go undetected for long periods of time, they could propagate and rupture the component if the fracture toughness eventually decreased to a critical level or if the stresses increased above normal levels during a severe accident event such as an earthquake. The thermal embrittlement degradation mechanism causes a loss in tensile ductility (decrease in residual elongation) and increases the DBTT when cast SS is aged at elevated temperatures. The consequence of this factor is a possible failure by brittle fracture (as opposed to ductile rupture) should the piping be subjected to thermal or mechanical shock when operating at a temperature below the DBTT.

Welds generally have a lower initial fracture toughness than the base metal before thermal exposure due to the presence of inclusions or flaws. Generally, the failure is controlled more by the inclusions than by the aging mechanism. However it appears that there may be a synergistic interaction between the embrittled femte phase and inclusions in the shielded metal arc welds that could result in potential problems.

Stress corrosion cracking, corrosion, and erosion/corrosion have not been, and are not expected to become, mechanisms of concern for the internal surfaces of components considered in this section (Shah and MacDonald 1993, pp. 172-173). However, leakage of coolant onto hot external surfaces has resulted in boric acid corrosion; for susceptible material, it could also result in external stress corrosion cracking.

Piping systems in older plants were designed to the Power Piping Code, which did not specifically require fatigue usage evaluation. Furthermore, on-line monitoring of cyclic loading on the piping was not implemented in many plants. Therefore the fatigue evaluations are either non-existent or inaccurate because of inadequate data. Cumulative fatigue usage evaluations per the ASME Boiler and Pressure Vessel Code require that usage factors be calculated for the maximum stress range and for progressively smaller stress ranges and then summed. The largest stress ranges are typically produced by combinations of pressure and thermal transient conditions occurring at different times in the operating history of the plant. Thus the accuracy of the resulting cumulative usage factors is a complex function of the accuracy of the operating history, including normal temperature and pressure cycles, vibratory loads, and stresses imposed by abnormal occurrences (such as water hammer, stratified flow, and seismic events). The fatigue design criterion in the ASME Boiler and Pressure Vessel Code is intended to ensure that safety margins used to design and license the plants are maintained, and the breach of primary pressure boundary is not seriously compromised by fatigue. This criterion requires that the cumulative fatigue usage be below unity. An increase in the value of the cumulative usage factor to values over unity (due to long-term aging) would indicate the likelihood of initiation of fatigue cracks, which would then grow due to the cyclic loadings causing a fatigue failure. 


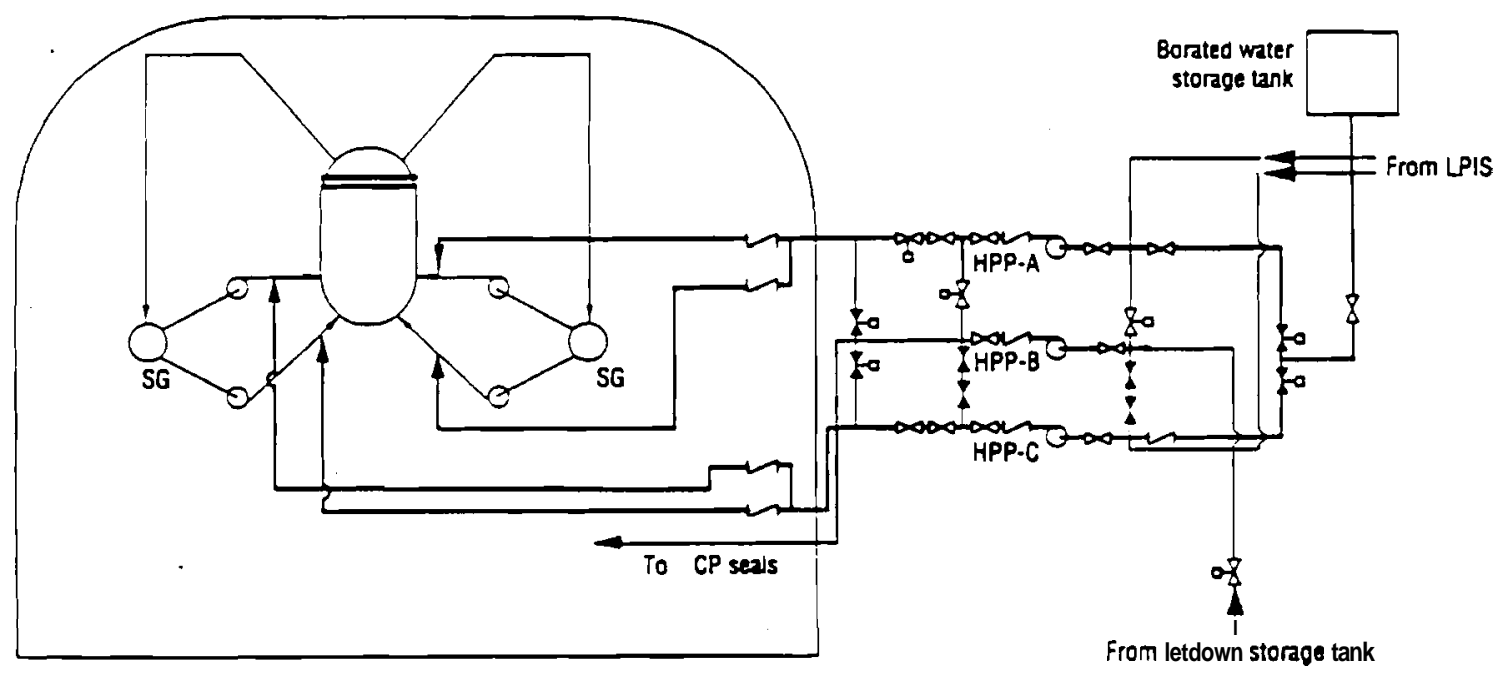

Figure 4.2 Diagram of a PWR high pressure injection system (Blahnik et al. 1992)

Table 4.1 Aging degradation concerns and mechanisms for PWR CPB piping, valves, and fittings

\begin{tabular}{|c|c|c|c|c|}
\hline Components & Materials & Aging Concerns & Aging Mechanisms & References' \\
\hline \multirow{3}{*}{$\begin{array}{l}\text { Reactor Coolant, CVCS, } \\
\text { RHR/LPSI, and HPSI } \\
\text { piping and valves }\end{array}$} & Cast SS & \multirow{2}{*}{$\begin{array}{l}\text { Increase in ductile-to- } \\
\text { brittle transition } \\
\text { temperature }\end{array}$} & \multirow[t]{2}{*}{ Thermal embrittlement } & \multirow[t]{2}{*}{ pp. 161-172 } \\
\hline & $\begin{array}{l}\text { Shielded metal-arc welds in } \\
\text { austenitic SS }\end{array}$ & & & \\
\hline & $\begin{array}{l}\text { Carbon steel with austenitic } \\
\text { SS cladding; Austenitic SS; } \\
\text { Cast SS }\end{array}$ & $\begin{array}{l}\text { Crack initiation and } \\
\text { growth }\end{array}$ & $\begin{array}{l}\text { Thermal and mechanical } \\
\text { fatigue }\end{array}$ & pp. $157-161$ \\
\hline $\begin{array}{l}\text { Safety and relief valve } \\
\text { flanges and bolts }\end{array}$ & Steel & Leakage & $\begin{array}{l}\text { Boric acid corrosion; } \\
\text { Wear }\end{array}$ & \multirow[t]{2}{*}{$\begin{array}{l}\text { Notice 86-108; } \\
\text { Generic Letter 88- } \\
05\end{array}$} \\
\hline \multirow[t]{2}{*}{ Bolts and nuts } & \multirow[t]{2}{*}{ Steel } & Leakage & $\begin{array}{l}\text { Stress relaxation; } \\
\text { corrosion }\end{array}$ & \\
\hline & & $\begin{array}{l}\text { Crack initiation and } \\
\text { growth }\end{array}$ & Stress corrosion cracking & $\begin{array}{l}\text { Bulletin } 89-02 \text {; } \\
\text { Notice 94-55 }\end{array}$ \\
\hline Integral supports & Steel & Loss of support & Fatigue & pp. $157-161$ \\
\hline
\end{tabular}

The original design of the RCPB piping has proven to be adequate to the extent that there have been no failures or reported occurrence of cracking that was attributed to fatigue of RCPB piping. However, this does not guarantee that fatigue damage will continue to be a non-problem for RCPB piping. In general, most of the actual transients including normal shutdowns and scrams result in significantly slower rates of temperature change than specified in the original plant design basis for the RCPB piping. Therefore these transients do not contribute significantly to the overall fatigue damage. However, the fatigue damage in RCPB piping systems can be significantly increased by changes in loading conditions not anticipated in the design phase: flow- and equipment-induced vibrations, stratified flow conditions, and water or steam hammer events. In addition to producing fatigue damage, severe water or steam hammer events have resulted in deformation and cracking of feedwater piping and pipe support structures. 
There have been several instances of corrosion of RCPB components where leakage of primary water resulted in the concentration of boric acid; some of these incidents were reviewed in Notice 86-108, and additional information was provided in Generic Letter 88-05.

Instances of stress corrosion cracking of valve bolting were reviewed in Bulletin 89-02; more recently, SSC of power-operated relief valves has been reported (Notice 94-55). Similar problems have been reported in regard to bolting of reactor coolant pumps (see Section 4.3); in all cases, these degraded components were made of SSs that are very susceptible to stress corrosion cracking.

\subsubsection{Managing Aging Degradation}

A summary of options for managing aging degradation of PWR coolant piping is provided in Table 4.2.

Accurate records, regarding the number, type, and severity of transients that cause fatigue damage, should be maintained and analyzed to estimate remaining fatigue life of the piping. Piping system design, operating procedures, and maintenance practices should be critically examined with the aim of reducing the number and severity of fatigue-producing transients. For example, piping layout should minimize the potential for water hammer or thermal stratification to occur; the causes of flowinduced and mechanical vibrations should be identified and corrected, if possible. Reliability-centered maintenance practices should be instituted to reduce the number and severity of thermal cycles associated with equipment-related shutdowns.

The data needed to determine up-to-date usage factors can in most cases be retrieved from the available records. Detailed data searches need to be completed for individual plants throughout their prior history in order to define the actual transient loading conditions which produce fatigue damage. Although the design Stress Report can potentially identify critical locations in terms of fatigue usages, the calculation of stress ranges for the purpose of updating usages should incorporate changes in the transient conditions and differences in the mechanical constraints in the system in relation to the original design.

Table 4.2 Managing aging degradation of PWR CPB piping, valves, and fittings

\begin{tabular}{|c|c|c|c|c|}
\hline Components & Materials & Aging Mechanisms & Management Options & References \\
\hline \multirow{3}{*}{$\begin{array}{l}\text { Reactor Coolant, } \\
\text { CVCS, RHRILPSI, } \\
\text { and HPSI piping and } \\
\text { valves }\end{array}$} & Cast SS & Thermal embrittlement & Analysis of plant operating & \multirow{3}{*}{$\begin{array}{l}\text { ASME Section } \\
\text { XI, Subsection } \\
\text { IWB and Table } \\
\text { IWB-2500-1 }\end{array}$} \\
\hline & $\begin{array}{l}\text { Shielded metal-arc welds in } \\
\text { austenitic SS }\end{array}$ & & examinations & \\
\hline & $\begin{array}{l}\text { Carbon steel with austenitic SS } \\
\text { cladding; Austenitic SS; Cast } \\
\text { SS }\end{array}$ & $\begin{array}{l}\text { Thermal and mechanical } \\
\text { fatigue }\end{array}$ & $\begin{array}{l}\text { Ultrasonic examination; } \\
\text { Radiographic examination }\end{array}$ & \\
\hline $\begin{array}{l}\text { Safety and relief } \\
\text { valve flanges and } \\
\text { bolts } \\
\end{array}$ & Steel & $\begin{array}{l}\text { Boric acid corrosion } \\
\text { Wear }\end{array}$ & $\begin{array}{l}\text { Visual examination; Ultrasonic } \\
\text { examination; Repair; } \\
\text { Replacement }\end{array}$ & \multirow{3}{*}{$\begin{array}{l}\text { ASME Section } \\
\text { XI, Subsection } \\
\text { IWB and Table } \\
\text { IWB-2500-1 }\end{array}$} \\
\hline Bolts and nuts & Steel & $\begin{array}{l}\text { Stress relaxation; } \\
\text { corrosion; Stress corrosion } \\
\text { cracking }\end{array}$ & $\begin{array}{l}\text { Visual examination; Ultrasonic } \\
\text { examination, Replacement }\end{array}$ & \\
\hline Integral supports & Steel & Fatigue & $\begin{array}{l}\text { Analysis of plant operating } \\
\text { records }\end{array}$ & \\
\hline
\end{tabular}




\subsection{BWR Piping, Valves, and Fittings}

This section addresses aging degradation of carbon steel and SS components that comprise the RCPB of BWRs. The review covers piping, pipe fittings, and pressure-containing components of in-line and pressure relief valves in the recirculation, main steam (MS), feedwater, reactor core isolation cooling (RCIC), residual heat removal/low-pressure coolant injection (RHR/LPCI), high-pressure coolant injection (HPCI), high-pressure core spray (HPCS), and low-pressure core spray (LPCS) systems. Aging degradation of pressure vessels and the pressure-containing components of the recirculation pumps, which are also part of the RCPB, is addressed in Chapter 2 and Section 4.3, respectively.

The BWR recirculation system pumps reactor coolant through the core. This is accomplished by two recirculation loops that are external to the reactor vessel but inside the containment. A constant flow rate is maintained by either variable speed pumps (BWR-3 and BWR-4 designs) or a flow control valve (BWR-5 and BWR-6 designs). A typical recirculation loop (in newer BWRs) contains four motor-operated valves (MOVs) and one hydraulically operated valve, a recirculation pump, and twelve jet pumps (Big Rock Point, Nine Mile Point-1, and Oyster Creek-1 do not have jet pumps). The jet pumps are not part of the RCPB but are addressed in Section 3.2.

A simplified schematic of a typical BWR main steam system is presented in Figure 4.3. The MS system transports steam from the RPV to the turbine generator. Depending on the design, two to four steam lines may be used.

The pressure-containing components of the MS system up to the main steam isolation valves (MSIV) are part of the RCPB; these include the MS lines, the pressure relief valves, and the MSIVs, which are usually pneumatically actuated.

The condensate from the turbines is returned to the RPV by the feedwater system, forming a closed loop during normal operation. Each feedwater line contains two check valves that provide containment isolation and are part of the RCPB. The RCIC system provides makeup water to the RPV during shutdown and when the vessel is isolated from the main condenser. The RCIC system's primary source of water is the condensate storage tank. The secondary source is the suppression pool. Valves may also be aligned to provide water from the RHR/LPCI system. A steam turbinedriven pump draws suction from these three sources and discharges through a shutoff valve into the RPV. Steam to operate the turbine is generated in the RPV by decay heat in the reactor core. The RHRILPCI, HPCI, HPCS, and LPCS are emergency core cooling systems that are designed to mitigate the consequences of postulated emergency situations that could result in core damage and the release of fission products to the environment.

The RHRILPCI system performs several functions during the various states of reactor operation. Its primary function is to remove heat from the reactor core during normal shutdown (shutdown cooling mode), LOCA, and post-LOCA conditions (coolant injection mode). The flow paths for these two modes of operation are shown in Figures 4.4 and 4.5. The RHR/LPCI system may also assist in containment heat removal and containment spray operations.

The BWR-1 through BWR-5 designs use a HPCI system to maintain coolant inventory when the pressure is above that at which the RHR/LPCI or LPCS systems can operate. Water from the condensate storage tank or the suppression pool is pumped through a series of check valves into the feedwater line to the RPV.

In the BWR-6 design, a HPCS system replaces the HPCI system of the older designs. Makeup water is discharged through spray nozzles onto the reactor core, rather than through the feedwater lines.

The function of the LPCS system is to help prevent fuel damage in the event a LOCA occurs that might uncover the reactor core. The system contains a single independent pump that draws suction from the suppression pool and discharges through a series of check valves into the low-pressure spray sparger over the reactor core.

Because of the number of different BWR product lines and variations between plants, this discussion does not describe all the features of each plant. In general, all the equivalent systems described above are included in the aging management of BWRs. For instance, the BWR-2 design incorporated the Emergency Feedwater and Core Spray systems. The BWR-3 design added LPCI. Each generation added or replaced systems that perform the ECCS functions. The equivalent piping/valves/fittings are to be considered for management of aging. All of the functions of the RHR system including Shutdown Cooling and Containment Spray, whether a part of RHR or not, should be subject to a comprehensive aging management program. 


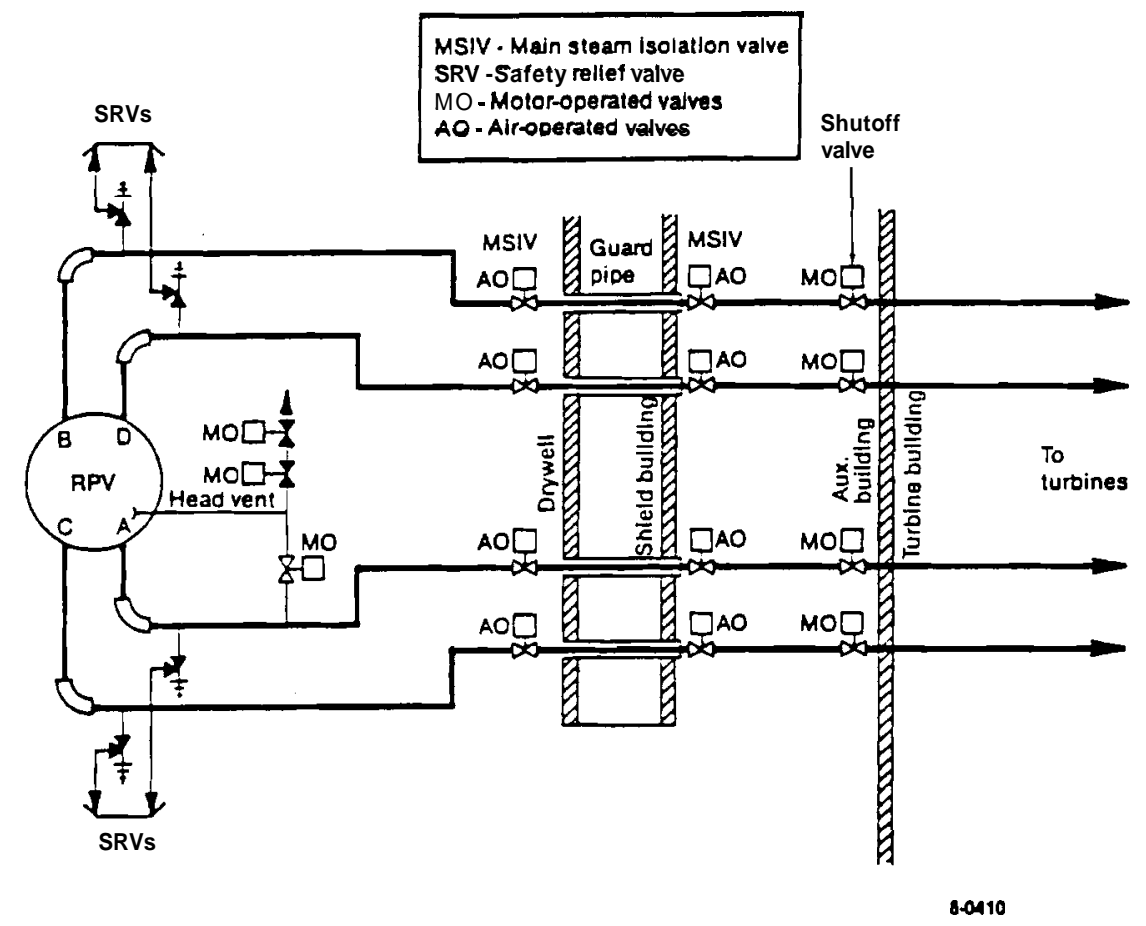

Figure 4.3 Simplified schematic of BWR main steam system (Ware et al. 1989)

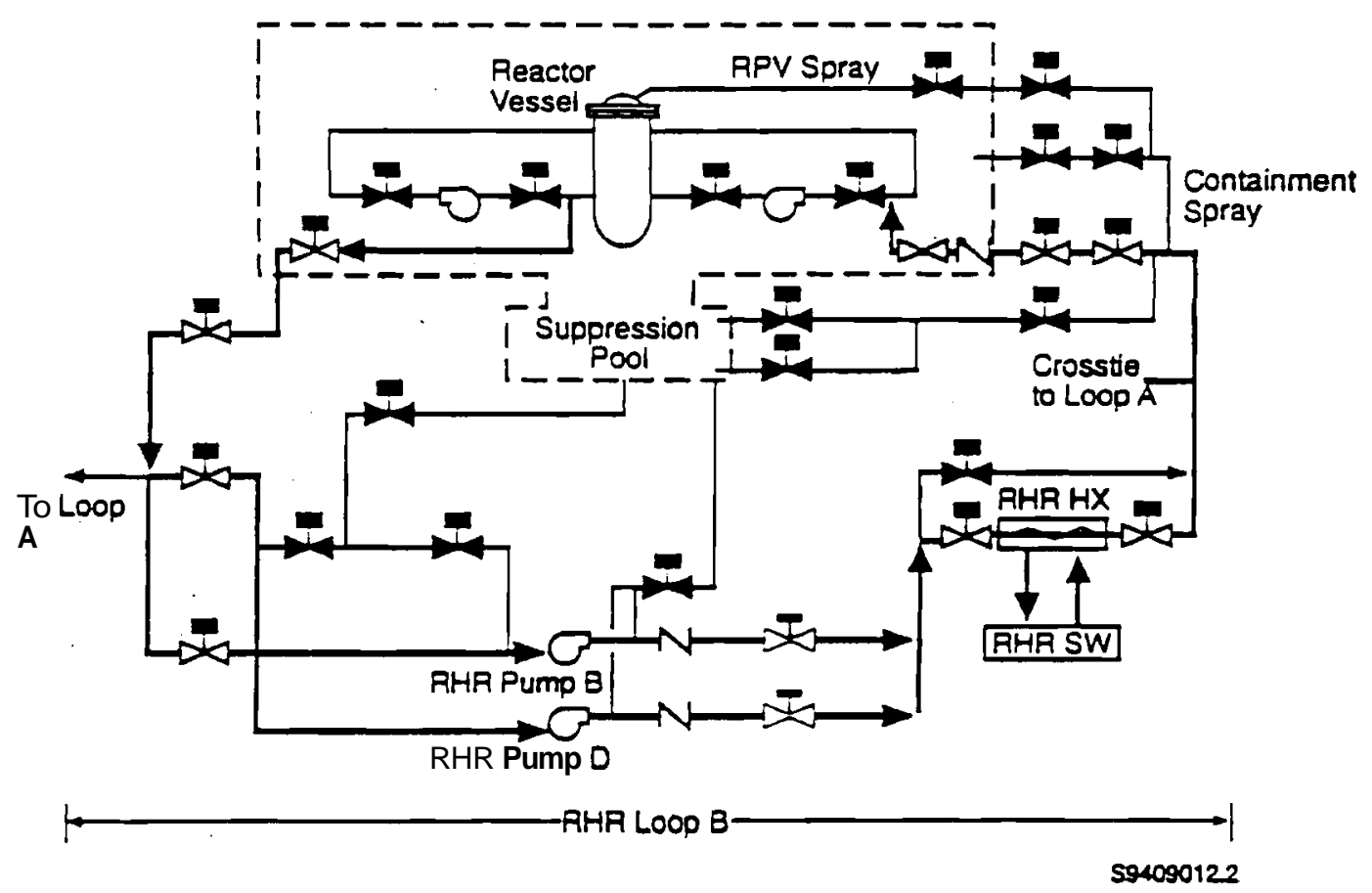

Figure 4.4 Flow path during operation of RHR system in shutdown cooling mode (Lofaro et al. 1989) 


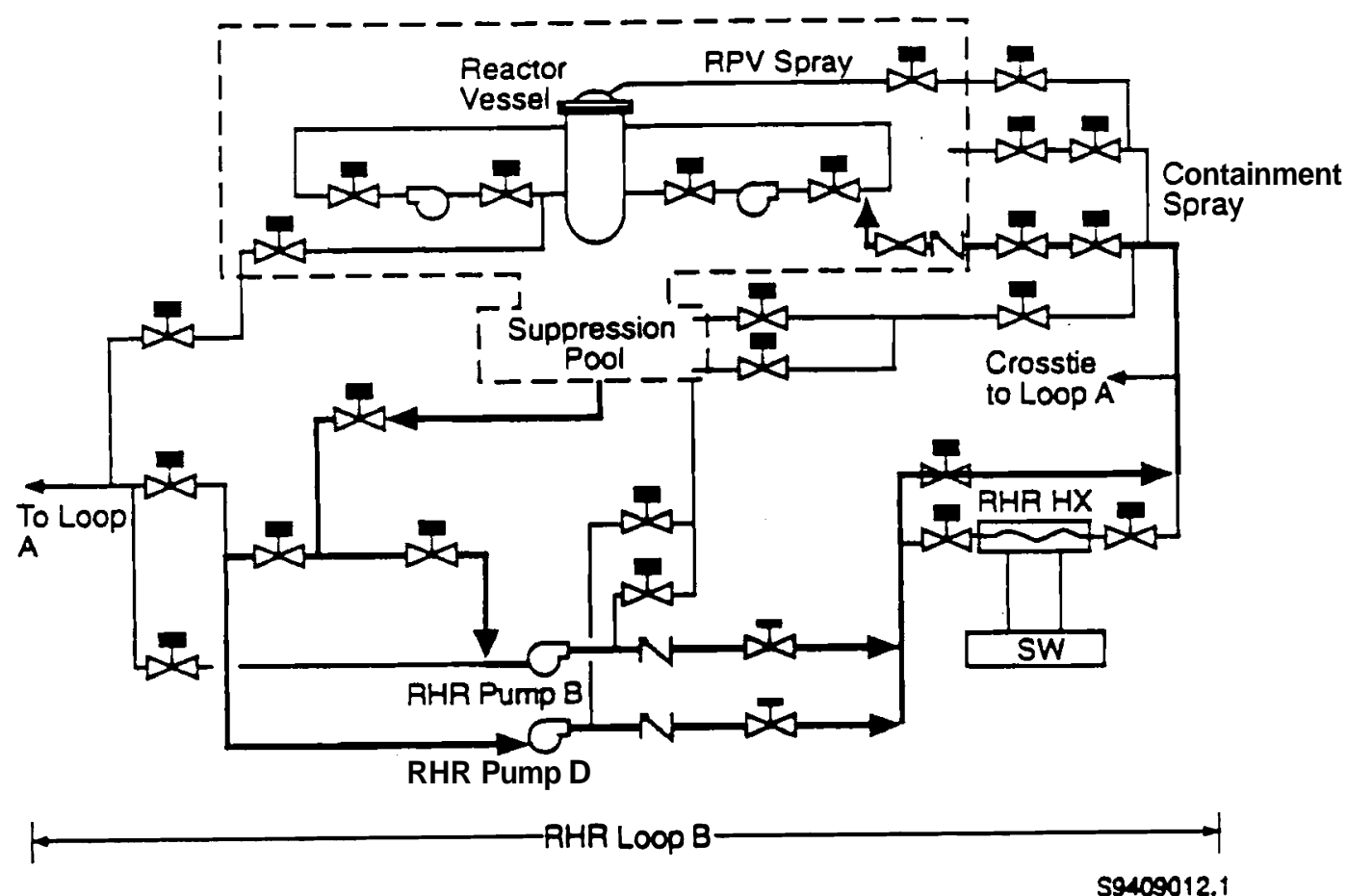

Figure 4.5 Flow path during operation of RHR system in coolant injection mode (Lofaro et al. 1989)

\subsubsection{Aging Degradation Concerns and Mechanisms}

Aging degradation concerns and mechanisms for BWR RCPB piping, valves, and fittings are summarized in Table 4.3. All piping and pipe fittings are either carbon steel or austenitic SS; cast pipe or pipe fittings were not used in BWR RCPB systems.

Wall thinning due to erosion-corrosion has been a major problem for carbon steel pipe in the MS and feedwater systems (Notice 92-35, Notice 93-21). A small section of feedwater piping in LaSalle Unit 1 also developed leaks due to localized erosion; however, this occurrence was due to a design deficiency and should not be of concern at other plants.

Carbon steel piping is also susceptible to degradation from fatigue, primarily due to thermal stratification and flow-induced vibrations. In particular, thermal stratification resulted in several instances of fatigue cracks developing in feedwater piping; the history of these incidents is outlined in Notice 91-38. Thermal fatigue has also resulted in cracking of cast steel valve bodies (Notice 92-50).

Intergranular stress corrosion cracking (IGSCC) of wrought austenitic SS has been a recurring problem for BWRs (Bulletin 8302). Changes in water chemistry, thermal and mechanical treatments to eliminate tensile stress at sensitized surfaces, and replacement of BWR piping with steels that are less susceptible to IGSCC, as recommended by Hazelton and Koo (1988), have eliminated most of the concern. However, the potential still exists for IGSCC to occur under some circumstances, and there is some question as to whether the rate of crack growth is independent of the incubation period.

Transgranular stress corrosion cracking (TGSCC) has not yet been a problem for operating plants; however, laboratory results show that it can be initiated by coolant impurities, and once started, the cracks continue to grow, even in Type $316 \mathrm{NG}$. Therefore, maintaining high water purity is a good preventive practice.

Thermal embrittlement or IGSCC has not caused problems for cast SS valve bodies used in BWR RCPB systems. However, the local femte content can vary over a large range (Bogie et al. 1992) that includes the potential for localized regions with increased ferrite content to undergo an increase in the ductile-to-brittle transition temperature, while other regions with decreased femte content develop IGSCC (Lapides 1991). 
Table 4.3 Aging degradation concerns and mechanisms for BWR CPB piping, valves, and fittings

\begin{tabular}{|c|c|c|c|c|}
\hline Components & Materials & Aging Concerns & Aging Mechanisms & References' \\
\hline $\begin{array}{l}\text { MS and FW pipe and in- } \\
\text { line valves }\end{array}$ & $\begin{array}{l}\text { Carhon } \\
\text { steel }\end{array}$ & Wall thinning & Erosion-corrosion & $\begin{array}{l}\text { p. 680; Notice 92-35; Notice } \\
\text { 93-21 }\end{array}$ \\
\hline $\begin{array}{l}\text { MS, FW, RCIC, } \\
\text { RHR/LPCI, HPCI, HPCS, } \\
\text { and LPCS pipe and in-line } \\
\text { valves }\end{array}$ & $\begin{array}{l}\text { Carbon } \\
\text { steel }\end{array}$ & $\begin{array}{l}\text { Crack initiation and } \\
\text { growth }\end{array}$ & $\begin{array}{l}\text { Fatigue due to thermal } \\
\text { transients, vibration, and } \\
\text { pressure }\end{array}$ & $\begin{array}{l}\text { pp. 805-811; Notice 91-38; } \\
\text { Notice } 92-50\end{array}$ \\
\hline \multirow{2}{*}{$\begin{array}{l}\text { Recirculation; RHR/LPCI, } \\
\text { HPCS, and LPCS pipe and } \\
\text { valves }\end{array}$} & \multirow{2}{*}{$\begin{array}{l}\text { Austenitic } \\
\text { SS; Cast SS } \\
\text { valves }\end{array}$} & $\begin{array}{l}\text { Crack initiation and } \\
\text { growth }\end{array}$ & $\begin{array}{l}\text { Intergranular stress corrosion } \\
\text { cracking }\end{array}$ & pp. 679-680; Bulletin 83-02 \\
\hline & & $\begin{array}{l}\text { Crack initiation and } \\
\text { growth }\end{array}$ & $\begin{array}{l}\text { Transgranular stress } \\
\text { corrosion cracking }\end{array}$ & p. 680 \\
\hline \multirow[t]{2}{*}{$\begin{array}{l}\text { Recirculation, RHR/LPCI, } \\
\text { HPCS, and LPCS valves }\end{array}$} & \multirow[t]{2}{*}{ Cast SS } & $\begin{array}{l}\text { Crack initiation and } \\
\text { growth }\end{array}$ & Thermal fatigue & pp. 805-811 \\
\hline & & $\begin{array}{l}\text { Increase in ductile-to- } \\
\text { brittle transition } \\
\text { temperature }\end{array}$ & Thermal embrittlement & \multirow[t]{2}{*}{ pp. 680-681 } \\
\hline Valve flanges & Steel & Leakage & Wear & \\
\hline Nuts and bolts & $\begin{array}{l}\text { Carbon } \\
\text { steel }\end{array}$ & Leakage & Stress relaxation & \multirow[t]{2}{*}{-- } \\
\hline Integral supports & Steel & $\begin{array}{l}\text { Crack initiation and } \\
\text { growth }\end{array}$ & $\begin{array}{l}\text { Thermal and mechanical } \\
\text { fatigue }\end{array}$ & \\
\hline
\end{tabular}

Leakage due to wear, of valve flanges or stress relaxation in nuts and bolts can result in leakage of the primary reactor coolant; if molybdenum disulfide is present as a lubricant, hydrogen sulfide can be produced and result in stress corrosion cracking of the bolting.

\subsubsection{Managing Aging Degradation}

The options for managing aging degradation of BWR coolant piping are summarized in Table 4.4. Shah and MacDonald (1993) have extensively reviewed the options (countermeasures) for managing aging degradation due to IGSCC in BWR RCPB piping. These options include materials-related remedies, such as solution heat treating and application of a corrosion-resistant coating (which can be done in the field); various stress-related remedies that reduce the tensile stresses in the HAZs of welds; the application of hydrogen water chemistry to reduce the electrochemical potential that drives IGSCC; temporary repair actions; and replacement of degraded piping. Hazelton and Koo (1988) provide the technical basis for NRC guidance and recommendations for controlling IGSCC, detecting and evaluating pipe cracks, repair methods, and replacement of deteriorated piping. The NRC position is formally set forth in Generic Letter 88-01.

Accurate records, regarding the number, type, and severity of transients that cause fatigue damage, should be maintained and analyzed to estimate the remaining fatigue Life of the piping. Piping system design, operating procedures, and maintenance practices should be critically examined with the aim of reducing the number and severity of fatigue-producing transients. For example, piping layout should minimize the potential for water hammer or thermal stratification to occur; the causes of flowinduced and mechanical vibrations should be identified and corrected, if possible; and reliability-centered maintenance practices can reduce the number and severity of thermal cycles associated with equipment-related shutdowns. 
Table 4.4 Managing aging degradation in BWR CPB piping, valves, and fittings

\begin{tabular}{|c|c|c|c|c|}
\hline Components & Materials & Aging Mechanisms & Management Options & References' \\
\hline MS and feedwater pipe & Carbon steel & Erosion-corrosion & $\begin{array}{l}\text { Ultrasonic examinations; } \\
\text { Radiography }\end{array}$ & $\begin{array}{l}\text { pp. 815-818; } \\
\text { Wu 1989, Appendix } \\
\text { A }\end{array}$ \\
\hline $\begin{array}{l}\text { MS and feedwater in-line } \\
\text { valves }\end{array}$ & Carbon steel & Erosion-corrosion & Visual examination & ASME Section XI \\
\hline $\begin{array}{l}\text { MS, Feedwater. RCIC, } \\
\text { RHR/LPCI, HPCI, HPCS, } \\
\text { and LPCS pipe and in-line } \\
\text { valves }\end{array}$ & Carbon steel & $\begin{array}{l}\text { Fatigue due to thermal } \\
\text { transients, vibration, and } \\
\text { pressure }\end{array}$ & $\begin{array}{l}\text { Analysis of records of transients; } \\
\text { Minimize transients; Ultrasonic } \\
\text { examinations }\end{array}$ & pp. $815-818$ \\
\hline \multirow[t]{2}{*}{$\begin{array}{l}\text { Recirculation, RHR/LPCI, } \\
\text { HPCS, and LPCS pipe and } \\
\text { valves }\end{array}$} & \multirow[t]{2}{*}{$\begin{array}{l}\text { Austenitic SS: } \\
\text { Cast SS valves }\end{array}$} & $\begin{array}{l}\text { Intergranular stress corrosion } \\
\text { cracking }\end{array}$ & $\begin{array}{l}\text { Materials-related remedies; } \\
\text { Stress-related remedies; } \\
\text { Hydrogen water chemistry; } \\
\text { Temporary repairs; } \\
\text { Replacement; Ultrasonic } \\
\text { examination*' }\end{array}$ & $\begin{array}{l}\text { pp. 691-712; } \\
\text { Hazelton and Koo } \\
\text { 1988; Generic Letter } \\
88-01\end{array}$ \\
\hline & & $\begin{array}{l}\text { Transgranular stress corrosion } \\
\text { cracking }\end{array}$ & $\begin{array}{l}\text { Hydrogen water chemistry; } \\
\text { impurity control; Ultrasonic } \\
\text { examination }\end{array}$ & pp. $714-715$ \\
\hline \multirow[t]{2}{*}{$\begin{array}{l}\text { Recirculation, RHR/LPCI, } \\
\text { HPCS, and LPCS valves }\end{array}$} & \multirow[t]{2}{*}{ Cast SS } & Thermal fatigue & $\begin{array}{l}\text { Analysis of plant operating } \\
\text { records }\end{array}$ & \\
\hline & & Thermal embrittlement & $\begin{array}{l}\text { Analysis of plant operating } \\
\text { records; Test specimens }\end{array}$ & pp. $680-681$ \\
\hline Valve flanges & Steel & Wear & $\begin{array}{l}\text { Visual examination; Repair; } \\
\text { Replacement }\end{array}$ & \multirow[t]{3}{*}{$\begin{array}{l}\text { ASME Section XI, } \\
\text { Table IWB-2500-1 }\end{array}$} \\
\hline Nuts and bolts & Carbon steel & Stress relaxation & $\begin{array}{l}\text { Visual examination; Ultrasonic } \\
\text { examination; Replacement }\end{array}$ & \\
\hline Integral supports & Steel & $\begin{array}{l}\text { Thermal and mechanical } \\
\text { fatigue }\end{array}$ & $\begin{array}{l}\text { Analysis of plant operating } \\
\text { records }\end{array}$ & \\
\hline
\end{tabular}

The data needed to determine up-to-date usage factors can, in most cases, be retrieved from the available records. Detailed data searches need to be completed for individual plants throughout their prior history in order to define the actual transient loading conditions which produce fatigue damage. Although the design Stress Report can potentially identify critical locations in terms of fatigue usage, the calculation of stress ranges for the purpose of updating fatigue usage should incorporate changes in the transient conditions and differences in the mechanical constraints in the system in relation to the original design.

Replacement of carbon steel piping components with low alloy or low carbon grade austenitic SS has been used successfully to mitigate erosion-corrosion.

The initiation of TGSCC can be prevented by the application of hydrogen water chemistry and the strict control of impurities.

The effects of thermal embrittlement and IGSCC on cast SS components can be predicted if plant operating records have been maintained in sufficient detail; Chopra (1994) reviewed the fracture properties of thermally-aged cast SSs and derived correlations that can be used to predict Charpy-impact energy and fracture toughness from known material information, time, and 
service temperature. Chopra and Shack (1994) present the correlations and procedures recommended by Chopra (1994) in a concise, easy-to-use form. Examination of test specimens from cast SS components (such as valve bodies and piping elbows) can be used to confirm predictions.

\subsection{Reactor Coolant Pumps}

The RCPs circulate the primary coolant water through the reactor coolant system. All of the pumps are of the single stage, single suction, centrifugal design, with the motor mounted above the pump. The three general types of coolant pumps are illustrated in Figures 4.6, 4.7, and 4.8. All BWR recirculation pumps are known as Type C, while PWR primary coolant pumps are either Type $\mathrm{E}$ or Type $\mathrm{F}$. The major design difference is that Type $\mathrm{F}$ pumps have thicker walls than Types $\mathrm{C}$ or $\mathrm{E}$; additional detail on pump design is given in Chapter 10 of Shah and MacDonald (1993).

In general, CE plants use Type E pumps, Westinghouse plants use Westinghouse-manufacturedType F pumps, while B\&W plants may use either Type E or Type F pumps: Drahos et al. (1989) provide a comprehensive listing of the type of pump used in each nuclear plant in the United States. Subcomponents that are part of the RCPB are the pump casing, cover, nozzles, seal flange, seal-cooling heat exchanger, and the closure studs and nuts.

Type F pump casings have high residual stresses at the welds and low stresses in the base metal; Types $\mathrm{C}$ and $\mathrm{E}$ have high residual stresses in both the welds and in the base metal. There is a potential for cracks to develop at the interior surface of the pump body under the combined effects of residual stresses and fatigue; however, design of the pump bodies is generally considered to be very conservative from a fatigue standpoint.

\subsubsection{Aging Degradation Concerns and Mechanisms}

The aging degradation concerns and mechanisms for those components of the RCPs that are part of the RCPB are summarized in Table 4.5.

The casings and covers of RCPs are fabricated from either static-cast SS or carbon steel that is internally clad with SS. Cast SS pump sections are joined by welding with femtecontrolled filler material. Cast austenitic-ferritic (duplex) SS loses ductility (becomes more brittle), but also gains strength, when aged at elevated temperatures. The mechanism that produces these changes, which occurs slowly at normal LWR coolant temperatures, is referred to as thermal embrittlement. Thermal embrittlement results in an increase in the DBTT of duplex SSs. The primary concern is that, if the pump casing is subjected to a thermal or mechanical shock when it is operating at a temperature below the DBTT, it may fail by brittle fracture, instead of yielding in a ductile mode.

Cast SS pump casings are susceptible to IGSCC in BWRs if the femte content is low. The local ferrite content can vary over a large range (Bogie et al. 1992); thus, it is possible that localized regions may be deficient in femte content. Indeed, Lapides (1991) reported the occurrence of localized IGSCC under normal BWR conditions. Type C pump casings receive a full solution anneal; this heat treatment reduces sensitization of heat-affected zones near the welds. However, if repair welding is later performed, the weld zones may also be susceptible to IGSCC.

Closure studs bolt the coolant pump cover to the casing. In PWRs, if the gasket leaks, the reactor coolant can cause boric acid corrosion of the closure studs, which are made of low-alloy steel; there have also been instances where this leakage has resulted in stress corrosion cracking of bolts that were fabricated of Alloy A-286, an alloy that is particularly susceptible to stress corrosion cracking (Notice 90-68).

Coolant pump internals are susceptible to high-cycle mechanical and thermal fatigue. Failure of the pump internals will not compromise the integrity of the pressure boundary, but broken pieces could be carried into the RPV and cause damage to the reactor internals. 


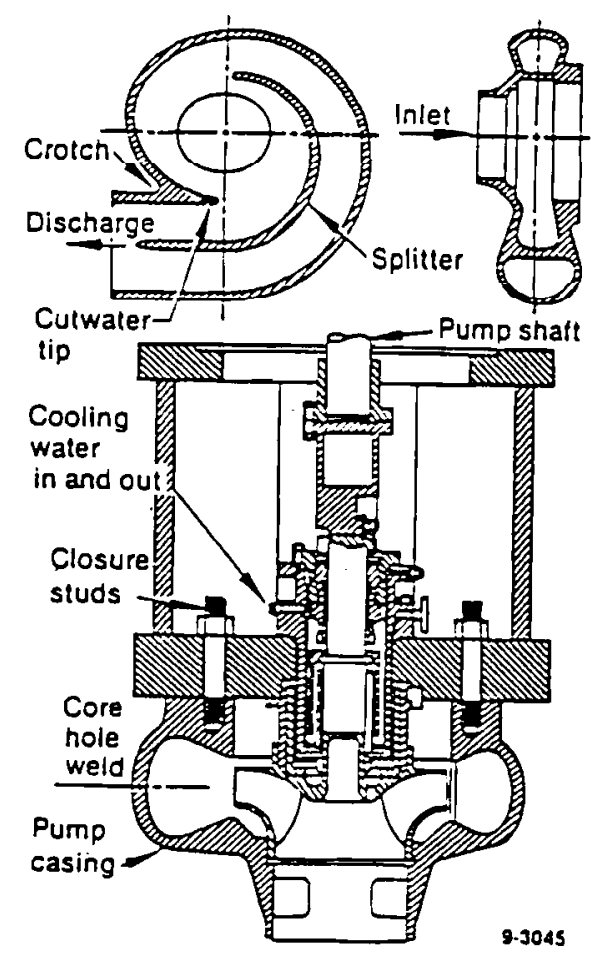

Figure 4.6 BWR Type $C$ reactor coolant pump (Jaske and Shah 1990)
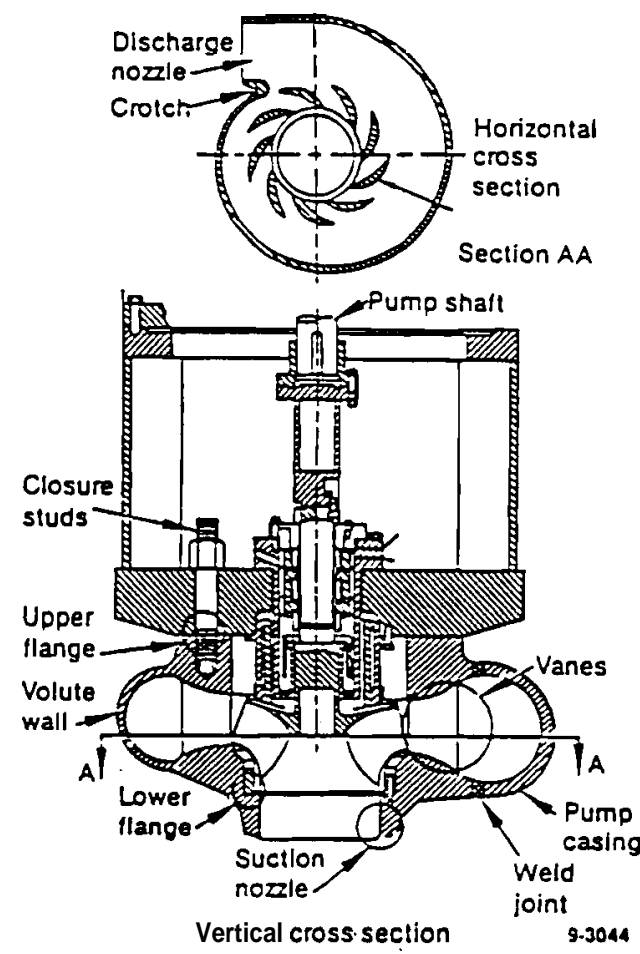

Figure 4.7 PWR Type E reactor coolant pump (Jaske and Shah 1990)
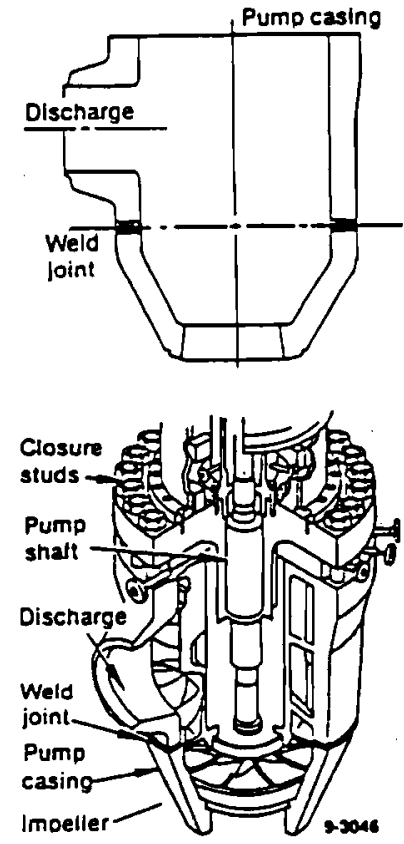

Figure 4.8 PWR Type F reactor coolant pump (Jaske and Shah 1990) 
Table 4.5 Aging degradation concerns and mechanisms for reactor coolant pumps

\begin{tabular}{|c|c|c|c|c|}
\hline Components & Materials & Aging Concerns & Aging Mechanisms & $\begin{array}{c}\text { Reference } \\
\mathbf{s}^{\mathbf{n}}\end{array}$ \\
\hline \multirow[t]{4}{*}{$\begin{array}{l}\text { Pump casing; } \\
\text { Cover }\end{array}$} & Cast SS & $\begin{array}{l}\text { Increase in ductile-to-brittle transition } \\
\text { temperature }\end{array}$ & Thermal embrittlement & $\begin{array}{l}\text { pp. 355- } \\
356\end{array}$ \\
\hline & \multirow{3}{*}{$\begin{array}{l}\text { Cast SS: } \\
\text { Carbon steel } \\
\text { with SS } \\
\text { cladding }\end{array}$} & $\begin{array}{l}\text { Crackıng at positions having high } \\
\text { residual stress (Types C and E pump } \\
\text { casings) }\end{array}$ & $\begin{array}{l}\text { Thermal and mechanical } \\
\text { fatigue }\end{array}$ & $\begin{array}{l}\text { pp. 356- } \\
360\end{array}$ \\
\hline & & $\begin{array}{l}\text { Crack initiation and growth in Type C } \\
\text { (BWR) pump casings }\end{array}$ & $\begin{array}{l}\text { Intergranular stress corrosion } \\
\text { cracking }\end{array}$ & $\begin{array}{l}\text { pp. 360- } \\
361\end{array}$ \\
\hline & & Wastage (PWR only) & Boric acid corrosion & p. 360 \\
\hline Heat exchanger & Steel & $\begin{array}{l}\text { Cracking at positions having high } \\
\text { residual stress (Types C and E pump } \\
\text { casings) }\end{array}$ & Thermal fatigue & -- \\
\hline Seal flange & Steel & Leakage & Wear & \\
\hline \multirow{2}{*}{$\begin{array}{l}\text { Closure studs and } \\
\text { nuts }\end{array}$} & \multirow{2}{*}{$\begin{array}{l}\text { Low-alloy } \\
\text { steel }\end{array}$} & Leakage & Stress relaxation & \\
\hline & & Bolting failure & $\begin{array}{l}\text { Boric acid corrosion (PWR } \\
\text { pumps only); Stress corrosion } \\
\text { cracking }\end{array}$ & $\begin{array}{l}\text { p. } 360 ; \\
\text { Notice } 90- \\
68\end{array}$ \\
\hline
\end{tabular}

\subsubsection{Managing Aging Degradation}

Options for managing aging degradation of RCPs are summarized in Table 4.6.

Table 4.6 Managing aging degradation of reactor coolant pumps

\begin{tabular}{|c|c|c|c|c|}
\hline Components & Materials & Aging Mechanisms & Management Options & References \\
\hline \multirow{4}{*}{$\begin{array}{l}\text { Pump casing; } \\
\text { Cover }\end{array}$} & Cast SS & Thermal embrittlement & \multirow[t]{5}{*}{ Visual examination } & \multirow{5}{*}{$\begin{array}{l}\text { Shah and MacDonald 1993, pp. } \mathbf{3 6 2 -} \\
\mathbf{3 6 5} \text {; } \\
\text { Guy 1990; } \\
\text { ASME Section XI, Table IWB-2500-1 }\end{array}$} \\
\hline & \multirow{3}{*}{$\begin{array}{l}\text { Cast SS; } \\
\text { Carbon steel } \\
\text { with SS } \\
\text { cladding }\end{array}$} & Fatigue & & \\
\hline & & $\begin{array}{l}\text { Intergranular stress corrosion } \\
\text { cracking }\end{array}$ & & \\
\hline & & Boric acid corrosion & & \\
\hline $\begin{array}{l}\text { Heat } \\
\text { exchanger }\end{array}$ & Steel & Thermal fatigue & & \\
\hline Seal flange & Steel & Wear & $\begin{array}{l}\text { Visual examination; } \\
\text { Repair }\end{array}$ & ASME Section XI, Table IWB-2500-1 \\
\hline \multirow{2}{*}{$\begin{array}{l}\text { Closure studs } \\
\text { and nuts }\end{array}$} & \multirow{2}{*}{$\begin{array}{l}\text { Low-alloy } \\
\text { steel }\end{array}$} & Stress relaxation & \multirow{2}{*}{$\begin{array}{l}\text { Visual examination; } \\
\text { Ultrasonic examination; } \\
\text { Replacement }\end{array}$} & \\
\hline & & $\begin{array}{l}\text { (PWR) Boric acid corrosion; } \\
\text { SCC }\end{array}$ & & \\
\hline
\end{tabular}


Conventional ultrasonic inspection techniques are not capable of reliably detecting cracks in the pump bodies and internals because of the large grain size and the elastic anisotropy caused by different grain structures in the casings. Likewise, current radiographic techniques have not proven reliable for detecting cracks in the casing welds, and vibration monitoring techniques have not been capable of detecting high-cycle fatigue cracks early enough to avoid unscheduled outages. Thus, visual examination of exterior and interior surfaces during routinely scheduled inspections remains the most reliable method for detecting cracks in these components. Chopra and Shack (1994) present the correlations and procedures recommended by Chopra (1994) in a concise, easy-to-use form. Egan et al. (1987) reviewed inservice inspection techniques, and Jeong and Ammirato (1988) reviewed the use of ultrasonic techniques for the examination of welds in cast SS pump bodies.

Closure studs can be visually inspected; however, the ultrasonic cylindrically guided wave technique is capable of reliably detecting (but not sizing) both corrosion wastage and flaws that are well below the critical crack size (Light et al. 1986; Liu 1993).

\subsection{Steam Generator (PWR)}

This section addresses the aging degradation of Alloy 600 tubes in PWR steam generators.

In PWRs, the hot primary coolant water is circulated through the steam generator tubes and heats the secondary-system water to make steam that drives the turbine generators. The two types of steam generators in use for PWR plants are illustrated in Figures 4.9 and 4.10. Westinghouse and CE plants use recirculating steam generators (RSG), which generally convert about $25 \%$ of the secondary water to steam during each pass through the generators; the remainder of the water is recirculated. Babcox and Wilcox plants use once-through steam generators (OTSG) from which only steam exits on the secondary side.

The design of the steam generators confines radionuclides from neutron activation or damaged fuel within the RCPB during normal operation. However, if a tube leaks the flow is from the primary side to the secondary side, and rupture of a tube could cause the release of radioactivity to the environment. Moreover, the sudden failure of several tubes could result in depressurization of the RCPB.

Except for recently manufactured steam generators, all tubing was made from nickel-based Alloy 600. However, as discussed by Shah and MacDonald (1993, pp. 252-255), differences in processing details and manufacturing methodologies that were employed by the different manufacturers (and even by the same manufacturer at different periods) can significantly affect the response of the material to a given environment. Moreover, the fact that some of these differences may still be held as trade secrets complicates the task of generalizing variables that are of universal importance to an understanding of the material's behavior.

\subsubsection{Aging Degradation Concerns and Mechanisms}

The aging degradation concerns and mechanisms for PWR steam generator tubes are summarized in Table 4.7.

Primary water stress corrosion cracking (PWSCC) has been observed only in Westinghouse RSGs. However, most of the affected steam generator tubes had been given a relatively low-temperature mill-anneal; tubing used in CE and B\&W steam generators was given a higher-temperature mill-anneal, which makes them more resistant to PWSCC; however, PWSCC may become of increasing importance as the plants continue to age. Stress corrosion cracking also occurred on the primary side of OTSGs in Three Mile Island, Unit 1; however, this is believed to have been caused by contamination of the primary-side water (Shah and MacDonald 1993, pp. 288-289). There are two principal types of intergranular corrosion that occur on the secondary-waterside of PWR steam generators: intergranular attack (IGA) and IGSCC. Both high-temperature and lowtemperature mill-annealed tubes have been affected by these mechanisms; however, to date, IGA and IGSCC have not been a problem for thermally treated tubes.

Denting is the plastic deformation of tubes resulting from the buildup of carbon steel support plate corrosion products (magnetite) in tube-to-tube support plate annuli. The buildup of nonprotective corrosion product oxides, consisting mainly of iron oxide (magnetite), leads directly to tube distortion at the support plate intersections and to distortion and cracking of the support plates. The tube distortions at the support plate intersections have resulted in numerous instances of tube leaks caused by stress corrosion cracks initiated primarily from the inside (primary side) surface of the dented tube. 


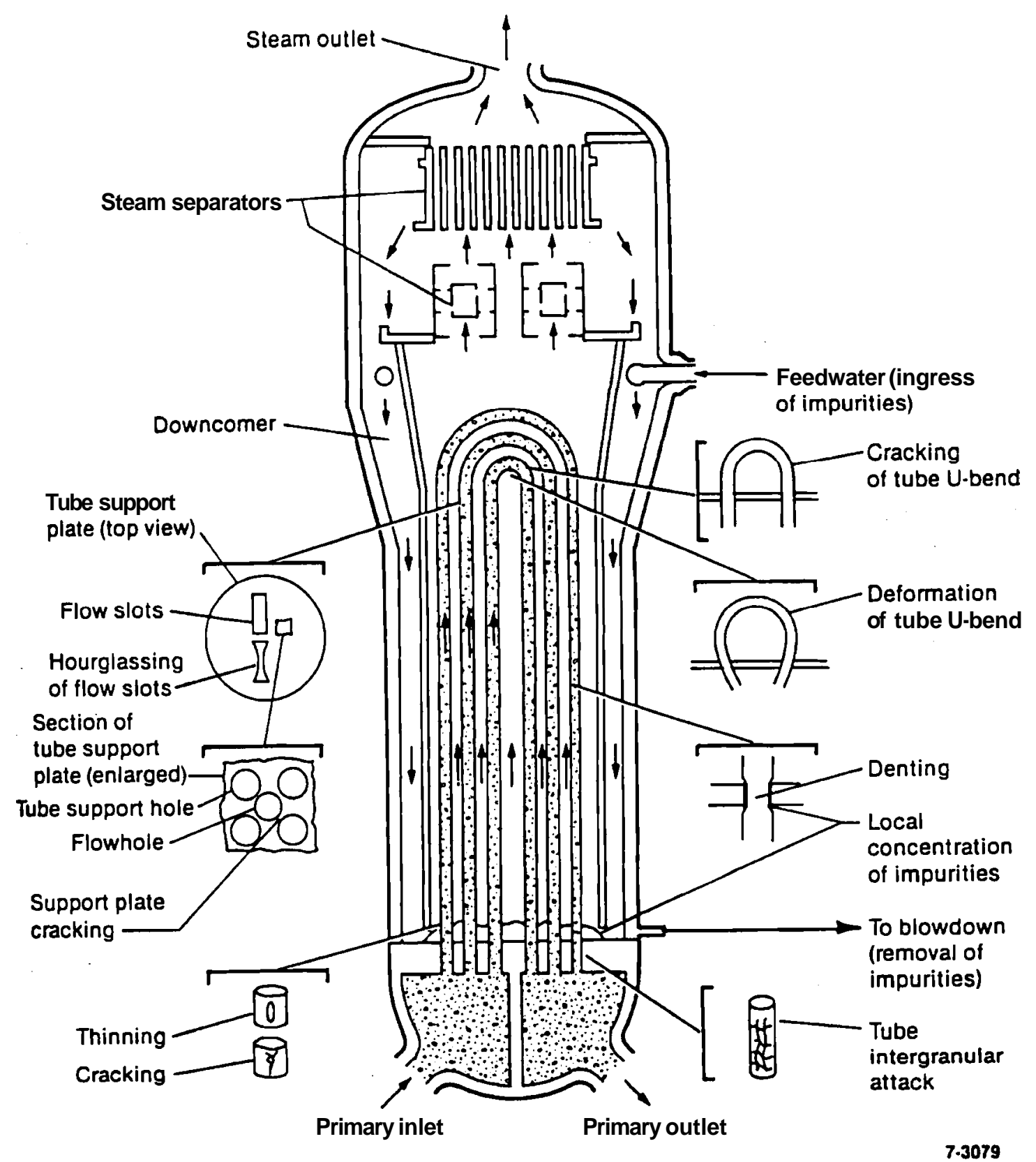

Figure 4.9 Schematic of recirculating steam generator with problem areas indicated (Malhotra 1987)

Unlike most degradation mechanisms, denting usually affects large numbers of tubes at approximately the same time. The buildup and expansion of corrosion products occurs over an extended period of time, but deformation of the tubes occurs in a short period of time. The primary concern is that even small dents can induce large tensile stresses in the tubes and initiate IGSCC or PWSCC during subsequent operation.

Pitting is another steam generator tube aging mechanism. Once initiated, pitting can rapidly spread and result in through-wall penetration within a few operating cycles, resulting in transfer of radionuclides to the secondary-water system. This is not, however, considered a significant safety hazard because leakage is detected long before catastrophic failure could occur. 


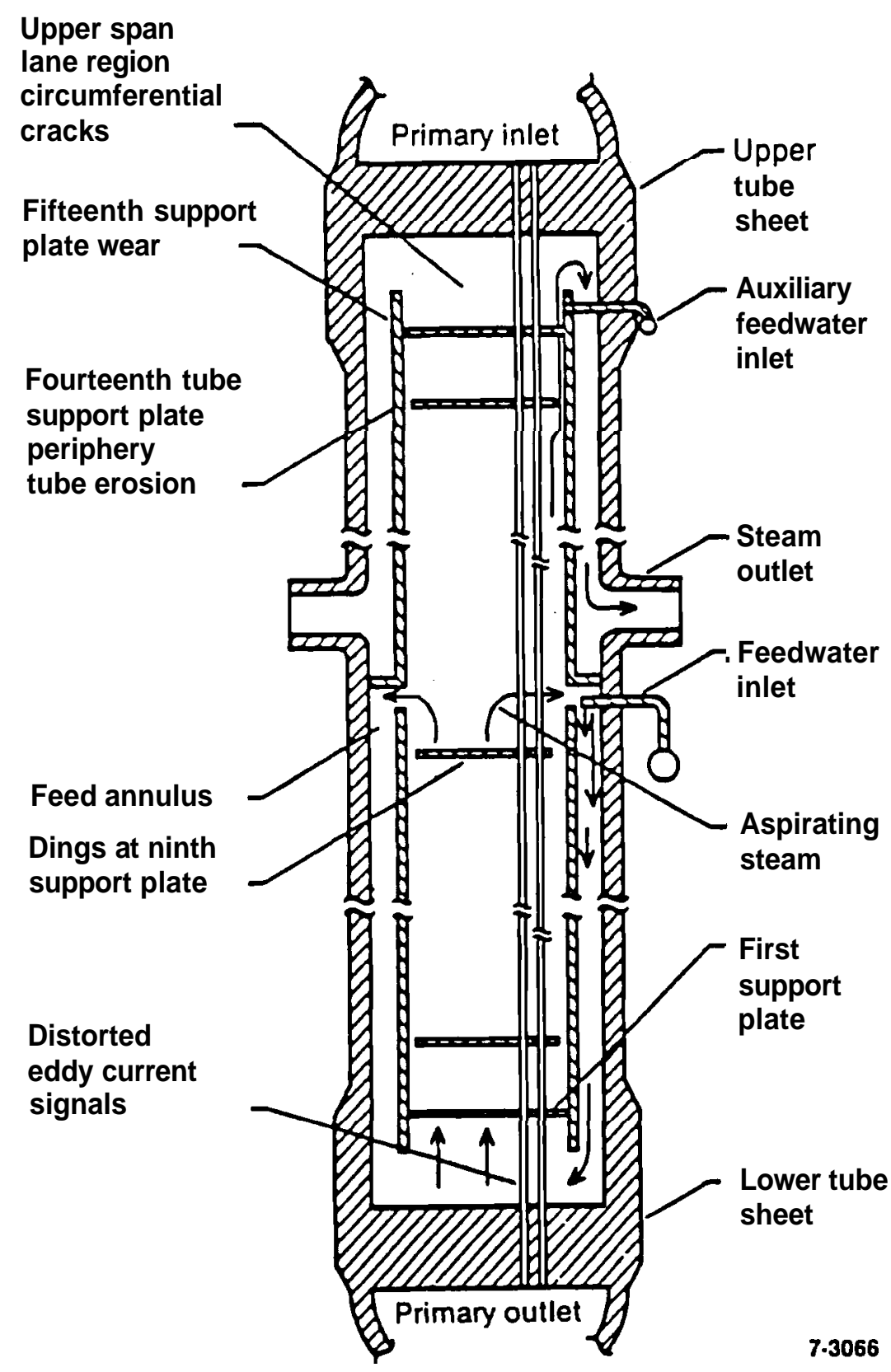

Figure 4.10 Schematic of once-through steam generator with problem areas indicated (Malhotra 1987)

Fretting has caused operational problems for many plants with RSGs. The fretting (wear) is caused by mechanical vibration, and results in thinning of tube walls where they contact parts of the support structure. There are concerns that vibration and wear will result in the initiation and growth of fatigue cracks; however, there have been no fretting-fatigue failures to date. Only a few incidents of fretting and wear have occurred with B\&W OTSG tubes, and the mechanism is not considered to be of serious concern for OTSGs.

Several PWRs have experienced reactor coolant system leakage due to cracked (and failed) steam generator primary manway stud bolts. The failure of these low alloy steel bolts has been attributed to accelerated stress corrosion cracking. The cracks occur when boric acid and/or lithium hydroxide leaks past the manway gasket and interacts with the studs' molybdenum disulfide lubricant. At Maine Yankee, five of twenty primary manway studs were found to be cracked. Six other studs had 
Table 4.7 Aging degradation concerns and mechanisms for the steam generator tubes

\begin{tabular}{|c|c|c|c|}
\hline Degradation Sites & Aging Concerns & Aging Mechanisms & References" \\
\hline $\begin{array}{l}\text { Primary side of steam } \\
\text { generator tubes }\end{array}$ & Crack initiation and growth & $\begin{array}{l}\text { Primary water stress } \\
\text { corrosion cracking; } \\
\text { Denting } \\
\end{array}$ & pp. 271-276 \\
\hline \multirow{3}{*}{$\begin{array}{l}\text { Secondary side of steam } \\
\text { generator tubes }\end{array}$} & Crack initiation and growth & Intergranular corrosion & pp. 276-279 \\
\hline & Leakage through tube walls & Pitting & pp. 279-281 \\
\hline & $\begin{array}{l}\text { Leakage through tube } \\
\text { walls; Reduction in fatigue } \\
\text { strength }\end{array}$ & Fretting & pp. $283-286$ \\
\hline U-bend regions of RSG tubes & Tube rupture & High-cycle fatigue & pp. 281-283 \\
\hline \multirow{2}{*}{$\begin{array}{l}\text { Secondary side of OTSG } \\
\text { tubes }\end{array}$} & Tube wall thinning & Erosion-corrosion & p. 287 \\
\hline & Through wall cracking & Corrosion fatigue & p. 287 \\
\hline
\end{tabular}

completely failed. At another facility, two bolts failed while being detensioned, and a third was found to have a crack extending through about $90 \%$ of its diameter.

High-cycle fatigue has caused tube ruptures in RSGs at two plants. Such ruptures are serious because of the challenge to safety systems and the release of radioisotopes from the RCPB. However, high-cycle fatigue does not appear to be a general problem for PWR steam generators.

Erosion-corrosion has been a minor problem for a few plants with OTSGs, but the tube-wall thinning has been localized and has not lead to tube rupture. Likewise, corrosion fatigue has occurred only at a few plants having OTSGs. Therefore, neither mechanism is considered to be of serious concern.

Wastage was a problem for RSGs of plants that used phosphate water chemistry control. This method is no longer in use at nuclear plants in the United States; thus, wastage is not currently an issue of concern. One other potential concern is corrosion or fatigue cracking of welds in the steam generator shell.

\subsubsection{Managing Aging Degradation}

Options for managing aging degradation of PWR steam generator tubes are summarized in Table 4.8. EPRI has funded the development of techniques for inservice inspection of steam generator tubing (Thompson and Elsley 1983).

Various techniques are available for reducing stresses on the interior (primary side) of steam generator tubes; these techniques, which include shot peening, retropeening, stress relieving by thermal treatment, and reducing the hot-leg temperature, may significantlydelay the onset of PWSCC. Plugging, sleeving, or replacing the affected tubes are the only effective repair methods. Lowenstein et al. (1991) have reviewed life assessment procedures for the steam generator tubes.

Control of secondary water chemistry is the first line of defense against aging degradation of steam generator tubing. Extending the life of steam generators involves stringent controls on impurities (primarily chloride, iron, and copper ions) and oxygen in the secondary-side water and preventing buildup of sludge. Loss of control of water chemistry can result in sig cant degradation in a short period of time. Condenser leakages, resin releases from condensate polishers, and the intro duction of chlorine-containing inorganics through makeup-water sources have been major contributors to the loss of water chemistry 
Table 4.8 Managing aging degradation of PWR steam generator tubes

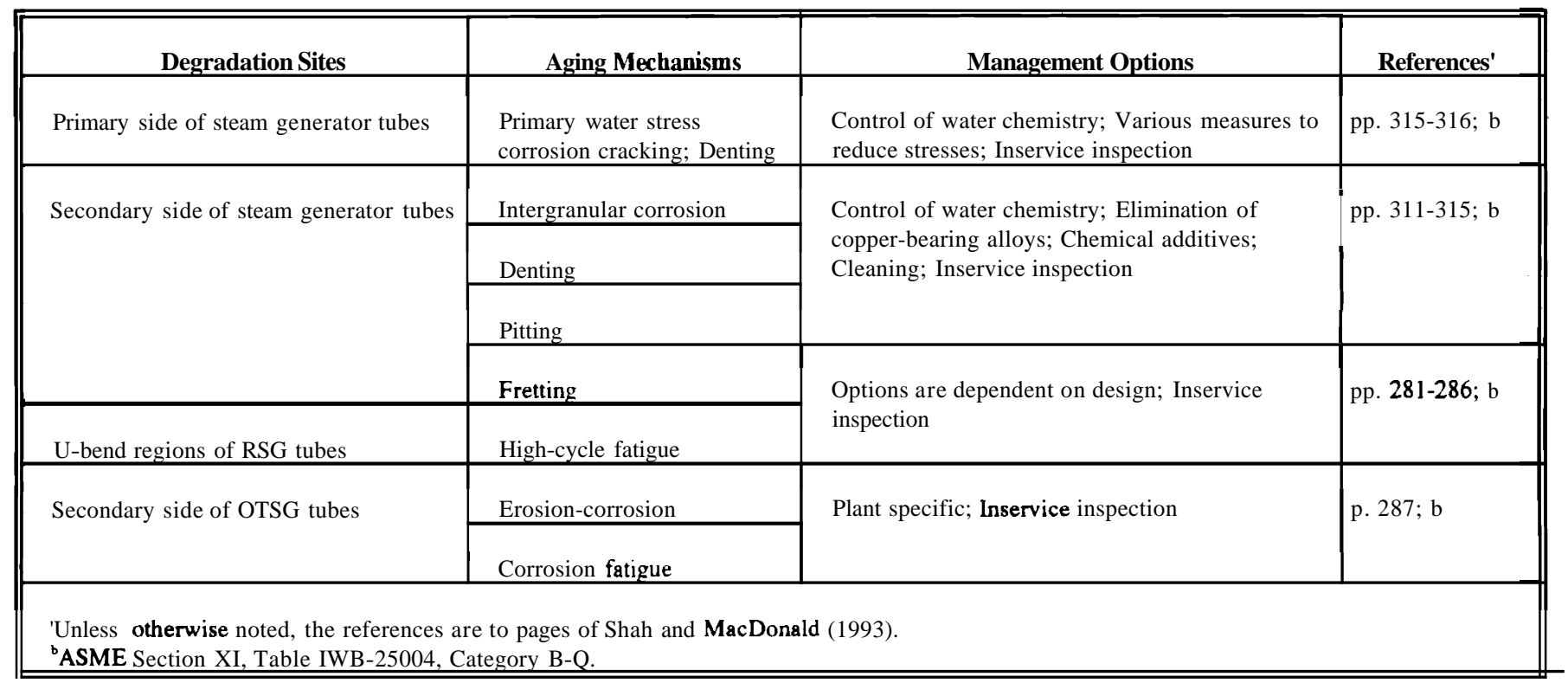

control. It has been demonstrated that certain chemical additives (e.g., boric acid and morpholine) will reduce IGA, stress corrosion cracking, and denting of tubes. Effects of these additives on other plant components are not well known. The guidelines established by EPRI (Wood 1990), for continuous monitoring and control of water chemistry, should be followed to reduce impurities in the secondary water.

Denting, fretting wear, and erosion-corrosion of the tubes are generally detectable during normal inservice inspection, before leakage occurs. Localized pitting and cracking (due to fretting-fatigue, stress corrosion, and some forms of intergranular attack) are more difficult to detect before leaks develop. Behravesh (1992) sets forth excellent guidelines and recommendations for inservice examinations of steam generators.

The root causes of fretting are dependent on specific design features of the steam generators; consequently, the most effective management options are also design dependent. In most cases, degradation appears to be limited to a specific region (for a specific design), and plugging of the affected tubes may be an effective remedy.

Occurrences of erosion-corrosion and corrosion fatigue have been limited to a few OTSGs, and management options appear to be plant specific.

Replacement of existing steam generators with those built of more corrosion resistant alloys (such as Alloy 690) is becoming a viable alternative to avoid increasing maintenance costs, outages, or deratings. Over 38 steam generators at thirteen nuclear plants have been replaced. Replacement times have progressively gotten shorter with improved methods and experience. Replacement ste m generators are expected to have a longer life because of improved designs and materials. The design improvements include elimination of crevices, lower residual stresses, and improved access for secondary-side lancing and chemical cleaning. The improved materials include thermally treated Alloy 600, mill-annealed Alloy 690, and thermally treated Alloy 690 for the tubes and femtic SS for the tube-support structures.

\subsection{Pressurizer (PWR)}

This section addresses aging degradation of the PWR pressurizer, including the associated surge and spray lines, nozzles, safeends, and spray heads. A simplified schematic of a pressurizer and the associated piping and valves is presented in Figure 4.11. The primary purpose of the pressurizer is to control the reactor coolant pressure and prevent steam generation in any other part of the PWR RCPB. The pressurizer is connected to the piping between the RPV outlet and the steam generator inlet 


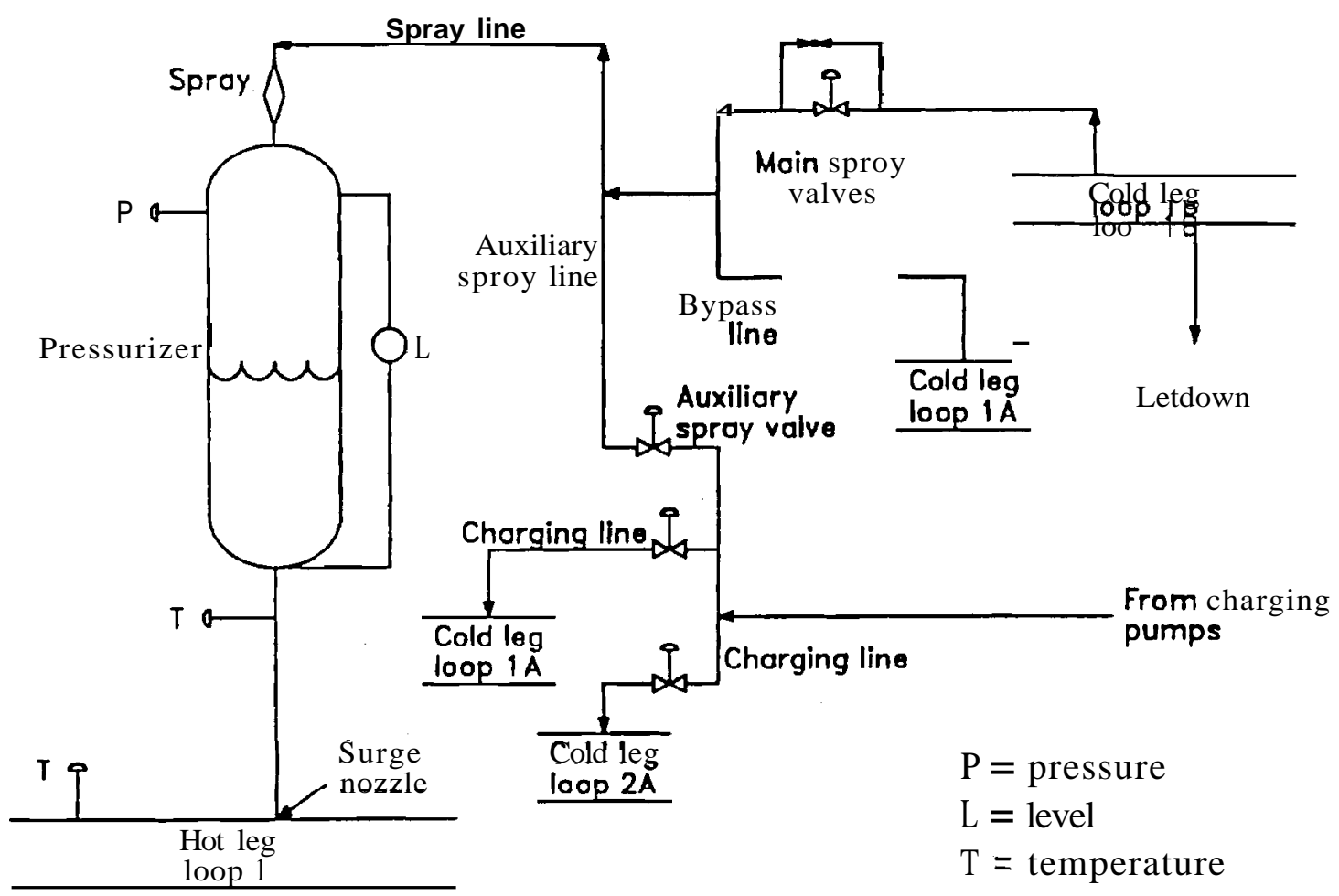

Figure 4.11 Simplified schematic of a pressurizer system (Siegel and Bakr 1989)

(hot leg). Pressure is controlled by altering the saturation temperature and pressure of the steam and water inside the pressurizer. Condensing the steam volume by spraying cooler water into it has the net effect of reducing system pressure. Increasing the steam temperature by using electric heaters to heat the water volume has the effect of increasing system pressure. A system of pressure relief valves is provided to prevent over pressurizing the reactor coolant system.

\subsubsection{Aging Degradation Concerns and Mechanisms}

The aging degradation concerns and mechanisms for the $\mathbf{P} \mathbf{W} \mathbf{R}$ pressurizers and associated components are summarized in Table 4.9.

The primary concerns regarding the pressurizer vessel are low-cycle fatigue due to plant operational, thermal, and pressure transients and high-cycle thermal fatigue caused by rapid temperature changes. The rapid changes are caused by the impingement of spray on the pressurizer walls, movement of the liquid at the steam-water interface, and water level changes caused by insurges, outsurges, and heater actuation. Cracking through the cladding can expose the base metal (low-alloy or carbon steel) to corrosion.

Surge and spray piping can be subjected to flow stratification which results in a severe circumferential temperature gradient leading to high thermal stresses. This causes significant fatigue damage and plastic deformation (Bulletin 88-11). The interface between the hot and cold layer also oscillates, leading to high cycle fatigue in surge and spray piping and nozzles.

Stress corrosion cracking and wear of pressurizer heater sheaths and sleeves has caused leaking of the primary coolant and loss or reduction of the spray pattern. Leaking of primary coolant can lead to stress corrosion cracking of manway bolts and corrosion of low-alloy steel in nearby components.

Leaking through the gaskets under the manhole covers subjects the bolts to a corrosive environment. 
Table 4.9 Aging degradation concerns and mechanisms for PWR pressurizers

\begin{tabular}{|c|c|c|c|c|}
\hline Components & Materials & Aging Concerns & Aging Mechanisms & References \\
\hline \multirow[t]{2}{*}{ Pressurizer vessel } & \multirow{2}{*}{$\begin{array}{l}\text { Low-alloy or carbon steel } \\
\text { with austenitic or } \\
\text { Alloy } 600 \text { cladding: } \\
\text { Cast SS }\end{array}$} & Loss of material & Boric acid corrosion & - \\
\hline & & $\begin{array}{l}\text { Crack initiation and } \\
\text { growth }\end{array}$ & $\begin{array}{l}\text { Fatigue; Stress corrosion } \\
\text { cracking }\end{array}$ & pp. $390-393$ \\
\hline $\begin{array}{l}\text { Surge and spray lines; } \\
\text { Nozzles }\end{array}$ & $\begin{array}{l}\text { SS; SS clad carbon- or } \\
\text { low-alloy steel: Cast SS }\end{array}$ & $\begin{array}{l}\text { Crack initiation and . } \\
\text { growth }\end{array}$ & $\begin{array}{l}\text { Fatigue, possibly } \\
\text { corrosion assisted }\end{array}$ & pp. $390-393$ \\
\hline Spray head & $\begin{array}{l}\text { Forged or cast SS; } \\
\text { Alloy } 600\end{array}$ & Loss of spray capability & $\begin{array}{l}\text { Erosion, Thermal } \\
\text { embrittlement, Fatigue }\end{array}$ & pp. $399-400$ \\
\hline $\begin{array}{l}\text { Heater sheaths; } \\
\text { Instrument } \\
\text { penetrations }\end{array}$ & SS; Alloy 600 & Leakage & $\begin{array}{l}\text { Intergranular stress } \\
\text { corrosion cracking, Boric } \\
\text { acid corrosion }\end{array}$ & $\begin{array}{l}\text { pp. 393- } \\
\text { 397: Notice } \\
90-10\end{array}$ \\
\hline Manway bolts & Low-alloy steel & Bolt breakage; Leakage & $\begin{array}{l}\text { Stress corrosion cracking; } \\
\text { Stress relaxation }\end{array}$ & pp. 397-399 \\
\hline
\end{tabular}

\subsubsection{Managing Aging Degradation}

The methods for managing aging degradation of PWR pressurizers are summarized in Table 4.10.

Analysis of fatigue life at critical locations should be performed, if adequate records have been maintained. Inservice inspection, using ultrasonic and visual techniques, is critical to ensuring that degradation of the pressurizer vessel will not limit the economic life of the plant.

Leakage of coolant through heater sheaths, instrument penetrations, or manway cover gaskets should be controlled as it can result in corrosion and SCC of other components of the pressurizer system.

Molybdenum disulfide lubricant should be avoided in any location where it could be exposed to steam. 
Table 4.10 Managing aging degradation of PWR pressurizers

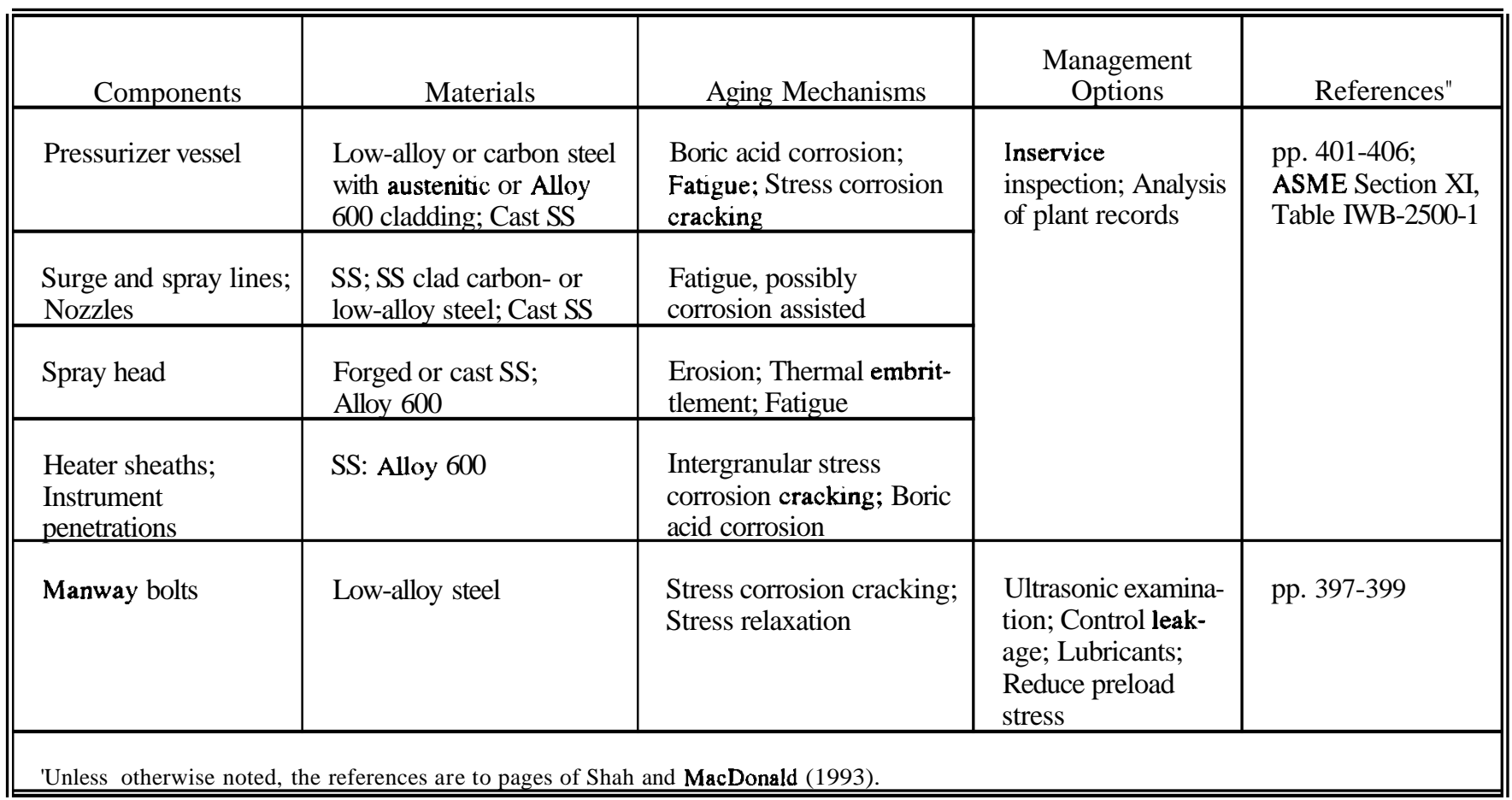

\subsection{References}

10 CFR 50.2. U.S. Code of Federal Regulations. 1992. "Definitions." U.S. Nuclear Regulatory Commission, Washington, D.C.

10 CFR 50.55a. U.S. Code of Federal Regulations. 1992. "Codes and Standards." U.S. Nuclear Regulatory Commission, Washington, D.C.

American Society of Mechanical Engineers (ASME). 1992. "Rules for Inservice Inspection of Nuclear Power Plant Components." In Section XI of the ASME Boiler and Pressure Vessel Code. American Society of Mechanical Engineers, New York.

Behravesh, M. 1992. PWR Stem Generator Examination Guidelines: Revision 3. EPRI NP-6201, Rev. 3, Electric Power Research Institute, Palo Alto, California..

Blahnik, D.E., D.A. Casada, J.L. Edson, D.L. Fineman, and W.E. Gunther. 1992. Insight Gained From Aging Research. NUREG/CR-5643, U.S. Nuclear Regulatory Commission, Washington, D.C.

Bogie, K.D., D. Alexander, and R. Kirk. 1992. "Aging of Cast Stainless Steel Components, " Intern. J. Pressure Vessel Piping, 50:161.

Chopra, O.K. 1994. Estimation of Fracture Toughness of Cast Stainless Steels During Thermal Aging in LWR Systems. NUREG/CR-4513, Rev. 1, ANL-93/22, prepared by Argonne National Laboratory for the U.S. Nuclear Regulatory Commission, Washington, D.C.

Chopra, O.K., and W.J. Shack. 1994. Assessment of Thermal Embrittlement of Cast Stainless Steels. NUREG/CR-6177, ANL-94/2, prepared by Argonne National Laboratory for the U.S. Nuclear Regulatory Commission, Washington, D.C. 
Cloud, R.L., and W.L. Sewer. 1987. "Pressurized Water Reactor Coolant Piping." In Residual Life Assessment of Major Light Warer Reactor Componenrs - Overview Volume I, eds. V.N. Shah and P.E. MacDonald. NUREG/CR-4731, EGG-2469, Volume 1, pp. 55-65, prepared by Robert L. Cloud Associates under contract to EG\&G Idaho, Inc. for the U.S. Nuclear Regulatory Commission, Washington, D.C.

Drahos, F.R., W.L. Sewer, and B.F. Beaudoin. 1989. "Light Water Reactor Coolant Pumps." In Residual Life Assessment of Major Lighr Water Reactor Components - Overview Volume 2, eds. V.N. Shah and P.E. MacDonald. NUREG/CR-4731 (EGG-2469), Volume 2, pp. 5-18, prepared by Robert L. Cloud Associates under contract to EG\&G Idaho for the U.S. Nuclear Regulatory Commission, Washington, D.C.

Egan, G.R. ,E.L. Capener, P.D. Hedgecock, R.C.Cipolla, and E.B. Clark. 1987. Inspection of Centrifugally Cast Stainless Steel Components in PWRs. EPRI-NP-5131, Electric Power Research Institute, Palo Alto, California.

Generic Letter 88-01. 1988. NRC Position on IGSCC in BWR Austenitic Stainless Steel Piping, NRC Generic Letter 88-01, and NRC Position on Intergranular Stress Corrosion Cracking (IGSCC) in BWR Austenitic Stainless Steel Piping, NRC Generic Letter 88-01, Supplement 1. U.S. Nuclear Regulatory Commission, Washington, D.C.

Generic Letter 88-05. 1988. Boric Acid Corrosion of Carbon Steel Reactor Pressure Boundary Components in PWR Plants, NRC Generic Letter 88-05, Supplement 1. U.S. Nuclear Regulatory Commission, Washington, D.C.

Guy, K.R. 1990. "Diagnostics Used on Power Generation Pumps." In Proceedings of the Symposium on Inservice Testing of Pumps and Valves, ed. F.A. Beranek. NUREG/CP-0111, U.S. Nuclear Regulatory Commission, Washington, D.C.

Hazelton, W.S., and W.H. Koo. 1988. Technical Report on Material Selection and Processing Guidelines for BWR Coolant Pressure Boundary Piping. NUREG-0313, Rev. 2, U.S. Nuclear Regulatory Commission, Washington, D.C.

Jaske, C.E., and V.N. Shah. 1990. Life Assessment Procedures for Major LWR Components. Volume 3: Cast Stainless Steel Components. NUREG/CR-5314 (EGG-2562), Volume 3, prepared by EG\&G Idaho for the U.S. Nuclear Regulatory Commission, Washington, D.C.

Jeong, P., and F. Ammirato. 1988. "Nondestructive Examination of Coolant Pump Welds-Ultrasonic Examination of Cast Stainless Steel Components." In 1988 ASME Pressure Vessel and Piping Conference, PVP 16. American Society of Mechanical Engineers, New York.

Lapides, M.E. 1991. Cast Austenitic Stainless Steel Sourcebook. EPRI TR-100034, Electric Power Research Institute, Palo Alto. California.

Light, G.M., N.R. Joshi, and S.N. Liu. 1986. "Stud Bolt Inspection Using Ultrasonic Cylindrically Guided Wave Technique.," In Improved Technology for Critical Bolting Applications, eds. E.A. Merrick and M. Prager, pp. 31-38. American Society of Mechanical Engineers, New York.

Liu, S.N. 1993. Application of the Cylindrically Guided Wave Technique (CGWT) for Bolt and Pump Shaft Inspection. EPRI TR-102703, Electric Power Research Institute, Palo Alto, California.

Lofaro, R., M. Subudhi, W. Gunter, W. Shier, R. Fullwood, and J.H. Taylor. 1989. Aging Study of Boiling Water Reactor Residual Heat Removal System. NUREG/CR-5268 (BNL-NUREG-52177), prepared by Brookhaven National Laboratory for the U.S. Nuclear Regulatory Commission, Washington, D.C.

Lowenstein, D.B., A.P.L. Turner, S.R. Ward, and J.A. Gorman. 1991. Life Assessment Procedures for Major LWR Components. Volume 4: Steam Generator Tubes. NUREG/CR-5314 (EGG-2562), Volume 4, prepared by EG\&G Idaho for the U.S. Nuclear Regulatory Commission, Washington, D.C.

Malhotra, V. 1987. "Pressurized Water Reactor Steam Generators." In Residual Life Assessment of Major Light Water Reactor Components - Overview Volume 1, eds. V.N. Shah and P.E. MacDonald. NUREG/CR-4731 (EGG-2469), Volume 1, 
pp. 66-78, prepared by Bechtel National under contract to EG\&G Idaho, Inc. for the U.S. Nuclear Regulatory Commission, Washington, D.C.

Shah, V.N., and P.E. MacDonald. eds. 1993. Aging and Life Extension of Major Light Water Reactor Components. Elsevier Publishing, New York.

Siegel, E.A., and M.H. Bakr. 1989. "Pressurized Water Reactor Surge and Spray Lines and Nozzles.!' In Residual Life Assessment of Major Light Water Reactor Components - Overview Volume 2, eds. V.N. Shah and P.E. MacDonald.

NUREG/CR-4731 (EGG-2469), Volume 2, pp. 46-62, prepared by Combustion Engineering under contract to EG\&G Idaho, Inc. for the U.S. Nuclear Regulatory Commission, Washington, D.C.

Thompson, R.B., and R.K. Elsley. 1983. A Prototype EMAT System for Inspection of Steam Generator Tubing. EPRI-NP2836, Electric Power Research Institute, Palo Alto, California.

U.S. Nuclear Regulatory Commission (NRC). 1983. Stress Corrosion Cracking in Large-Diameter Stainless Steel Recirculation System Piping at BWR Plants. NRC Bulletin No. 83-02, U.S. Nuclear Regulatory Commission, Washington, D.C.

U.S. Nuclear Regulatory Commission (NRC). 1988. Pressurizer Surge Line Thermal Stratification. NRC Bulletin No. 8811, U.S. Nuclear Regulatory Commission, Washington, D.C.

U.S. Nuclear Regulatory Commission (NRC). 1989. Stress Corrosion Cracking of High-Hardness Type 410 Stainless Steel Internal Preloaded Bolting in Anchor Darling Model S350W Swing Check Valves or Valves of Similar Design. NRC Bulletin No. 89-02, U.S. Nuclear Regulatory Commission, Washington, D.C.

U.S. Nuclear Regulatory Commission (NRC) Information Notice 86-108 and Supplements 1 (1987) and 2 (1987). 1986. Degradation of Reactor Coolant System Pressure Boundary Resulting From Boric Acid Corrosion. U.S. Nuclear Regulatory Commission, Washington, D.C.

U.S. Nuclear Regulatory Commission (NRC) Information Notice 90-10. 1990. Primary Water Stress Corrosion Cracking (PWSCC) of Inconel 600. U.S. Nuclear Regulatory Commission, Washington, D.C.

U.S. Nuclear Regulatory Commission (NRC) Information Notice 90-68 and Supplement 1 (1994). 1990. Stress Corrosion Cracking of Reactor Coolant Pump Bolts. U.S. Nuclear Regulatory Commission, Washington, D.C.

U.S. Nuclear Regulatory Commission (NRC) Information Notice 91-38. 1991. Thermal Stratification in Feedwater System Piping. U.S. Nuclear Regulatory Commission, Washington, D.C.

U.S. Nuclear Regulatory Commission (NRC) Information Notice 92-35. 1992. Higher than Predicted Erosion/Corrosion in Unsolable Reactor Coolant Pressure Boundary Piping Inside Containment at a Boiling Water Reactor. U.S. Nuclear Regulatory Commission, Washington, D.C.

U.S. Nuclear Regulatory Commission (NRC) Information Notice 92-50. 1992. Cracking of Valves in the Condensate Return Lines of a BWR Emergency Condenser System. U.S. Nuclear Regulatory Commission, Washington, D.C.

U.S. Nuclear Regulatory Commission (NRC) Information Notice 93-21. 1993. Summary of NRC Staff Observations Compiled During Engineering Audits or Inspections of Licensee Erosion/Corrosion Programs. U.S. Nuclear Regulatory Commission, Washington, D.C.

U.S. Nuclear Regulatory Commission (NRC) Information Notice 94-55. 1994. Problems With Copes-Vulcan Pressurizer Power-Operated Relief Valves. U.S. Nuclear Regulatory Commission, Washington, D.C.

Ware, A.G., V.N. Shah, and J.B. Buescher. 1989. "Boiling Water Reactor Feedwater and Main Steam Line Piping." In Residual Life Assessment of Major Light Water Reactor Components - Overview Volume 2, eds. V.N. Shah and P.E. 
MacDonald. NUREG/CR-4731 (EGG-2469), Volume 2, pp. 208-230, prepared by EG\&G Idaho, Inc. for the U.S. Nuclear Regulatory Commission, Washington, D.C.

Wood, C.J. 1990. PWR Primary Water Chemistry Guidelines: Revision 2. EPRI NP-7077, Electric Power Research Institute, Palo Alto, California..

Wu, P.C. 1989. Erosion/Corrosion-Induced Pipe Wall Thinning in U.S. Nuclear Power Plants. NUREG-1344, U.S. Nuclear Regulatory Commission, Washington. D.C. 


\section{Seismic Category I Structures}

Seismic Category I Structures house components, systems, and equipment that are relied on for safe operation and control of a nuclear power plant. The functions of Seismic Category I structures include ensuring the integrity of the RCPB, the capability to shut down the reactor and maintain it in a safe shutdown condition, and preventing or mitigating the consequences of accidents that could result in potential off-site exposure to radioactive materials. Other functions include the ability to withstand the effects of extreme environmental conditions and natural phenomena (hurricanes, floods, and seismic events) without loss of capability to protect equipment and systems.

Sections 5.1 and 5.2 address aging and aging management of PWR and BWR containments. The primary functions of containments are to house the NSSS, provide a barrier to atmospheric release of fission products that could be liberated from the primary coolant system during an accident; protect the reactor system from extreme environmental loads such as earthquakes, tornadoes, external explosions, and penetration by moving objects; and withstand design-basis earthquakes and pressures and temperatures associated with LOCA. Section 5.3 addresses the management of aging for other Seismic Category I structures.

\subsection{PWR Containment Structures}

This section addresses PWR containment structures for concrete (prestressed or reinforced) and freestanding steel designs. PWR containment structures provide a containment pressure boundary and leaktight barrier to radioactive release, and must be relatively large and strong to accommodate steam expansion from a primary coolant break.

The major components of the PWR containment structure comprise the following categories: the primary containment structure (which provides containment pressure boundary) constructed either of freestanding steel, prestressed concrete or reinforced concrete, with the concrete containments lined with steel to provide a leaktight barrier to radioactive release; basemats constructed of reinforced concrete that is lined with steel (which form the load bearing portion of the containment pressure boundary) for concrete containments and cylindrical steel containments with flat bottoms; and penetrations through the containments (which form part of the pressure boundary).

\subsubsection{Aging Degradation Concerns and Mechanisms}

Most PWR containments are constructed of prestressed concrete, a smaller number are of reinforced concrete, and a few are freestanding cylindrical steel structures housed in a reinforced concrete building (Figures 5.1, 5.2, and 5.3). These materials have been susceptible to internal and external environmental stressors, such as moisture, elevated temperature, freeze-thaw cycles, and cyclic loads (Shah and McDonald 1993, pp. 112-115). Aging degradation concerns considered to be significant for PWR reinforced concrete containment structures are 1) loss of strength and modulus due to elevated temperature, 2) scaling, cracking, and spalling due to freezethaw cycles, and 3) increase of porosity and permeability, cracking, and spalling due to leaching of calcium hydroxide, attack by aggressive chemicals, and reaction with aggregates. Aging degradation concerns considered to be significant for PWR steel containment structures and components are 1) cracking, spalling, loss of bond, and loss of material due to corrosion of embedded steel, prestressing tendons, structural steel, and liners and 2) reduction in design margin due to loss of prestress in prestressing tendons.

Aging degradation of penetration assemblies is common to both BWR and PWR containments. A significant number of manufacturers have produced cable connections and penetration assemblies, resulting in many different construction methods and aging concerns. Significant aging degradation concerns and their mechanisms are summarized in Table 5.1. 


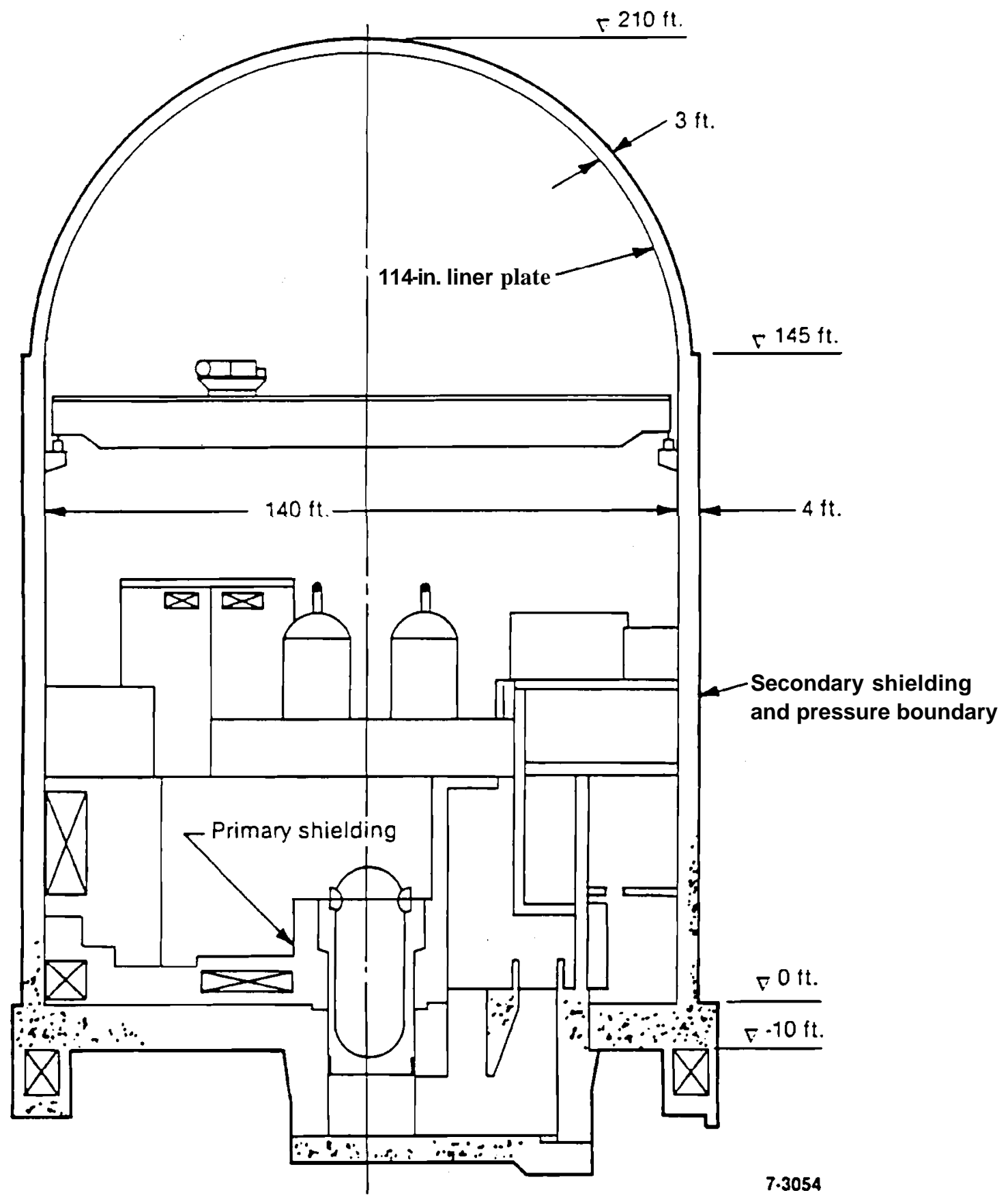

Figure 5.1 PWR prestressed concrete containment Type III @ aye 1987) 




Figure 5.2 PWR reinforced concrete containment @aye 1987) 


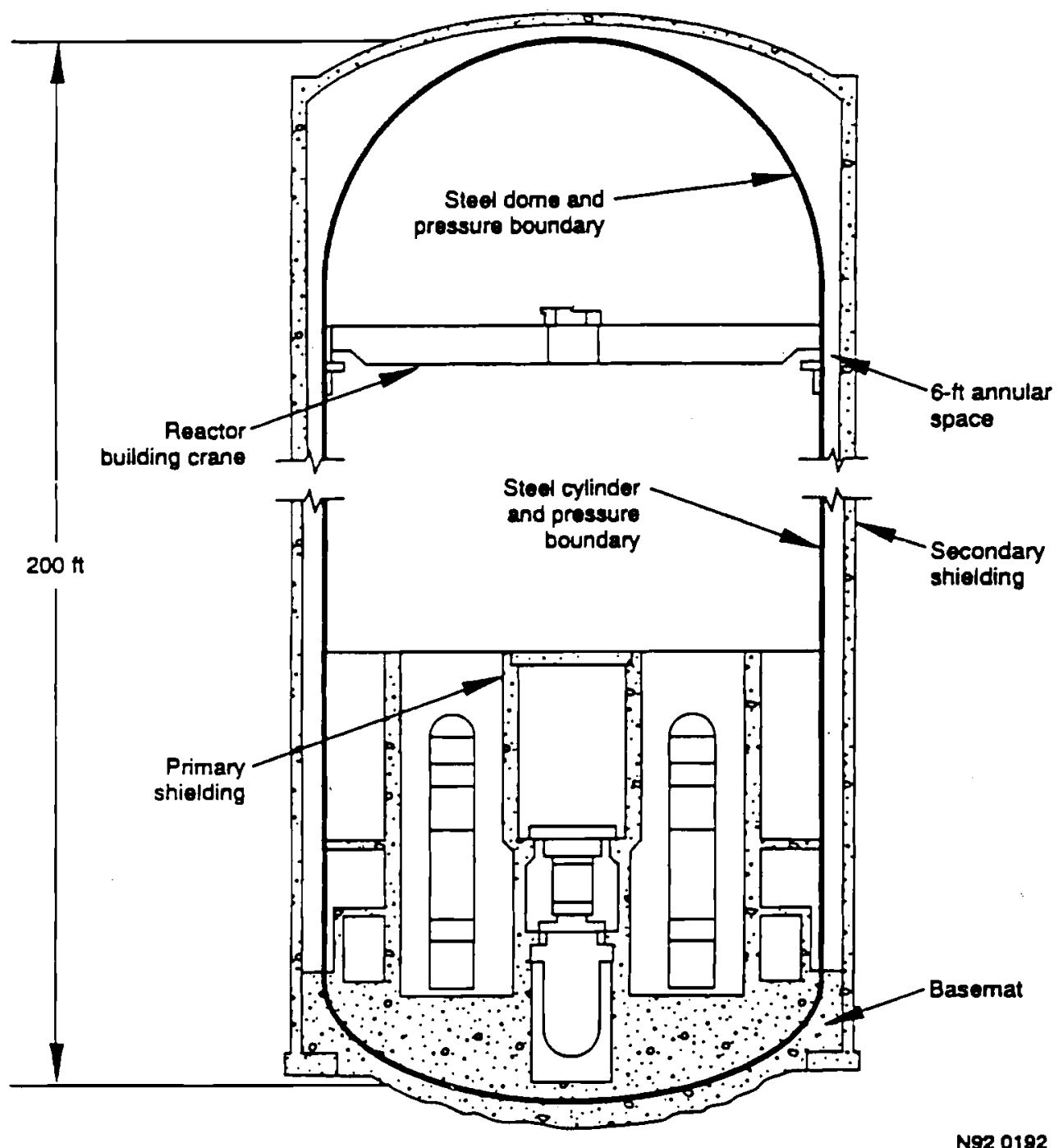

Figure 5.3 PWR cylindrical steel containment enclosed in a reinforced concrete reactor building.(Shah et al. 1994)

\subsubsection{Managing Aging Degradation}

A summary of options for managing significant aging degradation in PWR containment structures through inservice inspections, surveillance, monitoring, repair, and replacement is provided in Table 5.2. Containment structures and systems are subject to periodic leak rate testing, per 10 CFR 50 Appendix J, and to inspections of accessible exterior and interior surfaces for evidence of structural degradation before integrated leak-rate tests. For concrete structures, the inspection methods include visual, rebound, and core sampling, if required, and for the post-tensioning systems, a tendon surveillance program. Post-test inspections of concrete containments are required by technical specifications; additional requirements and guidance on preferred procedures are given in Regulatory Guide 1.35. Corrosion damage of the embedded portions of PWR metal containments is a major concern as is corrosion of both sides of the steel basemat liner or the outside surface of the liner on the below-grade wall of concrete containments. 
Table 5.1 Aging degradation concerns and mechanisms for PWR containment structures

\begin{tabular}{|c|c|c|c|c|}
\hline Components & Materials & Aging Concerns & Aging Mechanisms & $\begin{array}{c}\text { Reference } \\
\mathbf{s}^{*}\end{array}$ \\
\hline $\begin{array}{l}\text { All containments: } \\
\text { Mechanical and } \\
\text { electrical penetration } \\
\text { assemblies }\end{array}$ & $\begin{array}{l}\text { Various } \\
\text { (plant } \\
\text { specific) }\end{array}$ & $\begin{array}{l}\text { Loss of containment integrity; } \\
\text { Reduced electrical isolation } \\
\text { (shorting) }\end{array}$ & $\begin{array}{l}\text { Radiation; humidity; } \\
\text { temperature; chemical attack; } \\
\text { moisture }\end{array}$ & -- \\
\hline \multirow{3}{*}{$\begin{array}{l}\text { Concrete } \\
\text { containments: } \\
\text { Concrete dome; } \\
\text { Concrete } \\
\text { containment wall } \\
\text { above grade and } \\
\text { below grade }\end{array}$} & \multirow[t]{5}{*}{ Concrete } & $\begin{array}{l}\text { Loss of concrete strength and } \\
\text { modulus }\end{array}$ & $\begin{array}{l}\text { Loss of moisture due to } \\
\text { elevated temperature }\end{array}$ & p. 124 \\
\hline & & Scaling, cracking, and spalling & $\begin{array}{l}\text { Internal pressure due to } \\
\text { freeze-thaw }\end{array}$ & $\begin{array}{l}\text { PP. } \\
123-124\end{array}$ \\
\hline & & Increase of porosity and permeability & Leaching of calcium hydroxide & p. 123 \\
\hline \multirow{2}{*}{$\begin{array}{l}\text { Steel containments: } \\
\text { Concrete basemat }\end{array}$} & & $\begin{array}{l}\text { Increase of porosity and } \\
\text { permeability; Cracking and spalling }\end{array}$ & Aggressive chemical attack & $\begin{array}{l}\text { pp. } \\
121-123\end{array}$ \\
\hline & & Expansion and cracking & Reaction with aggregates & p. 125 \\
\hline $\begin{array}{l}\text { All containments: } \\
\text { Reinforcing steel }\end{array}$ & Carbon steel & $\begin{array}{l}\text { Cracking and spalling of concrete; } \\
\text { Loss strength }\end{array}$ & Corrosion of embedded steel & $\begin{array}{l}\text { pp. } \\
126-127\end{array}$ \\
\hline $\begin{array}{l}\text { Concrete } \\
\text { containments: } \\
\text { Containment and } \\
\text { basemat liner, } \\
\text { interior and exterior } \\
\text { surfaces; Liner } \\
\text { anchors above and } \\
\text { below grade }\end{array}$ & Carbon steel & Loss of material & $\begin{array}{l}\text { Corrosion of structural steel } \\
\text { and liner }\end{array}$ & $\begin{array}{l}\text { pp. } \\
128-129\end{array}$ \\
\hline \multirow{2}{*}{$\begin{array}{l}\text { Concrete } \\
\text { containments: } \\
\text { Prestressing tendons }\end{array}$} & \multirow[t]{2}{*}{ Carbon steel } & Loss of material & Corrosion of tendons & $\begin{array}{l}\text { PP. } \\
127-128\end{array}$ \\
\hline & & Reduction of design margin & Loss of prestress & p. 128 \\
\hline $\begin{array}{l}\text { Steel containments: } \\
\text { Containment, } \\
\text { interior and exterior } \\
\text { surfaces; Sand } \\
\text { pocket and } \\
\text { embedded shell } \\
\text { regions; Basemat } \\
\text { liner and anchors }\end{array}$ & Carbon steel & Loss of material & $\begin{array}{l}\text { Corrosion of structural steel } \\
\text { and liner }\end{array}$ & $\begin{array}{l}\text { pp. } \\
128-129\end{array}$ \\
\hline $\begin{array}{l}\text { Common components: } \\
\text { Penetration sleeves; } \\
\text { Personnel airlock; } \\
\text { Equipment hatches; } \\
\text { Dissimilar metal } \\
\text { welds }\end{array}$ & - & -- & -- & -- \\
\hline Penetration bellows & $\begin{array}{l}\text { Stainless } \\
\text { steel }\end{array}$ & -- & - & -- \\
\hline
\end{tabular}


Table 5.2 Managing aging degradation for PWR containment structures

\begin{tabular}{|c|c|c|c|c|}
\hline Components & Materials & Aging Mechanisms & Management Options & References' \\
\hline $\begin{array}{l}\text { All containments: } \\
\text { Mechanical and electrical } \\
\text { penetration assemblies }\end{array}$ & $\begin{array}{l}\text { Various } \\
\text { (plant } \\
\text { specific) }\end{array}$ & $\begin{array}{l}\text { Radiation; humidity; } \\
\text { temperature; chemical attack, } \\
\text { moisture }\end{array}$ & $\begin{array}{l}\text { Testing of penetration assemblies } \\
\text { (destructive and nondestructive) } \\
\text { under normal and severe accident } \\
\text { conditions }\end{array}$ & $\begin{array}{l}\text { Clauss (1989); } \\
\text { Jacobus (1990); } 10 \\
\text { CFR } 50 \text { Appendix J }\end{array}$ \\
\hline \multirow{5}{*}{$\begin{array}{l}\text { Concrete containments: } \\
\text { Concrete dome; Concrete } \\
\text { containment wall, above } \\
\text { grade and below grade } \\
\text { Steel containments: } \\
\text { Concrete basemat }\end{array}$} & \multirow[t]{4}{*}{ Concrete } & $\begin{array}{l}\text { Loss of moisture due to } \\
\text { elevated temperature }\end{array}$ & $\begin{array}{l}\text { Maintain required operating tem- } \\
\text { peratures or perform } \\
\text { plant-specific evaluation }\end{array}$ & ACI $349-90$ \\
\hline & & $\begin{array}{l}\text { Internal pressure due to } \\
\text { freeze-thaw }\end{array}$ & $\begin{array}{l}\text { Ensure concrete mix meets } \\
\text { requirements for weathering } \\
\text { conditions. }\end{array}$ & ASTM-C260-94 \\
\hline & & $\begin{array}{l}\text { Leaching of calcium } \\
\text { hydroxide }\end{array}$ & $\begin{array}{l}\text { Ensure concrete meets permeabil- } \\
\text { ity and crack control } \\
\text { requirements. }\end{array}$ & ACI $201.2 R-92$ \\
\hline & & Aggressive chemical attack & $\begin{array}{l}\text { Limit exposure to aggressive } \\
\text { ground water; Periodically } \\
\text { inspect accessible below-grade } \\
\text { surfaces; Perform plant-specific } \\
\text { evaluation of inaccessible } \\
\text { below-grade surfaces. }\end{array}$ & $\begin{array}{l}\text { ASME Section XI, } \\
\text { Subsection IWL, } \\
\text { examination category } \\
\text { L-A }\end{array}$ \\
\hline & & Reaction with aggregates & $\begin{array}{l}\text { Ensure aggregate meets } \\
\text { specifications. }\end{array}$ & $\begin{array}{l}\text { ASTM C227-90; } \\
\text { ASTM C295-85; } \\
\text { ACI 201.2R-92 }\end{array}$ \\
\hline $\begin{array}{l}\text { All containments: } \\
\text { Reinforcing steel }\end{array}$ & Carbon steel & Corrosion of embedded steel & $\begin{array}{l}\text { Ensure concrete exposed to } \\
\text { ground water meets specifica- } \\
\text { tions; Periodically inspect } \\
\text { accessible below-grade surfaces; } \\
\text { Perform plant-specific evaluation } \\
\text { of inaccessible below-grade } \\
\text { surfaces }\end{array}$ & $\begin{array}{l}\text { ASME Section III, } \\
\text { Subsectión CC }\end{array}$ \\
\hline \multirow[t]{2}{*}{$\begin{array}{l}\text { Concrete containments: } \\
\text { prestressing tendons }\end{array}$} & \multirow[t]{2}{*}{ Carbon steel } & Corrosion of tendons & $\begin{array}{l}\text { Visual examination; Evaluate } \\
\text { corrosion protection medium; } \\
\text { Repair or replace } \\
\end{array}$ & $\begin{array}{l}\text { Regulatory Guide } \\
1.35 ; \text { ASME Section } \\
\text { XI, Subsection IWL } \\
\end{array}$ \\
\hline & & Loss of prestress & $\begin{array}{l}\text { Inspection and load monitoring, } \\
\text { corrective action }\end{array}$ & Regulatory Guide 1.35 \\
\hline $\begin{array}{l}\text { Concrete containments: } \\
\text { Containment liner and } \\
\text { basemat liner, interior and } \\
\text { exterior surfaces; Liner } \\
\text { anchors above and below } \\
\text { grade }\end{array}$ & Carbon steel & Corrosion & $\begin{array}{l}\text { Ensure dissimilar metals not used } \\
\text { and aggressive ground water not } \\
\text { present; Visual inspection }\end{array}$ & pp. $135-136$ \\
\hline $\begin{array}{l}\text { Steel containments: } \\
\text { Containment shell, interior } \\
\text { and exterior surfaces; Sand } \\
\text { pocket and embedded shell } \\
\text { regions; Basemat liner and } \\
\text { anchors }\end{array}$ & \multirow[t]{2}{*}{ Carbon steel } & \multirow[t]{3}{*}{ Corrosion } & \multirow[t]{3}{*}{$\begin{array}{l}\text { Ensure dissimilar metals not } \\
\text { used; visual inspection }\end{array}$} & \multirow[t]{3}{*}{ pp. $139-140$} \\
\hline $\begin{array}{l}\text { Common components: } \\
\text { Penetration sleeves; } \\
\text { Personnel airlock, } \\
\text { Equipment hatches; Dis- } \\
\text { similar metal welds } \\
\end{array}$ & & & & \\
\hline Penetration bellows & $\begin{array}{l}\text { Stainless } \\
\text { steel }\end{array}$ & & & \\
\hline
\end{tabular}




\subsection{BWR Containment Structures}

This section addresses the management of BWR containment structures for the Mark I, II, and III reactor designs. BWR containment structures provide a containment pressure boundary and leaktight bamer to radioactive release, limit interior pressure in the containment in the event of a LOCA, and provide a continuing source of water for ECCS.

A typical steel Mark I containment, which is the predominant type of containment for BWRs in the United States is shown in Figure 5.4. A typical reinforced concrete Mark II containment, the second most predominant of U.S. BWRs, is shown in Figure 5.5. In addition to the two main types are a few steel Mark II and Mark III containments, reinforced concrete Mark I and Mark III containments, and prestressed Mark II containments; in general, components of these containments are affected by the same aging mechanisms that affect similar components in the two predominant types.

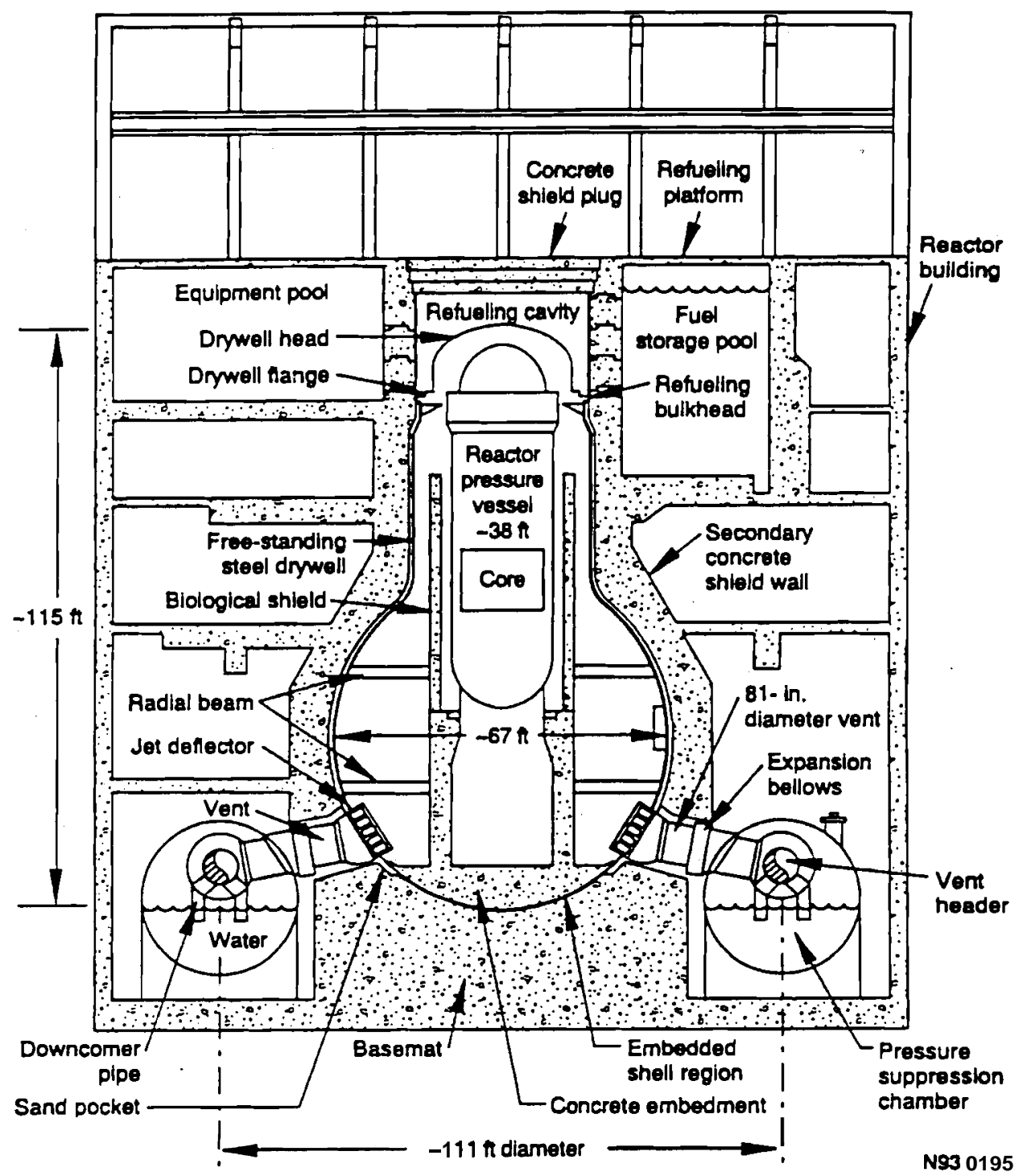

Figure 5.4 BWR Mark I Type steel containment (Shah et al. 1994) 


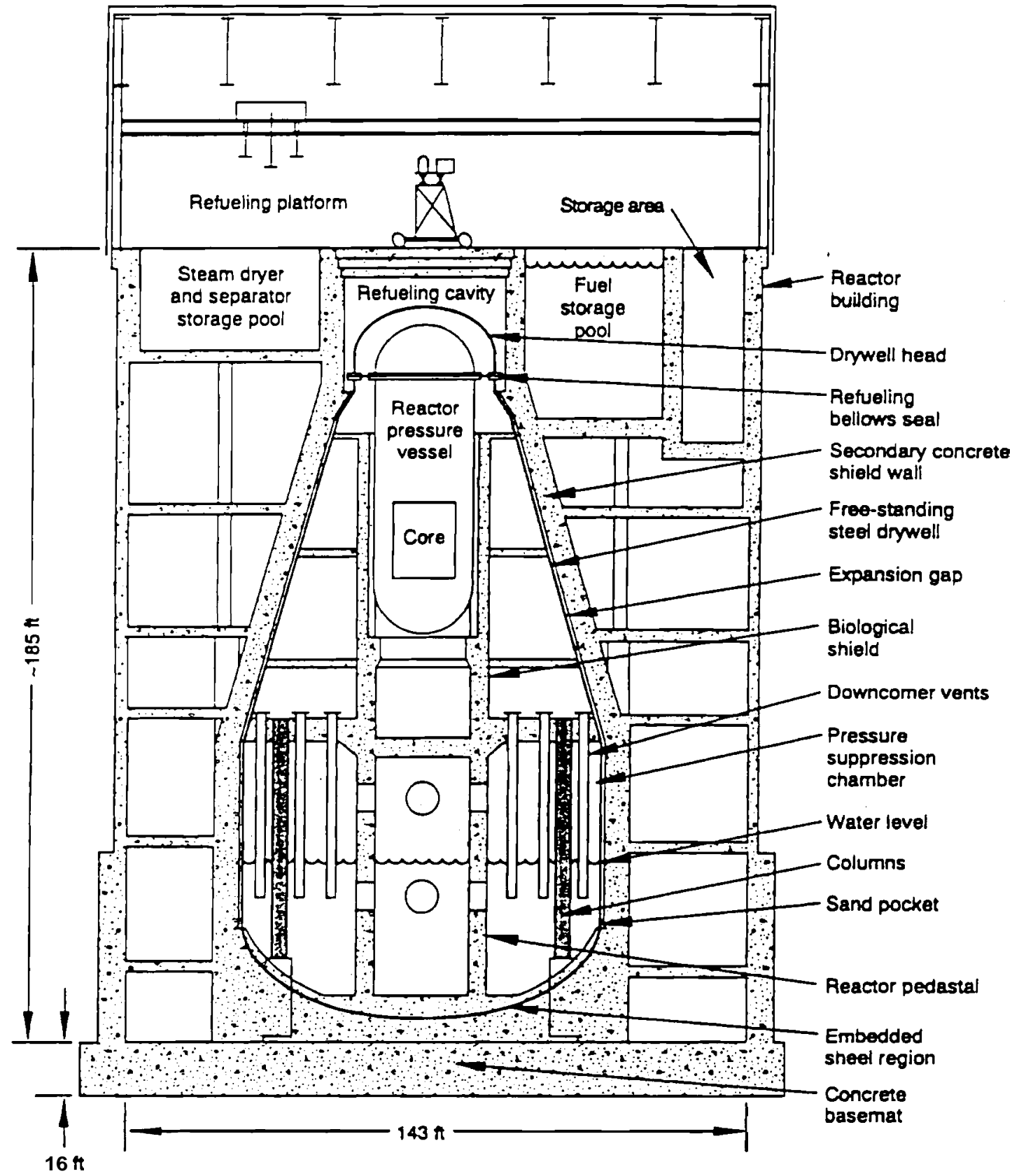

Figure 5.5 BWR Mark II Type reinforced concrete containment (Shah et al. 1989) 
A typical Mark III containment, which differs trom the Mark I and Mark II types by enclosing a much larger volume, is shown in Figure 5.6.

The ma or components of the BWR containment structures generally fall in one of the following categories: the primary containment structure (which provides containment pressure boundary) constructed either of freestanding steel, reinforced concrete, or prestressed concrete, with the concrete containments lined with steel to provide a leaktight barrier to radioactive release; basemats for Mark II and III containments constructed of reinforced concrete that is lined with steel (which form the load bearing portion of the containment pressure boundary); the drywell (which contains the RPV, recirculation system, and wetwell (or suppression chamber, torus-shaped in the Mark I design) and isolates the RPV from the reactor building while maintaining a vent path via downcomers to the wetwell); and the suppression pool (which limits interior pressure in the containment in the event of a LOCA and provides a continuing source of water for the ECCS).

The containment structure components described in this section do not include the reactor building structures and basemats of the two Mark I concrete containments, the diaphragm floors and support columns of Mark II containments, or the drywell and weir walls of Mark III containments; these are discussed in Section 5.3

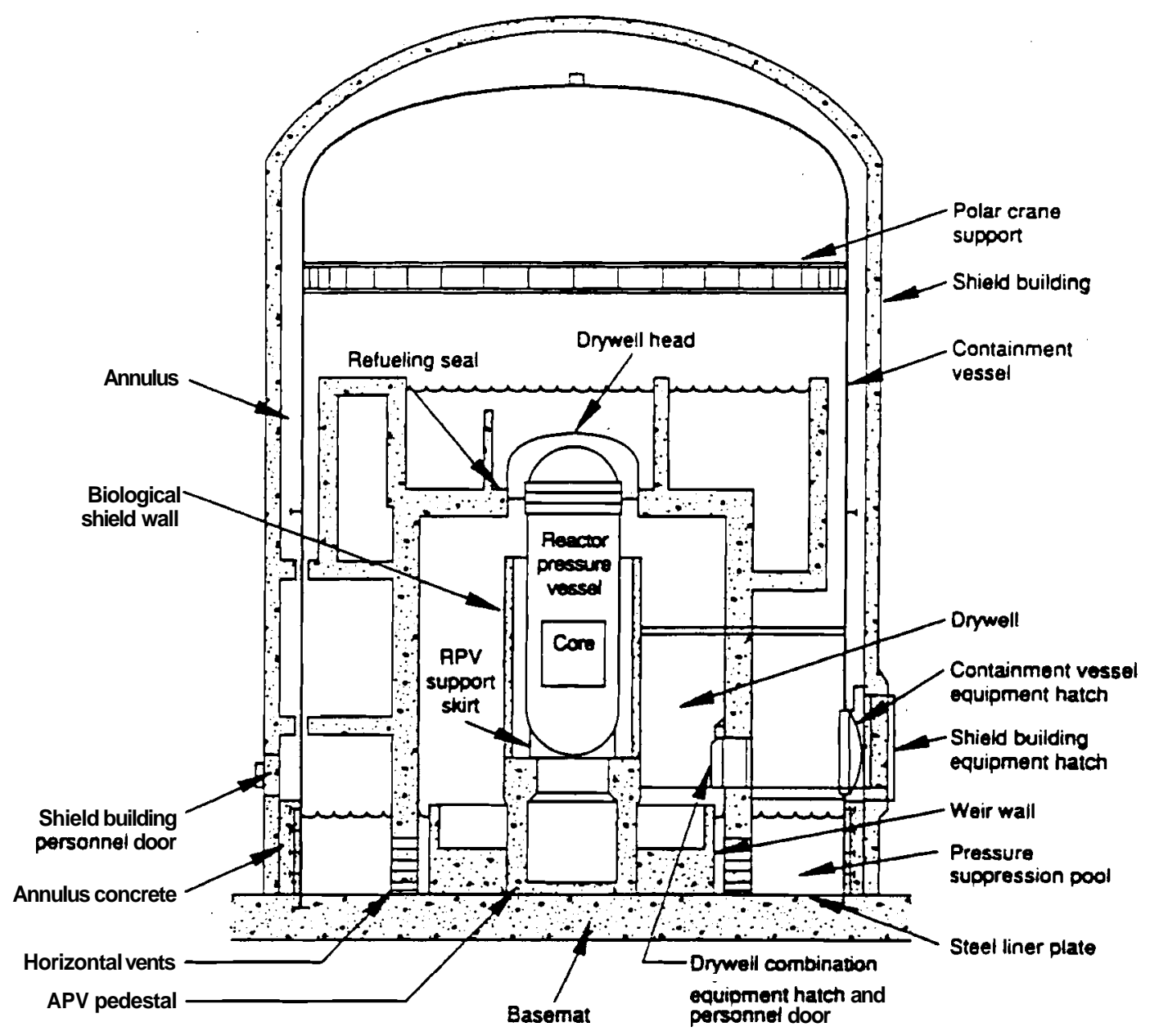

Figure 5.6 Mark III Type metal containment enclosed in a concrete shield building (Shah et al. 1994) 


\subsubsection{Aging Degradation Concerns and Mechanisms}

Containment structures for BWRs are fabricated from concrete (reinforced and prestressed), carbon steel, and austenitic SS. These materials have been susceptible to internal and external environmental stressors, such as moisture, elevated temperatures, freeze-thaw cycles, and cyclic loads (Shah and McDonald 1993, pp. 591-594). Aging degradation concerns considered to be significant for BWR reinforced concrete structures are 1) loss of strength and modulus due to elevated temperature, 2) scaling, cracking, and spalling due to freeze-thaw cycles, and 3) increase of porosity and permeability, cracking, and spalling due to leaching of calcium hydroxide, attack by aggressive chemicals, and reaction with aggregates. Aging degradation concerns considered to be significant for BWR steel structures and components are 1) cracking, spalling, loss of bond, and loss of material due to corrosion of embedded steel, prestressing tendons, structural steel, and liners; 2) lockup of contact surfaces due to wear of penetrations, bracings, and supports; 3) cumulative fatigue damage of vent headers and downcomers due to fatigue; and 4) reduction in design margin due to loss of prestress in prestressing tendons. These significant aging degradation concerns and their mechanisms are summarized in Table 5.3.

\subsubsection{Managing Aging Degradation}

A summary of options for managing significant aging degradation in BWR containment structures through inservice inspection (ISI), surveillance, monitoring, repair, and replacement is provided in Table 5.4. Containment structures and systems are subject to periodic leak-rate testing, per 10 CFR 50 Appendix J, and to inspections of accessible exterior and interior surfaces for evidence of structural degradation before integrated leak-rate tests. For concrete structures, the inspection methods include visual, rebound, and core sampling, if required, and for the post-tensioning systems, a tendon surveillance program. Post-test inspections of concrete containments are required by technical specifications; additional requirements and guidance on preferred procedures are given in Regulatory Guide 1.35. Corrosion damage of the embedded portions of BWR metal containments, the inaccessible outside surfaces of the Mark I and II drywells, and the ECCS piping that penetrates the torus are major concerns.

\subsection{Other Seismic Category I Structures}

Seismic Category I structures are multi-level structures consisting of reinforced concrete components (sometimes lined with steel plates to provide leak-tightness), masonry block walls, and structural steel and concrete-steel composite components that are supported on reinforced concrete foundations (basemats and/or piles). The Seismic Category I structures treated in this section comprise the following groups: 1) BWR reactor building, PWR shield building, and control room/building; 2) BWR reactor building with steel superstructure; 3) auxiliary building, diesel generator building, radwaste building, turbine building, switchgear room, auxiliary feedwater pump house, and utility/piping tunnel; 4) containment internal structures (excluding refueling canal); 5) fuel storage facility and refueling canal; 6) intake structure, cooling tower, and spray pond; 7) concrete tanks; 8) steel tanks; and 9) BWR unit vent stack. The review covers reinforced concrete (including concrete and reinforcing steel), reinforced concrete foundations (including concrete, reinforcing steel, and piles), masonry block walls, structural carbon steel used in steel-framed and composite structures (including metal siding, decking, and roofing), and stainless steel and carbon steel liners and anchors. This section does not include BWR and PWR containment structures, which are covered in Sections 5.1 and 5.2, nor tunnels and/or canals associated with the circulating water system, nor embankments and dams. 
Table 5.3 Aging degradation concerns and mechanisms for BWR containment structures

\begin{tabular}{|c|c|c|c|c|}
\hline Components & Materials & Aging Concerns & Aging Mechanisms & References' \\
\hline $\begin{array}{l}\text { All containments: } \\
\text { Mechanical and electrical penetration assemblies }\end{array}$ & $\begin{array}{l}\text { Various } \\
\text { (plant } \\
\text { specific) }\end{array}$ & $\begin{array}{l}\text { Loss of containment } \\
\text { integrity; Reduced } \\
\text { electrical isolation } \\
\text { (shorting) }\end{array}$ & $\begin{array}{l}\text { Radiation; Humidity; } \\
\text { Temperature; } \\
\text { Chemical attack; } \\
\text { Moisture } \\
\end{array}$ & \\
\hline \multirow{3}{*}{$\begin{array}{l}\text { Concrete containments: } \\
\text { Mark I drywell and torus; Mark II containment, con- } \\
\text { crete fill in the annulus, and basemat; Mark III } \\
\text { containment, containment wall above and below } \\
\text { grade, and basemat } \\
\text { Steel containments: } \\
\text { Mark III basemat and concrete fill in the annulus }\end{array}$} & \multirow[t]{5}{*}{ Concrete } & $\begin{array}{l}\text { Loss of concrete } \\
\text { strength and modulus }\end{array}$ & Elevated temperature & Kassir et al. 1993 \\
\hline & & $\begin{array}{l}\text { Increase of porosity } \\
\text { and permeability }\end{array}$ & $\begin{array}{l}\text { Leaching of calcium } \\
\text { hydroxide }\end{array}$ & p. 603 \\
\hline & & $\begin{array}{l}\text { Expansion and } \\
\text { cracking }\end{array}$ & $\begin{array}{l}\text { Reaction with } \\
\text { aggregates }\end{array}$ & p. 603 \\
\hline $\begin{array}{l}\text { Concrete containments: } \\
\text { Mark IIl containment and containment wall above } \\
\text { and below grade }\end{array}$ & & $\begin{array}{l}\text { Scaling, cracking, and } \\
\text { spalling }\end{array}$ & Freeze-thaw cycles & p. 603 \\
\hline $\begin{array}{l}\text { Concrete containments: } \\
\text { Mark I drywell and torus; Mark II basemat; Mark III } \\
\text { containment wall below grade } \\
\text { Steel containments: Mark III basemat } \\
\end{array}$ & & $\begin{array}{l}\text { Increase of porosity } \\
\text { and permeability, } \\
\text { cracking, and spalling }\end{array}$ & $\begin{array}{l}\text { Aggressive chemical } \\
\text { attack }\end{array}$ & p. 600 \\
\hline $\begin{array}{l}\text { Concrete containments: } \\
\text { Reinforcement steel in Mark I drywell and torus; } \\
\text { Mark II containment and basemat; Mark III } \\
\text { containment, containment wall below grade, and } \\
\text { basemat } \\
\text { Steel containments: } \\
\text { Mark III basemat reinforcing steel } \\
\end{array}$ & \multirow[t]{4}{*}{ Carbon steel } & $\begin{array}{l}\text { Cracking, spalling, } \\
\text { loss of bond, and loss } \\
\text { of material }\end{array}$ & $\begin{array}{l}\text { Corrosion of } \\
\text { embedded steel }\end{array}$ & pp. 603-694 \\
\hline $\begin{array}{l}\text { Steel containments: } \\
\text { Mark I ECCS suction header; Mark II suppression } \\
\text { chamber exterior surface; Mark I and Il drywell } \\
\text { exterior surface; Uncoated surfaces of containment } \\
\text { structures }\end{array}$ & & Loss of material & Corrosion & p. 594 \\
\hline $\begin{array}{l}\text { Common components: } \\
\text { Dissimilar metal welds; Mark I torus and Mark II } \\
\text { suppression chamber, interior surface at waterline; } \\
\text { Mark I and Il downcomers and bracing; Mark II } \\
\text { region shielded by diaphragm floor } \\
\text { Concrete containments: } \\
\text { Prestressed tendons } \\
\text { Steel containments: } \\
\text { Mark I and II drywell exterior shell with } \\
\text { compressible material; Mark I and Mark II drywell } \\
\text { support skirt, sand pocket region; Mark I, II, and III } \\
\text { embedded shell region }\end{array}$ & & Loss of material & Local corrosion & p. 598 \\
\hline $\begin{array}{l}\text { Concrete containments: } \\
\text { Mark I and II vent header, downcomers and bracing } \\
\text { Steel containments: } \\
\text { Mark } 1 \text { vent header, downcomers and bracing; Mark } \\
\text { Il unbraced downcomers }\end{array}$ & & $\begin{array}{l}\text { Crack initiation and } \\
\text { growth }\end{array}$ & Fatigue & pp. $600-601$ \\
\hline
\end{tabular}


Table 5.3 (Continued)

\begin{tabular}{|c|c|c|c|c|}
\hline Components & Materials & Aging Concerns & Aging Mechanisms & References' \\
\hline $\begin{array}{l}\text { Common components: } \\
\text { personnel airlock. equipment hatches. CRD hatch } \\
\text { Concrete containments: } \\
\text { Mark I and Il drywell head, downcomers and } \\
\text { bracing; Mark I vent system supports } \\
\text { Steel containments: } \\
\text { Mark } 1 \text { and II drywell head, downcomers and } \\
\text { bracing; Mark I vent system supports, torus suppon } \\
\text { columns/saddle and seismic restraints }\end{array}$ & $\begin{array}{l}\text { Carbon } \\
\text { steel, } \\
\text { Graphite }\end{array}$ & Lockup & Wear & p. 601 \\
\hline $\begin{array}{l}\text { Concrete containments: } \\
\text { Mark II containment concrete, prestress tendons }\end{array}$ & $\begin{array}{l}\text { Concrete, } \\
\text { Carbon steel }\end{array}$ & $\begin{array}{l}\text { Reduction of design } \\
\text { margin }\end{array}$ & Loss of prestress & p. 604 \\
\hline $\begin{array}{l}\text { Concrete containments: } \\
\text { Mark II and III suppression chamber interior SS } \\
\text { liners } \\
\text { Steel containments: } \\
\text { Mark III suppression chamber shell interior surface } \\
\text { or cladding surface }\end{array}$ & $\begin{array}{l}\text { Stainless } \\
\text { steel }\end{array}$ & $\begin{array}{l}\text { Crack initiation and } \\
\text { growth }\end{array}$ & $\begin{array}{l}\text { Stress corrosion } \\
\text { cracking }\end{array}$ & $\begin{array}{l}\text { Lee and } \\
\text { Szklarska- } \\
\text { Smulowska } 1988\end{array}$ \\
\hline
\end{tabular}

\subsubsection{Aging Degradation Concerns and Mechanisms}

The materials in Seismic Category I structures and components are susceptible to internal and external environmental stressors (moisture, aggressive chemicals, cyclic loads, etc.). Aging degradation concerns considered to be significant for Seismic Category I concrete structures are 1) scaling, cracking, and spalling due to freeze-thaw cycles; 2) increase of porosity and permeability, cracking, and spalling due to leaching of calcium hydroxide, attack by aggressive chemicals, and reaction with aggregates; 3) basemat cracking, distortion, and increase in component stress level due to settlement; 4) loss of material due to abrasion and cavitation; and 5) cracking of masonry walls due to restraint, shrinkage, creep, and aggressive environment. Aging degradation concerns considered to be significant for Seismic Category I steel structures and components are cracking, spalling, loss of bond, and loss of material due to corrosion of embedded steel, structural steel, and liners. The si cant aging concerns and the mechanisms that degrade components of Seismic Category I structures are summarized in Table 5.5.

\subsubsection{Managing Aging Degradation}

The options for managing significant aging degradation in Seismic Category I structures through inservice inspections, surveillance, monitoring, repair, and replacement are summarized in Table 5.6. A primary requirement for aging management is to mitigate the consequences of LOCAs and potential off-site release of radioactive materials.

Seismic Category I structures are subject to inspections of accessible exterior surfaces for evidence of structural degradation. Corrosion damage of the embedded steel reinforcements and structural steel and liners is a major concern as is loss of strength and cracking o masonry walls in proximity to, or having attachments from, safety-related piping or equipment. 
Table 5.4 Managing aging degradation for BWR containment structures

\begin{tabular}{|c|c|c|c|c|}
\hline Components & Materials & Aging Mechanisms & Management Options & References" \\
\hline $\begin{array}{l}\text { All containments: } \\
\text { Mechanical and electrical penetration } \\
\text { assemblies }\end{array}$ & $\begin{array}{l}\text { Vnrious } \\
\text { (plant } \\
\text { specific) }\end{array}$ & $\begin{array}{l}\text { Radiation: Humidity: } \\
\text { Temperature: } \\
\text { Chemicnl attack: } \\
\text { Moisture }\end{array}$ & $\begin{array}{l}\text { Testing of penetration assemblies } \\
\text { (destructive and nondestructive under } \\
\text { normal and severe accident conditions }\end{array}$ & $\begin{array}{l}\text { Claws (1989); } \\
\text { Jacobw (1990) } \\
10 \text { CFR 50 } \\
\text { Appendix J } \\
\end{array}$ \\
\hline \multirow{3}{*}{$\begin{array}{l}\text { Concrete containments: } \\
\text { Mnrk I drywell and torus: Mnrk II contain- } \\
\text { ment, concrete fill in the annulus, nnd } \\
\text { bnsemnt; Mnrk III containment. containment } \\
\text { wnll above and below grade, and basemat } \\
\text { Steel containments: } \\
\text { Mark III bnsemnt and concrete fill in the } \\
\text { annulus }\end{array}$} & \multirow[t]{5}{*}{ Concrete } & Elevated temperature & $\begin{array}{l}\text { Maintain required operating tem- } \\
\text { peratures or perform plant-specific } \\
\text { evaluation. }\end{array}$ & ACl 349-90 \\
\hline & & $\begin{array}{l}\text { Leaching of calcium } \\
\text { hydroxide }\end{array}$ & $\begin{array}{l}\text { Ensure concrete meets permeability } \\
\text { and crnck control requirements. }\end{array}$ & $\mathrm{ACl} 201.2 \mathrm{R}-92$ \\
\hline & & $\begin{array}{l}\text { Reaction with } \\
\text { nggregntes }\end{array}$ & Ensure nggregnte meets specifications. & $\begin{array}{l}\text { ASTM C227-90, } \\
\text { ASTM C295-85, } \\
\text { ACI 201.2R-92 }\end{array}$ \\
\hline $\begin{array}{l}\text { Concrete contninments: } \\
\text { Mnrk III containment and containment wall } \\
\text { nbove and below grnde }\end{array}$ & & Freeze-thaw cycles & $\begin{array}{l}\text { Ensure concrete mix meets require- } \\
\text { ments for weathering conditions. }\end{array}$ & ASTM-C260-94 \\
\hline $\begin{array}{l}\text { Concrete contninments: } \\
\text { Mnrk I drywell and torus; Mnrk Il basemat; } \\
\text { Mnrk IIl containment wall below grade } \\
\text { Steel containments: Mark III bnsemnt }\end{array}$ & & $\begin{array}{l}\text { Aggressive chemical } \\
\text { attack }\end{array}$ & $\begin{array}{l}\text { Limit exposure of above-ground sur- } \\
\text { faces to aggressive ground water to in- } \\
\text { termittent periods. Periodically inspect } \\
\text { accessible below-grade surfaces. } \\
\text { Perform plant-specific evaluation of } \\
\text { innccessible below-grade surfnces. }\end{array}$ & ACI $318-92$ \\
\hline $\begin{array}{l}\text { Concrete contninments: } \\
\text { Reinforcement steel in Mnrk I drywell and } \\
\text { torus; Mark II containment and basemat: } \\
\text { Mnrk III contninment, containment wall } \\
\text { below grnde. and bnsemnt } \\
\text { Steel containments: } \\
\text { Mnrk IIl bnsemnt reinforcing steel }\end{array}$ & \multirow[t]{4}{*}{ Carbon steel } & $\begin{array}{l}\text { Corrosion of } \\
\text { embedded steel }\end{array}$ & $\begin{array}{l}\text { Ensure concrete of above-ground sur- } \\
\text { faces exposed to ground water meets } \\
\text { specifications. Periodically inspect } \\
\text { accessible below-grade surfaces. } \\
\text { Perform plant-specific evaluation of } \\
\text { inaccessible below-grade surfnces. }\end{array}$ & $\begin{array}{l}\text { ASME Section III. } \\
\text { Division } 2\end{array}$ \\
\hline $\begin{array}{l}\text { Steel contninments: } \\
\text { Mark I ECCS suction header: Mnrk II sup- } \\
\text { pression chnmber exterior surfnce: Mnrk I } \\
\text { nnd Il drywell exterior surface: Uncoated } \\
\text { surfaces of containment structures }\end{array}$ & & Corrosion & $\begin{array}{l}\text { VT-I inspection of surfaces likely to } \\
\text { experience accelernted corrosion, } \\
\text { VT-3 examination of containment } \\
\text { shell welds, and VT- } 3 \text { examination of } \\
\text { accessible containment pressure } \\
\text { boundary in conjunction with } 10 \text { CFR } \\
50 \text { Appendix J Type A leak rnte teat. }\end{array}$ & $\begin{array}{l}\text { ASME Section XI, } \\
\text { Subsection IWE exam } \\
\text { categories E-A. E-P, } \\
\text { and E-C, } \\
\text { respectively; } 10 \text { CFR } \\
50 \text { Appendix J }\end{array}$ \\
\hline $\begin{array}{l}\text { Common components: } \\
\text { Dissimilar metal welds; Mark I torus and } \\
\text { Mnrk II suppression chamber, interior } \\
\text { surface at waterline; Mnrk I and Il down- } \\
\text { comers and bracing; Mark II region shielded } \\
\text { by dinphrngm floor } \\
\text { Concrete containments; } \\
\text { Prestressed tendons } \\
\text { Steel contninments: } \\
\text { Mark I and Il drywell exterior shell with } \\
\text { compressible material; Mnrk I and Mark II } \\
\text { drywell support skirt, snnd pocket region; } \\
\text { Mnrk I. II. and IIl embedded shell region } \\
\end{array}$ & & Local corrosion & $\begin{array}{l}\text { Periodic VT-I inspection of surfaces } \\
\text { likely to experience accelerated } \\
\text { corrosion; A plmt-specific program is } \\
\text { required for inaccessible and/or } \\
\text { embedded carbon steel containment } \\
\text { components. Examine tendon anchor- } \\
\text { age hardware. evaluate. corrosion } \\
\text { protection medium. }\end{array}$ & $\begin{array}{l}\text { ASME Section XI. } \\
\text { Subsection IWE } \\
\text { examination category } \\
\text { E-C } \\
\text { Regulatory Guide } \\
1.35\end{array}$ \\
\hline $\begin{array}{l}\text { Concrete contninments: } \\
\text { Mnrk I and II vent header, downcomers and } \\
\text { brncing } \\
\text { Steel contninments: } \\
\text { Mark I vent header. downcomers and } \\
\text { brncing: Mnrk } 11 \text { unbrnced downcomers }\end{array}$ & & Fatigue & $\begin{array}{l}\text { Perform fatigue re-analysis; consider } \\
\text { effects of environmentally assisted } \\
\text { fatigue crack initiation and growth. }\end{array}$ & $\begin{array}{l}\text { ASME Section XI. } \\
\text { Subsection IWE }\end{array}$ \\
\hline
\end{tabular}


Table 5.4 (Continued)

\begin{tabular}{|c|c|c|c|c|}
\hline Components & Materials & Aging Mechanisms & Management Options & References' \\
\hline $\begin{array}{l}\text { Common components: } \\
\text { personnel airlock, equipment hatches, CRD } \\
\text { hatch } \\
\text { Concrete containments: } \\
\text { Mark I nnd Il drywell head, downcomers nnd } \\
\text { brncing: Mnrk I vent system supports } \\
\text { Steel contninments: } \\
\text { Mark I nnd Il drywell bend, downcomers nnd } \\
\text { bmcing; Mnrk I vent system supports, torus } \\
\text { support columns/saddle nnd seismic restraints }\end{array}$ & $\begin{array}{l}\text { Cnrbon } \\
\text { steel. } \\
\text { Graphite }\end{array}$ & Wenr & $\begin{array}{l}\text { Examine airlock, equipment hutches. } \\
\text { CRD hatch nnd drywell bead every } \\
\text { inspection interval ( } 10 \text { yrs): VT-I } \\
\text { examination of bolted connections. } \\
\text { VT- } 3 \text { examination of seals nnd } \\
\text { penetrations, and VT- } 3 \text { exnminntion of } \\
\text { bracings, restraints, nnd supports. }\end{array}$ & $\begin{array}{l}\text { ASME Section XI, } \\
\text { Subsection IWE and } \\
\text { IWF }\end{array}$ \\
\hline $\begin{array}{l}\text { Concrete containments: } \\
\text { Mark II containment concrete. prestress } \\
\text { tendons }\end{array}$ & $\begin{array}{l}\text { Concrete. } \\
\text { Cnrbon steel }\end{array}$ & Loss of prestress & $\begin{array}{l}\text { periodic monitoring of prestressing } \\
\text { losses in accordance with tendon } \\
\text { lift-off test }\end{array}$ & $\begin{array}{l}\text { Regulatory Guide } \\
1.35\end{array}$ \\
\hline $\begin{array}{l}\text { Concrete containments: } \\
\text { Mnrk II and IIl suppression chnmber interior } \\
\text { SS liners } \\
\text { Steel contaınments: } \\
\text { Mnrk III suppression chnmber shell interıor } \\
\text { surface or cladding surfnce }\end{array}$ & $\begin{array}{l}\text { Stainless } \\
\text { steel }\end{array}$ & $\begin{array}{l}\text { Stress corrosion } \\
\text { cracking }\end{array}$ & $\begin{array}{l}\text { Detection of liner leakage vin } \\
\text { 10CFR50 Appendix J Type A leak mte } \\
\text { test: repair, replacement, nnd retest }\end{array}$ & $\begin{array}{l}10 \text { CFR } 50 \text { Appendix } \\
\text { J, ASME Section XI. } \\
\text { Subsection IWE }\end{array}$ \\
\hline
\end{tabular}


Table 5.5 Aging degradation concerns and mechanisms for other Seismic Category I structures

\begin{tabular}{|c|c|c|c|c|}
\hline Components & Materials' & Aging Concerns & Aging Mechanisms & References \\
\hline \multirow{7}{*}{$\begin{array}{l}\text { GROUP } 1 \\
\text { BWR reactor building, } \\
\text { PWR shield building, Control } \\
\text { room/building } \\
\text { GROUP } 2 \\
\text { BWR reactor building with steel } \\
\text { superstructure } \\
\text { GROUP } 3 \\
\text { Auxiliary building, Diesel generator } \\
\text { building, Radwaste building, Turbine } \\
\text { building Switchgear room, Auxiliary } \\
\text { feedwater pump house, Utility/piping } \\
\text { tunnel } \\
\text { GROUP } 4 \\
\text { Containment internal structures } \\
\text { (excluding refueling canal) } \\
\text { GROUP } 5 \\
\text { Fuel storage facility, Refueling canal } \\
\text { GROUP } 6 \\
\text { Intake structure, Cooling tower, Spray } \\
\text { pond } \\
\text { GROUP } 7 \\
\text { Concrete tanks } \\
\text { GROUP } 9 \\
\text { BWR unit vent stack } \\
\text { GROUP } 8 \\
\text { Steel tanks } \\
\end{array}$} & \multirow{7}{*}{$\begin{array}{l}\text { Concrete: }{ }^{b} \text { F, ExA. } \\
\text { InW, InS, interior and } \\
\text { exterior concrete, } \\
\text { concrete above and } \\
\text { below grade; masonry } \\
\text { block walls }\end{array}$} & $\begin{array}{l}\text { Scaling, cracking, } \\
\text { and spalling }\end{array}$ & $\begin{array}{l}\text { Internal pressure } \\
\text { due to freeze-thaw } \\
\text { cycles }\end{array}$ & Stump et al. 1987 \\
\hline & & $\begin{array}{l}\text { Increase of } \\
\text { porosity and } \\
\text { permeability }\end{array}$ & $\begin{array}{l}\text { Leaching of calcium } \\
\text { hydroxide }\end{array}$ & Troxell et al. 1968 \\
\hline & & $\begin{array}{l}\text { Increase of } \\
\text { porosity and } \\
\text { permeability, } \\
\text { cracking, and } \\
\text { spalling }\end{array}$ & $\begin{array}{l}\text { Aggressive chemical } \\
\text { attack }\end{array}$ & Mehta 1986 \\
\hline & & $\begin{array}{l}\text { Expansion and } \\
\text { cracking of } \\
\text { concrete }\end{array}$ & $\begin{array}{l}\text { Reaction with } \\
\text { aggregates }\end{array}$ & Mehta 1986 \\
\hline & & $\begin{array}{l}\text { Cracking of } \\
\text { masonry walls }\end{array}$ & $\begin{array}{l}\text { Restraint; } \\
\text { Shrinkage; Creep; } \\
\text { Aggressive } \\
\text { environment }\end{array}$ & $\begin{array}{l}\text { IE Bulletin } 80-11 \\
\text { Information Notice } \\
87-67\end{array}$ \\
\hline & & $\begin{array}{l}\text { Basemat cracking; } \\
\text { Distortion; Increase } \\
\text { in component stress } \\
\text { level }\end{array}$ & Settlement & Bowles 1988 \\
\hline & & $\begin{array}{l}\text { Cracking, spelling, } \\
\text { loss of bond, and } \\
\text { loss of material of } \\
\text { steel }\end{array}$ & $\begin{array}{l}\text { Corrosion of } \\
\text { embedded steel }\end{array}$ & ACI 222R-85 \\
\hline $\begin{array}{l}\text { GROUP } 6 \\
\text { Intake structure, Cooling tower, Spray } \\
\text { pond }\end{array}$ & $\begin{array}{l}\text { Concrete: F, ExA, ExB, } \\
\& \text { InS }\end{array}$ & Loss of Material & $\begin{array}{l}\text { Abrasion and } \\
\text { cavitation }\end{array}$ & ACI 210R-92 \\
\hline $\begin{array}{l}\text { GROUP } 5 \\
\text { Fuel storage facility, Refueling canal }\end{array}$ & Stainless steel liner & Loss of material & $\begin{array}{l}\text { Corrosion of stain- } \\
\text { less steel liner }\end{array}$ & $\begin{array}{l}\text { EPRI NP-3765; } \\
\text { EPRI NP-4561 }\end{array}$ \\
\hline $\begin{array}{l}\text { GROUP } 6 \\
\text { Intake structure, Cooling tower, Spray } \\
\text { pond }\end{array}$ & Structural steel & Loss of material & $\begin{array}{l}\text { Corrosion of } \\
\text { structural steel }\end{array}$ & ANSI/AISC N690 \\
\hline \multicolumn{5}{|c|}{$\begin{array}{l}\text { 'Component types are as follows: Concrete foundation including concrete piles (F), exterior concrete above grade (ExA), exterior concrete } \\
\text { below grade (ExB), interior concrete walls including columns (InW), interior concrete slabs including beams (InS), and interior concrete } \\
\text { structures above grade (InA). Structural steel components include columns, baseplates, beams, girders, trusses, and bracings; and jet } \\
\text { impingement barriers for Groups 1-4. } \\
\text { 'W With embedded reinforcing carbon steel. }\end{array}$} \\
\hline
\end{tabular}


Table 5.6 Managing aging degradation for other Seismic Category I structures

\begin{tabular}{|c|c|c|c|c|}
\hline Components & Materials' & Aging Mechanisms & Management Options & References \\
\hline \multirow{3}{*}{$\begin{array}{l}\text { GROUP } 1 \\
\text { BWR renctor building. PWR shield } \\
\text { building. Control roomlbuildmg } \\
\text { GROUP } 2 \\
\text { BWR reactor building with steel } \\
\text { superstructure } \\
\text { GROUP } 3 \\
\text { Auxilinry building. Diesel generntor } \\
\text { building. Radwaste building. Turbine } \\
\text { building. Switchgear room. Auxiliary } \\
\text { feedwater pump house. Utility/piping } \\
\text { tunnel } \\
\text { GROUP } 4 \\
\text { Containment internal structures (excluding } \\
\text { refueling canal) }\end{array}$} & \multirow{6}{*}{$\begin{array}{l}\text { Concrete: }{ }^{b} \text { F. ExA. } \ln W \text {, } \\
\text { InS. interior nnd exterior } \\
\text { concrete. concrete above } \\
\text { nnd below grade; masonry } \\
\text { block walls }\end{array}$} & $\begin{array}{l}\text { Internal pressure } \\
\text { due to freeze-thaw } \\
\text { cycles }\end{array}$ & $\begin{array}{l}\text { Ensure concrete mix meets } \\
\text { requirements for weathering } \\
\text { conditions }\end{array}$ & ACI $349-90$ \\
\hline & & $\begin{array}{l}\text { Leaching of } \\
\text { calcium hydroxide }\end{array}$ & $\begin{array}{l}\text { Ensure concrete meets } \\
\text { permeability and crack control } \\
\text { requirements. }\end{array}$ & ACI 201.2R-92 \\
\hline & & $\begin{array}{l}\text { Aggressive } \\
\text { chemicnl attack }\end{array}$ & $\begin{array}{l}\text { Limit exposure of above-ground } \\
\text { surfnces to aggressive ground } \\
\text { water to intermittent periods. } \\
\text { Periodically inspect accessible } \\
\text { below-grade surfnces. Perform } \\
\text { plant-specific evaluation of } \\
\text { inaccessible below-grade surfnces. }\end{array}$ & $\begin{array}{l}\text { ACI 349-90; ACl } 207 \\
\text { 3R-79; Regulatory } \\
\text { Guide } 1.127\end{array}$ \\
\hline \multirow{3}{*}{$\begin{array}{l}\text { Fuel storage facility. Refueling canal } \\
\text { GROUP } 6 \\
\text { Intake structure. Cooling tower. Sprny } \\
\text { pond } \\
\text { GROUP } 7 \\
\text { Concrete tanks } \\
\text { GROUP } 9 \\
\text { BWR unit vent stack } \\
\text { GROUP } 8 \\
\text { Steel tanks }\end{array}$} & & $\begin{array}{l}\text { Reaction with } \\
\text { aggregates }\end{array}$ & $\begin{array}{l}\text { Ensure aggregate meets } \\
\text { specifications. }\end{array}$ & $\begin{array}{l}\text { ASTM C227-90; } \\
\text { ASTM C295-90; ACI } \\
201.2 \mathrm{R}-92\end{array}$ \\
\hline & & $\begin{array}{l}\text { Restraint; } \\
\text { Shrinkage; Creep: } \\
\text { Aggressive } \\
\text { environment }\end{array}$ & $\begin{array}{l}\text { Identify masonry walls in close } \\
\text { proximity to, or hnving } \\
\text { attachments from. safety-related } \\
\text { piping or equipment, and } \\
\text { reevaluate design adequacy and } \\
\text { construction practices; and } \\
\text { perform plant-specific corrective } \\
\text { actions. }\end{array}$ & $\begin{array}{l}\text { IE Bulletin 80-11; } \\
\text { Information Notice } \\
87-67\end{array}$ \\
\hline & & Settlement & $\begin{array}{l}\text { Monitor settlement during con- } \\
\text { struction, and continue monitoring } \\
\text { during operation for sites with soft } \\
\text { soil and/or significant changes in } \\
\text { ground water conditions. }\end{array}$ & $\begin{array}{l}\text { Circular } 81-08 \\
\text { Regulatory Guide } \\
1.132\end{array}$ \\
\hline $\begin{array}{l}\text { GROUP } 6 \\
\text { Intake structure, Cooling tower, Sprny } \\
\text { pond }\end{array}$ & $\begin{array}{l}\text { Concrete: F, ExA, ExB, } \\
\text { and InS }\end{array}$ & $\begin{array}{l}\text { Abrasion and } \\
\text { cavitation }\end{array}$ & $\begin{array}{l}\text { Periodic inspections. not to exceed } \\
\text { 5-year intervals. including engi- } \\
\text { neering data compilation and } \\
\text { inspection and evaluation of con- } \\
\text { crete surfaces., structural cracking. } \\
\text { and water passage }\end{array}$ & $\begin{array}{l}\text { Regulatory Guide } \\
1.127\end{array}$ \\
\hline All Groups & $\begin{array}{l}\text { Concrete with embedded } \\
\text { or reinforcing carbon steel }\end{array}$ & $\begin{array}{l}\text { Corrosion of } \\
\text { embedded steel }\end{array}$ & $\begin{array}{l}\text { Ensure concrete of above-ground } \\
\text { surfaces exposed to ground water } \\
\text { meets specifications. Visual } \\
\text { inspection of accessible exterior } \\
\text { walls below ground water table to } \\
\text { determine if management of } \\
\text { ground water and degnuiation of } \\
\text { concrete is required }\end{array}$ & $\begin{array}{l}\text { ACl 349-90; ACl } 207 \\
3 \mathrm{R}-79\end{array}$ \\
\hline $\begin{array}{l}\text { GROUP } 5 \\
\text { Fuel storage facility. Refueling canal }\end{array}$ & Stainless steel liner & $\begin{array}{l}\text { Corrosion of stain- } \\
\text { less steel liner }\end{array}$ & $\begin{array}{l}\text { Leakage detection and inventory } \\
\text { monitoring. and repair }\end{array}$ & \\
\hline $\begin{array}{l}\text { GROUP } 6 \\
\text { Intnke structure. Cooling tower, Spray } \\
\text { pond }\end{array}$ & Structural steel & $\begin{array}{l}\text { Corrosion of } \\
\text { structural steel }\end{array}$ & $\begin{array}{l}\text { Periodic inspections, not to exceed } \\
\text { 5-year intervals. including engi- } \\
\text { neering data compilation and } \\
\text { inspection and evaluation of con- } \\
\text { crete surfaces, structural cracking, } \\
\text { and water passage }\end{array}$ & $\begin{array}{l}\text { Regulatory Guide } \\
1.127\end{array}$ \\
\hline $\begin{array}{l}\text { 'Component types are as follows: Concrete } \\
\text { mterior concrete walts including columns (I } \\
\text { components include columns, baseplates, be } \\
\text { 'With embedded reinforcing cnrbon steel. }\end{array}$ & $\begin{array}{l}\text { atuon } \\
\text { interior concre } \\
\text { ginders, trusse }\end{array}$ & $\begin{array}{l}\text { (F), exterior } \mathrm{c} \\
\mathrm{g} \text { beams (InS) } \\
\text { and jet imping }\end{array}$ & $\begin{array}{l}\text { bove grade (ExA), exterior col } \\
\text { rior concrete structures above } \\
\text { arriers for Groups } \mathbf{1 - 4}\end{array}$ & $\begin{array}{l}\text { below grade }(\mathrm{ExB}) \\
\text { (lnA). Structural steel }\end{array}$ \\
\hline
\end{tabular}




\subsection{References}

10 CFR 50. U.S. Code of Federal Regulations. 1989. "Appendix J: Primary Reactor Containment Leakage Testing for Water-Cooled Power Reactors." U.S. Nuclear Regulatory Commission, Washington, D.C.

American Concrete Institute (ACI) 201.2R-92. 1992 "Guide to Durable Concrete," American Concrete Institute, Detroit.

American Concrete Institute (ACI) 207 3R-79. Revised 1985. "Practices for Evaluation of Concrete in Existing Massive Structures for Service Condition." American Concrete Institute. Detroit.

American Concrete Institute (ACI) 210R-92. 1992 "Erosion of Concrete in Hydraulic Structures." American Concrete Institute. Detroit.

American Concrete Institute (ACI) 222R-85. 1985 "Corrosion of Metals in Concrete." American Concrete Institute, Detroit.

American Concrete Institute (ACI) 318-92. 1992 "Building Code Requirements for Reinforced Concrete." American Concrete Institute, Detroit.

American Concrete Institute (ACI) 349-90. 1990 "Code Requirements for Nuclear Safety Related Concrete Structures." American Concrete Institute, Detroit.

American National Standards Institute/American Institute of Steel Construction (ANSI/AISC) N690. 1994 "Nuclear Facilities - Steel Safety-Related Structure for Design, Fabrication, and Erection." American Institute of Steel Construction, Chicago.

American Society of Mechanical Engineers (ASME) Boiler and Pressure Vessel Code, Section III, Division 2. 1992 Code for Concrete Reactor Vessel and Containments, Subsection CC, "Concrete Containments, "1992 Edition. American Society of Mechanical Engineers, New York.

American Society of Mechanical Engineers (ASME) Boiler and Pressure Vessel Code, Section XI. 1992 Rules for InService Inspection of Nuclear Power Plant Components, 1992 Edition with 1992 Addenda. American Society of Mechanical Engineers, New York.

American Society of Testing and Materials (ASTM) C227-90. 1990 "Test Method for Potential Alkali Reactivity of Cement-Aggregate Combination." American Society of Testing and Materials, Philadelphia.

American Society of Testing and Materials (ASTM) C260-94. 1994 "Standard Specification for Air Entraining Admixtures for Concrete." American Society for Testing and Materials, Philadelphia.

American Society of Testing and Materials (ASTM) C295-90. 1990 "Standard Guide for Petrographic Examination of Aggregates for Concrete." American Society of Testing and Materials, Philadelphia.

Bowles, J.E. 1988. Foundation Analysis and Design, Fourth Edition. McGraw-Hill, New York.

Circular No. 81-08: "FOUNDATION MATERIALS". May 29, 1981. United States Nuclear Regulatory Commission Office of Inspection and Enforcement, Washington, D. C. 20555

Clauss, D.B. August 1989. Severe Accident Testing of Electrical Penetration Assemblies. NUREG/CR-5334 (SAND890327), Sandia National Laboratories, , New Mexico.

Daye, M.A. 1987. "Pressurized Water Reactor Containments and Basemats." In Residual Life Assessment of Major Light Water Reactor and Components - Overview Volume 1, eds. V. N. Shah and P. E. MacDonald. NUREG/CR-4731 (EGG2469), Volume 1, pp. 32-54, prepared by Bechtel National under contract to EG\&G Idaho, Inc. for U.S. Nuclear Regulatory Commission, Washington, D.C.

Electric Power Research Institute (EPRI) NP-3765. 1984. "Surveillance of LWR Spent Fuel in Wet Storage." Electric Power Research Institute, Palo Alto, California. 
Electric Power Research Institute (EPRI) NP-4561. 1986. "Fuel and Pool Component Performance in Storage Pools." Electric Power Research Institute, Palo Alto, California.

IE Bulletin 80-11. May 9, 1980. Masonry Wall Design. U.S. Nuclear Regulatory Commission, Washington, D.C.

Jacobus, M.J. 1990. Aging of Cables, Connections, and Electrical Penetration Assemblies Used in Nuclear Power Plants.

NUREG/CR-5461, Sandia National Laboratories, Albuquerque. New Mexico.

Kassir, M.R., R.X. Bandyopadhyay, and M. Reich. 1993. Thermal Degradation of Concrete in the Temperature Range from Ambient to $315^{\circ} \mathrm{C}\left(600^{\circ} \mathrm{F}\right)$. BNL-52384, Brookhaven National Laboratory, Upton, New York.

Iee, J.K., and Z.S. Szklarska-Smulowska. 1988. "Stress Corrosion Cracking of Sensitized AISI 304 Stainless Steel in Aqueous Chloride Solutions Containing Sulfur at 50 Through 2000 C," Corrosion, 44(8):560.

Mehta, P.R. 1986. Concrete Structures, Properties, and Materials. Prentice-Hall, Inc., New York.

Shah, V.N., R.W. Garner, and D.A. Conley. 1989. "Boiling Water Reactor Containments. " In Residual Life Assessment of Major Light Water Reactor and Components - Overview Volume 2, eds. V.N. Shah and P.E. MacDonald. NUREG/CR-4731 (EGG-2469), Volume 2, pp. 169-207, prepared by EG\&G Idaho, Inc. for the U.S. Nuclear Regulatory Commission, Washington, D.C.

Shah, V.N., and P.E. MacDonald, eds. 1993. Aging and Life Extension of Major Light Water Reactor Components. Elsevier Science Publishers, Amsterdam, The Netherlands.

Shah, V.N., S.K. Smith, and U.P. Sinha. 1994. Insights for Aging management of Light Water Reactor Components, Metal Containments. NUREG/CR-5314 (EG-2562), Volume 5, prepared by EG\&G Idaho, Inc. for the U.S. Nuclear Regulatory Commission Washington, D.C.

Sturrup, V.R, R.D. Horton, P.K. Mukherjee, and T.J. Carmichael. 1987. "Evaluation and Prediction of Concrete Durability - Ontario Hydro's Experience." $A C I$ SP100, 2:1121.

Troxell, G.E., H.E.Davis, and J.W. Kelly. 1968. Composition and Properties of Concrete, Second edition. McGraw-Hill, New York.

U.S. Nuclear Regulatory Commission (NRC) Information Notice 87-67. 1987. Lessons Learned from Regional Inspections of Licensee Actions in Response to IE Bulletin 80-11. U.S. Nuclear Regulatory Commission, Washington, D.C.

U.S. Nuclear Regulatory Commission (NRC) Regulatory Guide 1.127, Rev. 1. March 1978. "Inspection of Water-Control Structures Associated with Nuclear Power Plants." U.S. Nuclear Regulatory Commission, Washington, D.C.

U.S. Nuclear Regulatory Commission (NRC). 1979. Site Investigations for Foundations of Nuclear Power Plants. Regulatory Guide 1.132, Rev. 1, U.S. Nuclear Regulatory Commission, Washington, D.C.

U.S. Nuclear Regulatory Commission (NRC). 1990. Inservice Inspection of Ungrouted Tendons in Prestressed Concrete Containment Structures. Regulatory Guide 1.35, Rev. 3, U.S. Nuclear Regulatory Commission, Washington, D.C. 


\section{Cables, Connectors, and Splices}

This chapter addresses the aging degradation of cables used within the containment of LWRs. The cables are used to transfer energy and signals to operate, monitor, and control the reactor. The cables are used in power, instrumentation, and control applications. This chapter also addresses aging degradation of the cable splices and connectors that are used with the cables.

Cables within nuclear power plants have an excellent performance history for normal plant operating conditions. Based on a review of licensee event report (LER) databases, the number of cable failures is relatively small, and those that occur usually result from handling during installation and maintenance, or from exposure to localized high temperature, radiation, or humidity conditions. The primary safety concern is the performance of aged cable if it is exposed to the harsh environments expected to result from design basis and post design-basis accident conditions.

The principal cable materials, construction, manufacturing, and testing standards are those issued by the Insulated Cable Engineers Association (ICEA) and the National Electrical Manufacturers Association (NEMA). Specific safety cable qualification requirements are contained in 10 CFR 50.49. This rule is based on the Division of Operating Reactors Guidelines (NRC 1979) and NUREG-0588 (NRC 1981). The principal standard for qualification of cables is IEEE Std 323, Standard for Qualifying Class 1 E Equipment for Nuclear Power Generating Stations. The standard for cable testing is IEEE Std 383, Standard for Type Test of Class IE Electric Cables; Field Splices and Connections for Nuclear Power Generating Stations. Regulatory Guides 1.89 and 1.131 apply to the qualification of cables, splices, and connectors. Recently a new voluntary standard, Standard IEEE 1205, Guide for Assessing, Monitoring, and Mitigating Aging Effects on Class 1E Equipment Used in Nuclear Power Generating Stations, was introduced to provide general guidance for aging concerns.

Examples of construction for cables typically used in nuclear power plants are shown in Figure 6.1. The major cable components include the conductor, insulation, shield, and jacket. The cable conductor is typically stranded (many small diameter copper wires clustered together without insulation) or single copper wires insulated from each other in a cluster. While stranded conductors are more susceptible to corrosion (high surfaceto-volume ratio), they are more flexible and less likely to be damaged due to vibration or handling.

Cables and connectors are usually insulated using polymer-based compounds (except for some mineral-insulated cable). The main function of the insulation is to isolate electrical conductors from grounding. In some applications the insulation also serves to maintain high direct current resistivity, low alternating current losses, or proper concentricity of conductor and shield. The most important dielectric properties are breakdown strength and insulation resistance.

The jacket provides protection to the rest of the cable and maintains the vital hermetic sealing of the cable. Jacket materials protect both individual wires and multiconductor cables. There are certain minimum electrical requirements for the jacket; however, the materials are selected primarily on the basis of mechanical, environmental resistance, and firesuppressing properties.

The shield on low-voltage cable serves to isolate circuits from one another and from outside interference. The shield provides a constant circuit electrical impedance and ensures proper transmission of high-frequency or pulse signals. The shield also helps to prevent cable jacket cracks from propagating into the insulation.

Examples of cable splice assemblies are shown in Figure 6.2. Permanent cable splices are used in LWR containments to reduce the number of connection joints that have to be maintained. Splices are used in new plant designs, and they generally have been used to replace terminal strips in the older plants. Splices use crimped wire connectors and waterproof shrink tubing to seal the splice. This design allows use of simplified installation procedures and helps to detect errors during assembly. The splice is designed to maintain continuity of cable component functions and provides an environmental seal. 


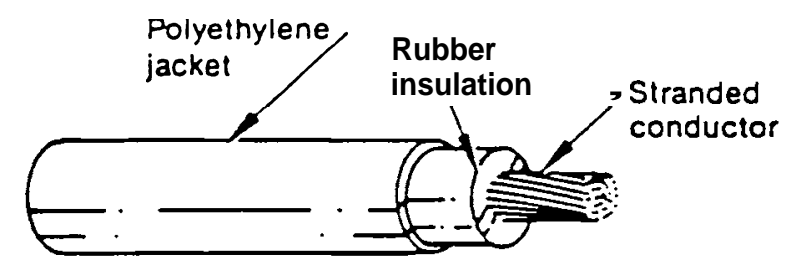

Single stranded conductor power cable.

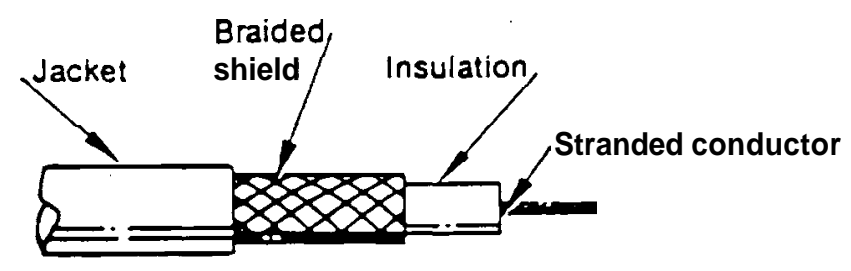

\section{Coaxial instrumentation cable}

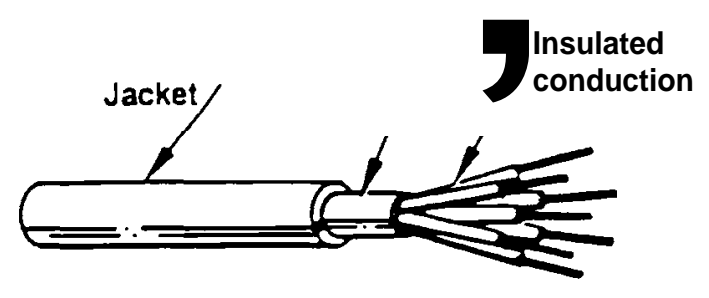

\section{Multiconductor control cable}

Figure 6.1 Examples of cable construction for cables used in nuclear power plants (Gardner and Meyer 1989)

A cable multiconductor connector and its components are illustrated in Figure 6.3. The cable connector is a device located at the cable ends that ensures functional continuity of the cable conductor, insulation, shield, and acket by sealing them from the environment. Usually the connectors are fabricated as mating (pin and sleeve) devices to match in the field. Multiconductor connectors often have outer gasket-type seals and inner seals made of filler compounds or sealing cements that surround the individual conductors. 

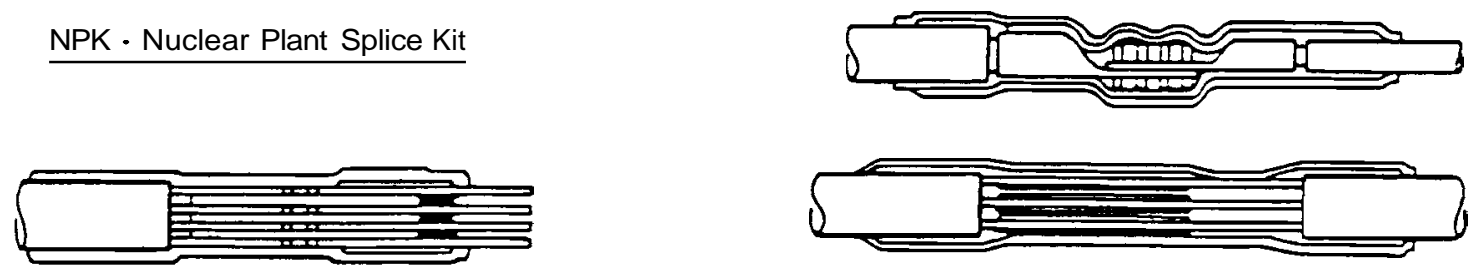

NPKV - Nuclear Plant Stub Connection Kit ("V")

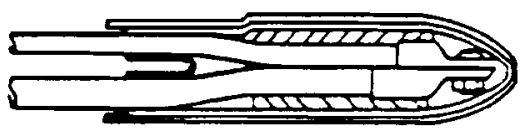

Figure 6.2 Raychem NPK and NPKV splice assemblies (Gardner and Meyer 1989)

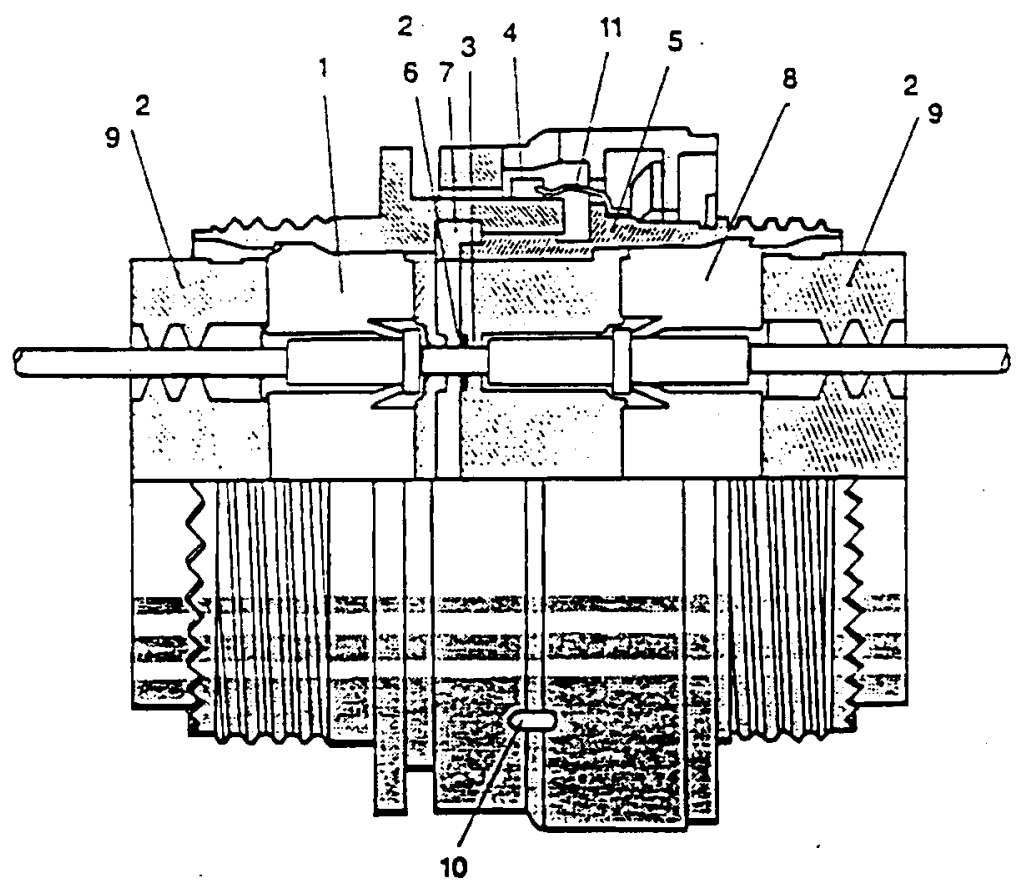

Connector features

1-Molded one-piece contact retention dsc

2-Fluorosilicone fluid resistant

seal material.

3-Closed entry socket insert and contacts.

4-Bayone! coupling system.

5-5 key shell polarization.

6-Intertacial mating seal.

7-Static peripheral shall seal.
8-Monoblock constructioninserts bonded to shells. 9-Sell-sealing rear grommets.

10-Visual mating indicators.

11-Shelf-to-shell grounding fingers.

12-Accepts Mil-C-38999 handware.

13-Conductive shell finish.

Figure 6.3 Amphenol 418 Series multiconductor connector (Gardner and Meyer 1989) 


\subsection{Aging Degradation Concerns and Mechanisms}

The aging degradation concerns and mechanisms for LWR cable materials are summarized in Table 6.1. Materials commonly used for the conductor, shield, insulation, and jacket components are listed in the table. Not all materials nor possible variations in design (e.g., bare or tinned metal structure) are included. The non-metallic materials employ different compounds: adders (like antioxidants), fillers, fire retardants, curing agents, etc.

Table 6.1 Aging degradation concerns and mechanisms for LWR cable materials

\begin{tabular}{|c|c|c|c|c|}
\hline Components & Materials' & Aging Concerns s.' & Aging Mechanisms & References $^{\mathrm{d}}$ \\
\hline \multirow[t]{3}{*}{ Conductors } & Stranded copper & $\begin{array}{l}\text { Conductivity loss; High } \\
\text { surface to area ratio; } \\
\text { Exposure to air and } \\
\text { moisture }\end{array}$ & Medium corrosion & \multirow[t]{3}{*}{ pp. $827-830$} \\
\hline & Solid copper & \multirow{2}{*}{$\begin{array}{l}\text { Conductivity loss; } \\
\text { Exposure to air and } \\
\text { moisture }\end{array}$} & Low corrosion & \\
\hline & $\begin{array}{l}\text { Nickel-plated } \\
\text { copper }\end{array}$ & & Medium corrosion & \\
\hline \multirow{4}{*}{$\begin{array}{l}\text { Shields (on low- } \\
\text { voltage cables) }\end{array}$} & Braided copper & \multirow{4}{*}{$\begin{array}{l}\text { Increased interference and } \\
\text { improper signal trans- } \\
\text { mission; Exposure to air } \\
\text { and moisture }\end{array}$} & Medium corrosion & \multirow{4}{*}{$\begin{array}{l}\text { pp. } 827-830 ; \text { pp. } 850- \\
851\end{array}$} \\
\hline & Tinned copper tape & & Low corrosion & \\
\hline & Aluminum foil & & Medium corrosion & \\
\hline & $\begin{array}{l}\text { Metallized mylar } \\
\text { tape }\end{array}$ & & High corrosion & \\
\hline \multirow[t]{10}{*}{ Insulation and jacket' } & Polyester (unfilled) & \multirow{10}{*}{$\begin{array}{l}\text { Shrinking, creeping, thin- } \\
\text { ning, embrinlement, cross- } \\
\text { linkinglscissioning, and } \\
\text { cracking; Current leaking, } \\
\text { shorting: Aging } \\
\text { acceleration in areas with } \\
\text { high temperature, } \\
\text { radiation, and humidity; } \\
\text { Loss of dielectric } \\
\text { properties }\end{array}$} & Radiation, oxidation, & \multirow{10}{*}{$\begin{array}{l}\text { pp. 827-833; pp. 845- } \\
853\end{array}$} \\
\hline & Nylon & & local hot spots; & \\
\hline & Polyethylene & & absorption and & \\
\hline & Neoprene & & Chemical reactions & \\
\hline & -Eth-lene- ro lene- & & & \\
\hline & Hypalon & & & \\
\hline & XLPE & & & \\
\hline & Butyl rubber & & & \\
\hline & Kapton & & & \\
\hline & Silicone & & & \\
\hline \multicolumn{5}{|c|}{$\begin{array}{l}\text { This is not a complete list of materials used for these components. Variations in design (e.g., bare. or tinned metal structure) are also not } \\
\text { listed. } \\
\text { baging stressors caused by steam condensation and high temperature, pressure, and radiation from a design-basis event are important } \\
\text { concerns. } \\
\text { "Aging of conductors and shields is accelerated by exposure to moisture and air due to damaged jackets and insulation; and defective seals at } \\
\text { splices and connectors. Aging of all components is accelerated by manufacturing defects, installation damage, overload currents, } \\
\text { currentlvoltage surges, movementlflexing during maintenance, vibration, thermal cycling, chemicals from interfaces, surface dust, and } \\
\text { distortion pressures due to sharp bends, thermal expansion rate differences, hot spots, support variations, clamps, etc. } \\
\text { The references are to pages of Shah and MacDonald (1993). } \\
\text { Th e aging rates of insulation and jacket materials have substantial differences between materials and within each material (density, } \\
\text { structure, cross-linkage, etc., variations). }\end{array}$} \\
\hline
\end{tabular}


The principal aging mechanism for conductors is corrosion. The conductor material and design has an effect on the rate of corrosion. The main aging concern of the conductor is exposure to air and moisture (e.g., steam). A high surfaceto-volume ratio for stranded conductors makes them especially susceptible to corrosion. Corrosion of the conductor will increase the resistance at the affected region, reducing cable functional performance, causing local heat generation rates to increase, and ultimately fail the cable. As long as the other cable components, splices, and connectors perform their function to seal the conductors from moisture, the corrosion activity is not likely to occur.

The shield is made of metal, and like conductors, corrosion is the principal aging mechanism. Sealing the shield from moisture and air will prevent corrosion. Corrosion will degrade the shield and lead to increased interference and improper signal transmission between instruments, controls, and measurement devices.

The insulation and jacket are constructed of non-metallic materials that are susceptible to damage from radiation, heat, and oxidation in the harsher local environments of containment. Chemical reactions and moisture and chemical absorption and diffusion are prolific at higher temperatures. Cable movement from pulling, bending, turning, etc., and vibration can also degrade the cables. These mechanisms can all contribute to damage of the jacket and insulation and subsequently the shield and conductor as well. The damage caused to the material is shrinking, creeping, thinning, embrittlement, material crosslinking, scissioning, and cracking. Jacket and insulation failure leads to corrosion of the shield and conductor components, electrical current leakage, and shorting of the cable.

Aging concerns that can directly or indirectly affect all of the components include defective seals at splices and connectors; aging acceleration caused by manufacturing defects, installation damage, overload currents, current/voltage surges, movement 1 flexing of the cable during maintenance, thermal cycling, chemicals from component interfaces, surface dust and dirt, and cable distortion due to sharp bends; component material thermal expansion rate differences, hot spots, support variations, clamps, etc. These aging acceleration mechanisms and concerns will also affect splices and connectors.

The aging degradation concerns and mechanisms for the cable splices are outlined in Table 6.2. The two principal components are the tubinglsealant and crimp. The tubinglsealant is non-metal, and it is subject to the same aging mechanisms and concerns as the cable jacket and insulation described above. It also has the same accelerated aging concerns. The tubinglsealant component is important to prevent moisture and air exposure to the joint and the cable components. The copper crimp component is subject to corrosion if exposed to air and moisture. Corrosion will cause the crimp to increase the resistance at the joint and degrade the cable service functions.

The aging and degradation concerns and mechanisms of the cable connectors are described in Table 6.3. The main aging mechanism of the pin and socket contact components are wear of the gold-plated copper interfaces during connector assembly/ disassembly operations. If exposed, the copper becomes susceptible to corrosion from moisture and air. There is also a

Table 6.2 Aging degradation concerns and mechanisms for $\mathbf{L} \mathbf{W} \mathbf{R}$ cable splices

\begin{tabular}{|c|c|c|c|c|}
\hline Components & Materials & $\begin{array}{c}\text { Aging } \\
\text { Concerns }^{\mathrm{Lb}} \\
\end{array}$ & Aging Mechanisms & References' \\
\hline $\begin{array}{l}\text { Tubing and } \\
\text { sealant }\end{array}$ & WCSF-N & $\begin{array}{l}\text { Cracking and } \\
\text { leakage }\end{array}$ & $\begin{array}{l}\text { Radiation, oxidation, and } \\
\text { thermal damage; Moisture and } \\
\text { chemical absorption and } \\
\text { diffusion; Wear; Chemical } \\
\text { reactions }\end{array}$ & $\begin{array}{l}\text { pp. } 833,834,842 \text {, } \\
853\end{array}$ \\
\hline Crimp & Copper & $\begin{array}{l}\text { Increased } \\
\text { resistance; } \\
\text { Exposure to air } \\
\text { and moisture; } \\
\text { Loosening }\end{array}$ & Corrosion; Thermal cycling & $\begin{array}{l}\text { pp. } 833,835,838- \\
842,850,851,853\end{array}$ \\
\hline \multicolumn{5}{|c|}{$\begin{array}{l}\text { 'Aging stressors caused by steam condensation and high temperature, pressure, and radiation from a design-basis even } \\
\text { are important concerns. } \\
\text { bAging of splices is accelerated by exposure to moisture and air, overload currents, current/voltage surges, movement } \\
\text { flexing during maintenance, vibration, thermal cycling, chemicals from interfaces, surface dust, and distortion } \\
\text { pressures due to sharp turns, thermal expansion rate differences, hot spots, support variations, clamps, etc. } \\
\text { Th e references are to pages of Shah and MacDonald } 1993 \text {. }\end{array}$} \\
\hline
\end{tabular}


Table 6.3 Aging degradation concerns and mechanisms of LWR cable connectors

\begin{tabular}{|c|c|c|c|c|}
\hline Components & Materials" & Aging Concerns s'.' & Aging Mechanisms & References $^{\mathrm{d}}$ \\
\hline Pin and socket contacts & $\begin{array}{l}\text { Gold-plated } \\
\text { copper }\end{array}$ & $\begin{array}{l}\text { Loss of } \\
\text { conductivity; } \\
\text { Increased resistance }\end{array}$ & $\begin{array}{l}\text { Wear with use; corrosion; gold- } \\
\text { solder interaction }\end{array}$ & \multirow[t]{7}{*}{$\begin{array}{l}\text { pp. 833, 834, 842, 843, } \\
851,863-866\end{array}$} \\
\hline Hood & Stainless steel & -- & -- & \\
\hline Shell; Coupling ring & Aluminum & -- & -- & \\
\hline $\begin{array}{l}\text { Retention disc and } \\
\text { inserts }\end{array}$ & $\begin{array}{l}\text { Thermoplastic } \\
\text { polymer }\end{array}$ & $\begin{array}{l}\text { Material } \\
\text { degradation }\end{array}$ & $\begin{array}{l}\text { Wear with use; radiation, } \\
\text { thermal, and oxidation damage }\end{array}$ & \\
\hline Grommets and seals & $\begin{array}{l}\text { Fluorosilicone } \\
\text { elastomers }\end{array}$ & $\begin{array}{l}\text { Cracking; leaking } \\
\text { air and moisture }\end{array}$ & $\begin{array}{l}\text { Radiation, thermal, and } \\
\text { oxidation damage; moisture } \\
\text { absorption; wear }\end{array}$ & \\
\hline Bayonet rivets & Stainless steel & -- & -- & \\
\hline $\begin{array}{l}\text { Finish (shells and } \\
\text { coupling ring) }\end{array}$ & $\begin{array}{l}\text { Cadmium plate } \\
\text { over nickel }\end{array}$ & -- & -- & \\
\hline \multicolumn{5}{|c|}{$\begin{array}{l}\text { This is not a complete list of materials used for these components. } \\
\text { "Aging caused by steam condensation and high temperature, pressure, and radiation from a design-basis event are important concerns. } \\
\text { "Aging of connectors is accelerated by seals being exposed to moisture and air. Aging of all components is accelerated by overload currents, } \\
\text { current/voltage surges, movementlflexing during maintenance. vibration, thermal cycling, chemicals from interfaces, distortion pressures due } \\
\text { to sharp turns, thermal expansion rate differences, hot spots, support variations, etc. } \\
\text { oThe references are to pages of Shah and MacDonald 1993. }\end{array}$} \\
\hline
\end{tabular}

potential of gold solder interaction. A loss of good contact in the connector will cause a loss of conductivity through the joint and increase the resistance to degrade the cable performance. The retention disc/insert and grommets/seal components are susceptible to the aging mechanisms of radiation, oxidation, and thermal damage like other non-metals in the cable system. They also are subject to wear during assembleldisassembly operations. The materials can also be degraded by moisture and chemical activity. It is important for these components to maintain their integrity to prevent moisture and air migration to the cable ends at the joint.

\subsection{Managing Aging Degradation}

The options for managing aging degradation of LWR cables, splices, and connectors are summarized in Tables 6.4, 6.5, and 6.6, respectively. The management options are similar for all three items and their components.

In Table 6.4, the cable aging management options include a basic monitoring of local environmental radiation and temperature "hot spots" within containment. Special focus should be given to monitoring cables that are located in or near the environmental "hot spots" and other known cable high stress areas (e.g, cable turns, clamps, heavy condensation regions).

Examples of typical areas to monitor are where cables pass through fire stops, areas in terminal boxes where cables are heated by their connection to high-temperature equipment, high humidity and steam exposure areas, and areas in narrow passages that contain both hot piping and cables. Routine visual and infrared survey examinations of open runs, terminal areas, and areas of known local high stressors provide a good means to detect abuse or aging degradation. Insulation resistance tests and cable indenter (currently in advanced development) tests can also be periodically performed and trended in those type of areas. Other nondestructivecable condition monitoring equipment has been under development and should be observed for the eventual availability of practical equipment. It is important to maintain records on inspections and tests performed on cables, splices, and connectors. Failures should be analyzed, and corrective action must be taken. It is important for operations and maintenance staff to be trained in how to monitor and handle cables, splices, and connectors. All of the management options discussed in this paragraph apply to cable splices and connectors as well. 
Table 6.4 Managing aging degradation of LWR cable materials

\begin{tabular}{|c|c|c|c|c|}
\hline Components & Materials & $\begin{array}{c}\text { Aging } \\
\text { Mechanisms } \\
\end{array}$ & Management Options & References' \\
\hline \multirow[t]{3}{*}{ Conductors } & Stranded copper & Medium corrosion & \multirow{17}{*}{$\begin{array}{l}\text { Perform periodic visual inspection and } \\
\text { insulation resistance and cable indenter tests } \\
\text { in areas of known high local stress; monitor } \\
\text { containment temperature and radiation hot } \\
\text { spots where cables are located; monitor for } \\
\text { hot spots (infrared survey) and defective } \\
\text { seals at cable splices, connectors, and } \\
\text { terminals; minimize cable disturbance; keep } \\
\text { connectors and terminals clean and dry; } \\
\text { perform record keeping, staff training, and } \\
\text { failure analysis; use condition monitoring } \\
\text { equipment when it is sufficiently developed } \\
\text { and is practical. }\end{array}$} & \multirow{17}{*}{$\begin{array}{l}\text { pp. 854-869; } \\
\text { IEEE } 1205\end{array}$} \\
\hline & Solid copper & Low corrosion & & \\
\hline & $\begin{array}{l}\text { Nickel-plated } \\
\text { copper }\end{array}$ & Medium corrosion & & \\
\hline \multirow{4}{*}{$\begin{array}{l}\text { Shields (on } \\
\text { low-voltage } \\
\text { cables) }\end{array}$} & Braided copper & _Medium_corrosion_ & & \\
\hline & Tinned copper tape & Low corrosion & & \\
\hline & Aluminum foil & Medium corrosion & & \\
\hline & $\begin{array}{l}\text { Metallized mylar } \\
\text { tape }\end{array}$ & High corrosion & & \\
\hline \multirow{10}{*}{$\begin{array}{l}\text { Insulation and } \\
\text { jacket }\end{array}$} & Polyester (unfilled) & \multirow{10}{*}{$\begin{array}{l}\text { Radiation, } \\
\text { oxidation, and } \\
\text { thermal damage; } \\
\text { Moisture and } \\
\text { chemical absorp- } \\
\text { tion and diffusion; } \\
\text { Wear; Chemical } \\
\text { reactions }\end{array}$} & & \\
\hline & Nylon & & & \\
\hline & Polyethylene & & & \\
\hline & Neoprene & & & \\
\hline & Ethylene propylene & & & \\
\hline & Hypalon & & & \\
\hline & XLPE & & & \\
\hline & Butyl rubber & & & \\
\hline & Kapton & & & \\
\hline & Silicone & & & \\
\hline
\end{tabular}

In Table 6.5 the management options for cable connectors are, in general, the same as for the cables themselves. While the splices are being made it is important to keep the components dry and clean. It is important to minimize the movement of the splices. The splices can be monitored during the routine visual and infrared inspection of the cables.

The aging management options in Table 6.6 focus on maintenance to keep the connectors clean and dry. The assembly, disassembly, and handling operations should be minimized to keep the contacts from being worn excessively. The components of the connectors need to be inspected during the assembly/disassembly process to ensure that the contact and sealing integri-ties are maintained. The connectors should be routinely monitored by visual and infrared inspection along with the cables and splices.

Table 6.5 Managing aging degradation of LWR cable splices

\begin{tabular}{|c|c|c|c|c|}
\hline Components & Materials & Aging Mechanisms & Management Options & References \\
\hline $\begin{array}{l}\text { Tubing and } \\
\text { sealant }\end{array}$ & WCSF-N & $\begin{array}{l}\text { Radiation, oxidation, and thermal } \\
\text { damage; Moisture and chemical } \\
\text { absorption and diffusion; Wear; } \\
\text { Chemical reactions }\end{array}$ & \multirow[t]{2}{*}{$\begin{array}{l}\text { Monitor splices for hot spots } \\
\text { by infrared survey; Periodic } \\
\text { visual inspection; Minimize } \\
\text { cable disturbance; Staff } \\
\text { training }\end{array}$} & \multirow[t]{2}{*}{$\begin{array}{l}\text { pp. } 856,866 \\
\text { (Shah and } \\
\text { MacDonald } \\
\text { 1993) }\end{array}$} \\
\hline Crimp & Copper & Corrosion & & \\
\hline
\end{tabular}


Table 6.6 Managing aging degradation of LWR cable connectors

\begin{tabular}{|c|c|c|c|c|}
\hline Components & Materials" & Aging Mechanisms & Management Options & References \\
\hline Pin and socket contacts & Gold-plated copper & $\begin{array}{l}\text { Wear with use; } \\
\text { Corrosion; Gold-solder } \\
\text { interaction }\end{array}$ & \multirow{7}{*}{$\begin{array}{l}\text { Minimize disturbance; } \\
\text { Monitor for hot spots by } \\
\text { infrared survey; Monitor } \\
\text { seals; Periodic visual } \\
\text { inspection; Keep clean and dry } \\
\text { (especially when connecting in } \\
\text { moist areas); Staff training }\end{array}$} & \multirow{7}{*}{$\begin{array}{l}\text { pp. 842, 843,851, } \\
853, \mathbf{8 5 5}, \mathbf{8 5 6 , 8 6 3} \\
\text { (Shah and } \\
\text { MacDonald 1993) }\end{array}$} \\
\hline Hood & Stainless steel & -- & & \\
\hline Shell; Coupling ring & Aluminum & -- & & \\
\hline $\begin{array}{l}\text { Retention disc and } \\
\text { inserts }\end{array}$ & Thermoplastic polymer & $\begin{array}{l}\text { Wear with use; Radia- } \\
\text { tion, thermal, and } \\
\text { oxidation damage }\end{array}$ & & \\
\hline Grommets and seals & $\begin{array}{l}\text { Fluorosilicone } \\
\text { elastomers }\end{array}$ & $\begin{array}{l}\text { Radiation. thermal, and } \\
\text { oxidation damage; Mois- } \\
\text { ture absorption; Wear }\end{array}$ & & \\
\hline Bayonet rivets & Stainless steel & -- & & \\
\hline $\begin{array}{l}\text { Finish (shells and } \\
\text { coupling ring) }\end{array}$ & $\begin{array}{l}\text { Cadmium plate over } \\
\text { nickel }\end{array}$ & -- & & \\
\hline
\end{tabular}

\subsection{References}

10 CFR 50.49. U.S. Code of Federal Regulations. 1988. "Environmental Qualification of Electric Equipment Important to Safety for Nuclear Power Plants." U.S. Nuclear Regulatory Commission, Washington, D.C.

Gardner, J.B., and L.C. Meyer. 1989. "Pressurized Water Reactor and Boiling Water Reactor Cables and Connections in Containment." In Residual Life Assessment of Major Light Water Reactor Components - Overview Volume 2, eds., V.N. Shah and P.E. MacDonald. NUREG/CR-4731 (EGG-2469) Volume 2, pp. 300-329, prepared by EG\&G Idaho, Inc. for the U.S. Nuclear Regulatory Commission, Washington, D.C.

Institute of Electrical and Electronics Engineers (IEEE) Std 323. 1983 (Reaffirmed 1990). Standard for Qualifying Class $1 E$ Equipment for Nuclear Power Generating Stations. Institute of Electrical and Electronics Engineers, New York.

Institute of Electrical and Electronics Engineers (IFFEF) Std 383. 1974 (Reaffirmed 1992). Standard for Type Test of Class IE Electric Cables; Field Splices and Connections for Nuclear Power Generating Stations. Institute of Electrical and Electronics Engineers, New York.

Institute of Electrical and Electronics Engineers (IEEE) 1205. 1993. Guide for Assessing, Monitoring, and Mitig ati $n$ g Aging Effects on Class IE Equipment Used in Nuclear Power Generating Stations. Institute of Electrical and Electronics Engineers, New York.

Shah, V.N., and P.E. MacDonald, eds. 1993. Aging and Life Extension of Major Light Water Reactor Components. Elsevier Publishing, New York.

U.S. Nuclear Regulatory Commission (NRC). 1977. Qualification Tests of Electric Cables, Field Splices, and Connections for Light-water-cooled Nuclear Power Plants. Regulatory Guide 1.131, Rev. 0, U.S. Nuclear Regulatory Commission, Washington, D.C.

U.S. Nuclear Regualtory Commission (NRC). 1979. "Division of Operating Reactors (DOR) Guidelines." U.S. Nuclear Regulatory Commission, Washington, D.C. 
U.S. Nuclear Regualtory Commission (NRC). 1981. Interim Staff Position on Environmental Qualification of Safely-Related Elecrrical Equipment: Including Staff Responses to Public Comments. NUREG-0588, Rev. 1, U.S. Nuclear Regulatory Commission, Washington, D.C.

U.S. Nuclear Regulatory Commission (NRC). 1984. Environmental Qualification of Cerrain Electric Equipment Important to Safety for Nuclear Power Plants. Regulatory Guide 1.89, Rev. 1, U.S. Nuclear Regulatory Commission, Washington, D.C. 


\section{Distribution}

No. of

Conies

\section{OFESITE}

21 U.S. Nuclear Regulatory Commission Washington, D.C. 20555

ATTN: S.K. Shaukat (20)

$$
\text { J.P. Vora }
$$

R.L. Lofaro

Brookhaven National Laboratory

Upton, NY 11973

B. Poole

Oak Ridge National Laboratory

P.O. Box 2009

Oak Ridge, TN 37831

L. Magelby

Idaho National Engineering Laboratory P.O. Box 1675

Idaho Falls, ID 83415
No. of

Conies

S.P. Nowlen

Sandia National Laboratory

P.O. Box 5800

Albuquerque, NM 87185

ONSITE

DOE Richland Operations Office

D.C. Langstaff

K8-50

24 Pacific Narthwest I aboratory

M.E. Cunningham K8-43

R.D. Orton K8-33

J.V. Livingston (10) K8-37

A.B. Johnson K8-34

G.D. Springer K8-34

Technical Report Files (10) 